ANL-4409-1

Distribution Category UC-94d

\title{
ECONOMICS AND MARKET POTENTIAL OF HYDROGEN PRODUCTION
}

September 1978

Prepared by

Hittman Associates, Inc.

Columbia, Maryland 21045

United States Department of Energy

Assistant Secretary, Energy Technology

Division of Energy Storage. Systems

Washington, D.C. 20545

Under Contract 31-109-38-4409 


\section{DISCLAIMER}

This report was prepared as an account of work sponsored by an agency of the United States Government. Neither the United States Government nor any agency Thereof, nor any of their employees, makes any warranty, express or implied, or assumes any legal liability or responsibility for the accuracy, completeness, or usefulness of any information, apparatus, product, or process disclosed, or represents that its use would not infringe privately owned rights. Reference herein to any specific commercial product, process, or service by trade name, trademark, manufacturer, or otherwise does not necessarily constitute or imply its endorsement, recommendation, or favoring by the United States Government or any agency thereof. The views and opinions of authors expressed herein do not necessarily state or reflect those of the United States Government or any agency thereof. 


\section{DISCLAIMER}

Portions of this document may be illegible in electronic image products. Images are produced from the best available original document. 


\section{ACKNOWLEDGMENTS}

This report is a product of the joint efforts of staff from Hittman Associates, the U.S. Department of Energy Division of Energy Storage Systems, Chem Systems, Inc, EPRI, and SRI International. Participating staff from Hittman Associates included $\mathrm{Mr}$. William Scherkenbach, who served as program manager; Dr. Donald Dohrmann, principal author of the report; and $\mathrm{Mr}$. Lawrence Taylor, contributor. included:

Participating staff from the U.S. Department of Energy

Dr. James Swisher

Dr. Beverly Berger.

Participating staff from EPRI and SRI International included, respectively:

Dr. A. Fickett

Dr. E. Dickson.

Hittman Associates would like to acknowledge the cooperation and support of all team members. 
TABLE OF CONTENTS

$\underline{\text { Page }}$

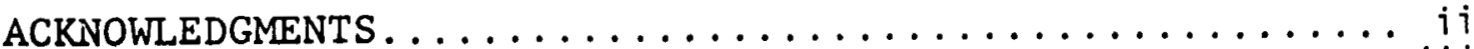

TABLE OF CONTENTS ......................

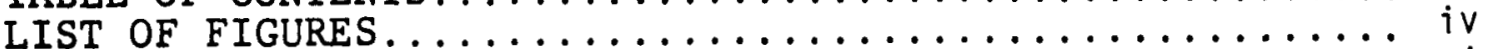

LIST OF TABLES ........................ vi

ECONOMIC AND MARKET POTENTIAL OF HYDROGEN PRODUCTION.... 1

EXECUTIVE SUMMARY $\ldots \ldots \ldots \ldots \ldots \ldots \ldots \ldots \ldots \ldots$

Conclusions of the study................. 1

Summary of Analysis...................... 3

I. INTRODUCTION ..................... I

A. Scope of study..................... I-I

B. Sources of Data..................... I-1

C. Methodology........................ I-2

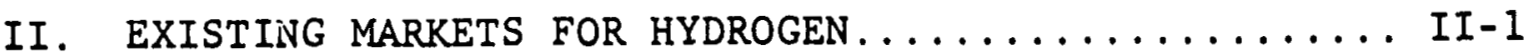

A. Hydrogen in Ammonia Synthesis............. II-I

B. Hydrogen in Methanol Production............. II-7

C. Hydrogen in Petroleum Refining............. II-12

D. Specialty Uses of Hydrogen................ II-19

E. Probable Market Growth................ II-22

REFEREINCES - Chapter II ................. II-24

III. ECONOMICS OF HYDROGEN PRODUCTION.............. III-I

A. Hydrogen Froduction from Natural Gas......... III-1

B. Hydrogen Pzoduction Through Coal Gasi-

fication. . ......................... III 4

C. Electrolytic Production of Hydrogen......... III-23

D. Comparison of Alternative Technologies........ III-41

REFERENCES - Chapter III.................... III-46

IV. PROSPECTIVE MARKETS FOR HYDROGEN $\ldots \ldots \ldots \ldots \ldots \ldots$ IV-I

A. Identification of Possible Uses............ IV-1

B. Captive Uses of Hydrogen................ IV-2

C. Fuel Applications of Hydrogen............. IV-6

REFERENCES - Chapter IV.................. VI-9 
LIST OF FIGURES

Figure

$\underline{\text { Page }}$

1 Hydrogen Use in Chemical Applications........ I

2 Comparative Costs of Producing Hydrogen

Steam-Methane Reforming vs. Coal Gasification,

$1980 \$ \ldots \ldots \ldots \ldots \ldots \ldots \ldots \ldots \ldots \ldots \ldots \ldots$. . . . . . . . . . . .

3 Hydrogen Production Costs Natural Gas Reforming vs. "New" Gasification - 100

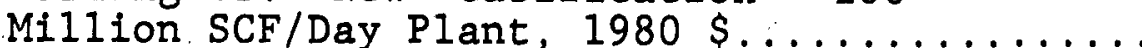

4 Comparative Costs of Hydrogen through Coal

Gasification Equity vs. Utility Financing, $1980 \$$

5 Comparative Costs of Producting Hydrogen Advanced Electrolysis vs. Natural Gas Reforming - $1980 \$$

6 Comparative Costs of Producing Hydrogen by Natural Gas Reforming, Advanced Electrolysis, "New" Coal Gasification, $1980 \$ \ldots \ldots \ldots \ldots \ldots$.

7 Geographical Locations of Coal and Nuclear Resources for Hydrogen Production............

III-1 Hydrogen Production Processes: (a) Steam Reforming (b) Partial Oxidation of Residual 0il

(c) Partial Oxidation of Coal...............II-2

III-2 Comparative Cost of Producing Hydrogen SteamMethane Reforming vs. Coal Gasification,

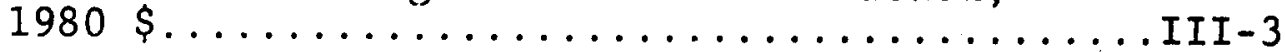

III-3 Hydrogen Production Costs Natural Gas Reforming vs. "New" Coal Gasification - 100 Miliion SCF/Day Plant, $1980 \$ \ldots \ldots \ldots \ldots \ldots \ldots$ III-13

III-4 Hydrogen Production Costs Natural Gas Reforming vs. "New" Gasification - 100 Million SCF/Day Plant, $1980 \$ \ldots \ldots \ldots \ldots \ldots \ldots \ldots$. . III-15

III-5 Ammonia Production Costs Natural Gas Reforming vs. "New" Coal Gasification - 2,000 ST/Day

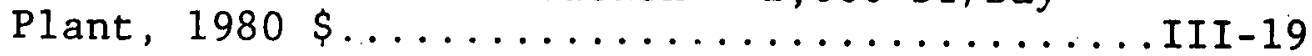

III-6 Methanol Production Costs Natural Gas Reforming vs. "New" Coal Gasification - 2,000 ST/Day Plant, $1980 \$ \ldots \ldots \ldots \ldots \ldots \ldots \ldots \ldots$ III-20 


\section{LIST OF FIGURES (Continued)}

Figure

Page

III-7 Comparative Costs of Hydrogen Through Coal Gasification Equity vs. Utility Financing, 1980

III-8 Comparative Costs of Producing Hydrogen Advanced Electrolysis vs. Natural Gas Reforming, $1980 \$ \ldots \ldots \ldots \ldots \ldots \ldots \ldots \ldots \ldots$ III -40

III-9 Comparative Costs of Producing Hydrogen by Natural Gas Reforming, Advanced Electrolysis, "New" Coal Gasification, $1980 \$ \ldots . \ldots \ldots \ldots$ III-44

III-10 Geographical Locations of Coal and Nuclear Resources for Hydrogen Production........... III-45 


\section{LIST OF TABLES}

Table

$\underline{\text { Page }}$

II-1 PROJECTIONS OF HYDROGEN USE IN AMMONIA

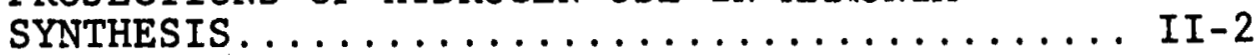

II-2 PROJECTIONS OF HYDROGEN USE IN METHANOL PRODUCTION . . . . . . . . . . . . . . . . II 8

II-3 PROJECTIONS OF HYDROGEN USE IN PETROLEUM REFINING. . ....................... II 13

II-4 U.S. REFINERY HYDROGEN REOUIREMENTS. . . . . . II-17

II-5 HYDROGEN REQUIREMENTS FOR HYDROTREATING...... II-17

II-6 PROJECTIONS OF HYDROGEN USE IN SPECIALTY

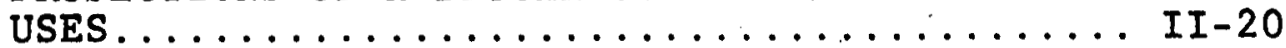

II-7 HYDROGEN USE IN CHEMICAL APPLICATIONS ...... II-23

III-1 COAL GASIFICATION PROCESSES FOR HYDROGEN PRODUCTION OPERATING CHARACTERISTICS........ III-5

III-2 ESTIMATES OF THE COST OF HYDROGEN FROM COAL.. III-9

III-3 PROJECTIONS OF NATURAL GAS PRICES $\$ / M C F \ldots . .$. III-11

III-4 PROJECTIONS OF COAL PRICES ............ III-16

III-5 ESTIMATES OF COST OF PRODUCING HYDROGEN THROUGH ELECTROLYSIS . ................ III-27

III-6 U.S. NATURAL GAS PRODUCTION............ III-42

III-7 U.S. USE OF GAS .................. III-42

IV-1 SUMMARY OF HYDROGEN FORECASTS SYNTHETIC FUELS . . . . . . . . . . . . . . . . . . . . IV 3 


\section{EXECUTIVE SUMMARY}

A study was undertaken to evaluate the economics of producing hydrogen from coal and from water and to assess the market potential for this hydrogen in chemical and fuel applications. Results of this study are summarized here.

\section{Conclusions of the Study}

- Current chemical applications of hydrogen in manufacturing ammonia and methanol, in refining petroleum and in specialty uses provide a base market for penetration by new hydrogen production technologies, although prospects for the use of hydrogen in fuel applications remain unclear. Accelerating the penetration of new hydrogen production technologies into existing markets based on chemical applications could provide a learning experience which would enhance the probabilities for use of these technologies in fuel applications.

- Electrolysis and coal gasification will be complementary, not competitive, technologies for producing hydrogen. Coal gasification plants are better suited to production of large quantities of hydrogen, while electrolyzers are better suited to the production of hydrogen for small scale uses. Moreover, electrolysis might prove attractive in the Northeast and in the West where the availability of nuclear and hydro power can compensate for the lack of coal resources.

- Hydrogen produced through coal gasification may be economical in chemical applications (e.g., ammonia production) by the late 1990 's. Development programs now underway are expected to provide new coal gasification technologies with lower first costs and higher efficiencies than current technologies. In addition, natural gas prices are projected to increase more rapidiy than coal prices. Rates of increase projected for natural gas prices (in constant dollars) fall in a range of 1.5 to 3.0 percent a yeir from 1985 to 2000 , with rates of increase for coal prices projected to fall in a range of 0 to 1.5 percent. 
An on-site coal gasification plant supplying hydrogen in the quantities usually required in chemical applications (from 10 to 100 million cubic feet per day) will be smaller than is generally proposed for syngas plants. Nevertheless, substantial investment costs for gasification plants will be an important barrier to industrial production of hydrogen by this means. Financing a gasification plant as a utility-owned facility would significantly reduce the costs of hydrogen production. However, the rationale and incentives for utility ownership of hydrogen production facilities need to be examined.

- Growth in smaller scale specialty uses of hydrogen and improvements in the technology for electrolysis will create conditions favorable to expanded use of hydrogen produced through water electrolysis. The major constraint on use of electrolysis will be the availability of low cost electricity. In the near term, electrolysis technology will allow the use of the low cost electric power (10 to 20 mills per kilowatt-hour) available at low head hydro sites. Projections of installed nuclear generating capacity indicate that significant amounts of power at off-peak cost will not be available for most utilities until the late 1990 's. However, with increasing prices for natural gas, full cost electricity supplied from nuclear plants could be used to produce competitively priced hydrogen for small scale uses.

Shortages of natural gas caused by declining domestic production could induce shifts to producing hydrogen through electrolysis or through coal gasification earlier in time (i.e., the late $1980^{\prime}$ 's or early $1990^{\prime} \mathrm{s}$ ) than is suggested by comparative cost calculations alone.

While there are no alternatives to hydrogen in its existing chemical applications, alternatives are available in fuel applications, and sensitivity to the cost of hydrogen therefore can be expected to be greater. The rate at which the costs of producing hydrogen are lowered will be a primary factor in determining how rapidly new, fuel applications for hydrogen develop. 
The following paragraphs summarize the analysis on which the preceding conclusions are based.

Hydrogen is currently used in a number of chemical applications, primarily in manufacturing ammonia and methanol and in refining petroleum but also in a variety of smaller scale specialty uses (e.g., fats and oils hydrogenation, reduction of nonferrous metals, and metal-treating atmospheres). Figure 1 shows the growth projected for each of these market segments. The requirements shown for hydrogen in petroleum refining represent only that hydrogen which will be supplied through separate hydrogen generation, either for desulfurization of residual oil and gas oils or for hydrocracking of residual oil. Rapid growth in hydrogen requirements for these purposes reflects the shift expected in the types of crude oil to be refined, particularly to crudes with high sulfur content. (Although hydrogen is also required to desulfurize light distillate streams, this hydrogen is supplied as a by-product of other refining processes.) The ammonia market is nearing maturity after rapid growth in the $1960^{\prime} \mathrm{s}$ and early $1970^{\prime}$ 's and consequently will grow at a lower rate. Methanol is considered only in its chemical applications, although significant use of methanol as a fuel would increase the requirements for hydrogen. Specialty uses of hydrogen have grown rapidly in recent years, and continuation of this trend may be expected.

Most of the hydrogen currently used in these chemical applications is produced through steam reforming of natural gas. However, the existence of these applications provides a base market. for penetration by new hydrogen production technologies, either advanced coal gasification technology or advanced water electrolysis technology. Thermochemical water splitting to produce hydrogen is also being studied, but the technical feasibility of this approach must be more firmly established before cost calculations can be considered reliable.

Hydrogen generally is produced and consumed at the site of use in quantities ranging from $10 \mathrm{million}$ to 100 million cubic feet-per day. Figure 2 compares the costs of producing these quantities of hydrogen using natural gas and using current coal gasification technology. Much of the difference in costs is attributable to the gasification plant requiring an initial investment about twice that for a hydrogen generator using natural gas; about 80 percent of the cost of producing hydrogen through coal gasification is accounted for by capital costs. Two major factors may contribute to narrowing the difference in costs: 
- New coal gasification technologies now under development will offer lower capital costs and higher efficiencies in producing hydrogen. In particular, the use of high pressure gasification will permit reductions of 15 to 20 percent in the investment costs of a plant using the new technology. This will reduce the cost of producing hydrogen by about 12 to 16 percent. For example, hydrogen costing about $\$ 8.15$ per million Btu (1980 \$) may be produced in a plant having a capacity of 100 million cubic feet per day, equipped with new technology and using coal priced at $\$ 20$ a ton.

- As the price of natural gas rises relative to the price of coal, the cost comparison will shift in favor of hydrogen produced through coal gasification. The price of natural gas between now and 1985 will probably be controlled by the natural gas pricing bill now before Congress. Under the provisions of this bill, natural gas would be priced at about $\$ 2.35$ per million Btu (1980 $\$$ ) in 1980 and about $\$ 2.85$ per million Btu (1980 $\$)$ in 1985. Based on a review of several recent studies projecting prices for natural gas and for coal, the price of natural gas will rise at a rate between 1.5 and 3.0 percent a year from 1985 to 2000 , while the price of coal will. rise at between 0 to 1.5 percent. Figure 3 shows the timing for the cost of producing hydrogen from natural gas to rise to the costs of producing with new coal gasification technology. Under favorable conditions (i.e., use of new gasification technology, no rise in coal prices, rapid rise in natural gas prices), hydrogen produced through coal gasification becomes cost competitive about the year 2000 .

The cost comparisons presented in Figures 2 and 3 assume that the gasification plant is owned by a private industrial firm and financed completely through the use of equity. Because of the high capital intensity of the gasification plant, however, a method of financing which lowered the capital charges against the plant would also lower the costs of producing hydrogen. In particular, if the gasification plant could be financed as a utility-owned facility, Figure 4 shows that the cost of producing the hydrogen would be significantly lower. However, the economic and institutional implications of utility ownership of hydrogen production facilities need to be assessed. 
While coal gasification appears to be the most likely alternative to using natural gas to produce relatively large quantities of hydrogen, water electrolysis would appear to be more competitive for supplying small scale uses (i.e., less than 1 million cubic feet a day). Figure 5 compares the costs of producing hydrogen using advanced electrolysis technology (based on the Solid Polymer Electrolyte) and using small natural gas reformers. The cost of producing hydrogen through electrolysis is dominated by the cost of electricity, but relatively low-cost electricity may be available from two major sources:

- Although most major sites for hydroelectric power (the source of lowest cost electricity) are already in use, a recent survey suggests that about 60,000 low head hydro sites are available in the U.S. About one-third of these sites are located in the Northeast. Depending on the head and other topographical features, electric power might be supplied from these sites at 10-20 mills per kilowatt-hour and in quantities allowing production of 100 thousand to 1.5 million cubic feet of hydrogen a day at each site.

- Electricity from nuclear power plants is a second major source of low cost electricity. Projections of installed nuclear generating capacity indicate that significant amounts of power at off-peak costs will not be available for most utilities until the late 1990's. However, Figure 5 indicates that full cost electricity from nuclear plants could be used to produce competitively priced hydrogen for small scale uses. A substantial increase in the price of natural gas relative to the cost of electricity would be required to broaden the range in which electrolysis is cost competitive with natural gas reforming.

Comparative cost calculations do not take into account the probability that restrictions on the availability of natural gas because of declining domestic production may induce a shift to producing hydrogen either through electrolysis or through coal gasification. On present projections of domestic natural gas production, these shifts may become prevalent by the early 1990's. Figure 6 shows that under such circumstances electrolysis and coal gasification will be complementary, not competitive, technologies for producing hydrogen. That is, the high ratio of capital costs to energy costs for coal gasification plants better suits them to production of large quantities of hydrogen, while the low ratio of capital costs to energy costs for electrolyzers suits them to the production of hydrogen for 
small scale uses. Moreover, Figure 7 , showing the locations of coal and nuclear resources for production of hydrogen, suggests that electrolysis and coal gasification are also complementary in geographical terms. In particular, electrolysis might prove attractive in the Northeast and in the West where the availability of nuclear (and hydro) power can compensate for the lack of coal resources.

Prospects for the use of hydrogen in fuel applications remain unclear. On one hand, there is some agreement on the general pattern by which the transition to the use of hydrogen for fuel applications will occur, if it does indeed occur. In the intermediate term, hydrogen could come into use for utility applications (for load leveling by electric utilities and for natural gas supplementation) and perhaps in air transportation. While hydrogen used in utility applications would probably be produced and consumed at the same site, use of hydrogen for air transportation would represent the first step to broader use of merchant hydrogen. In the far term then, hydrogen might be used for ground transportation vehicles and for residential/commercial uses.

There is, however, no agreed understanding on the timing and the extent of the transition to using hydrogen in fuel applications. Hydrogen as a fuel will be competing with other fuels, and the rate at which the costs of producing hydrogen are lowered relative to the costs of other fuels will be a primary determinant of how rapidly the use of hydrogen as a fuel increases. However, if new technologies for producing hydrogen do not come into extensive use for chemical applications until the 1990's, hydrogen as a fuel will probably not be realized in significant quantities until several decades into the 21 st century. Accelerating the penetration of new hydrogen production technologies into existing markets based on chemical applications could provide the learning experience which would enhance the probabilities for use of these technologies in fuel applications. 


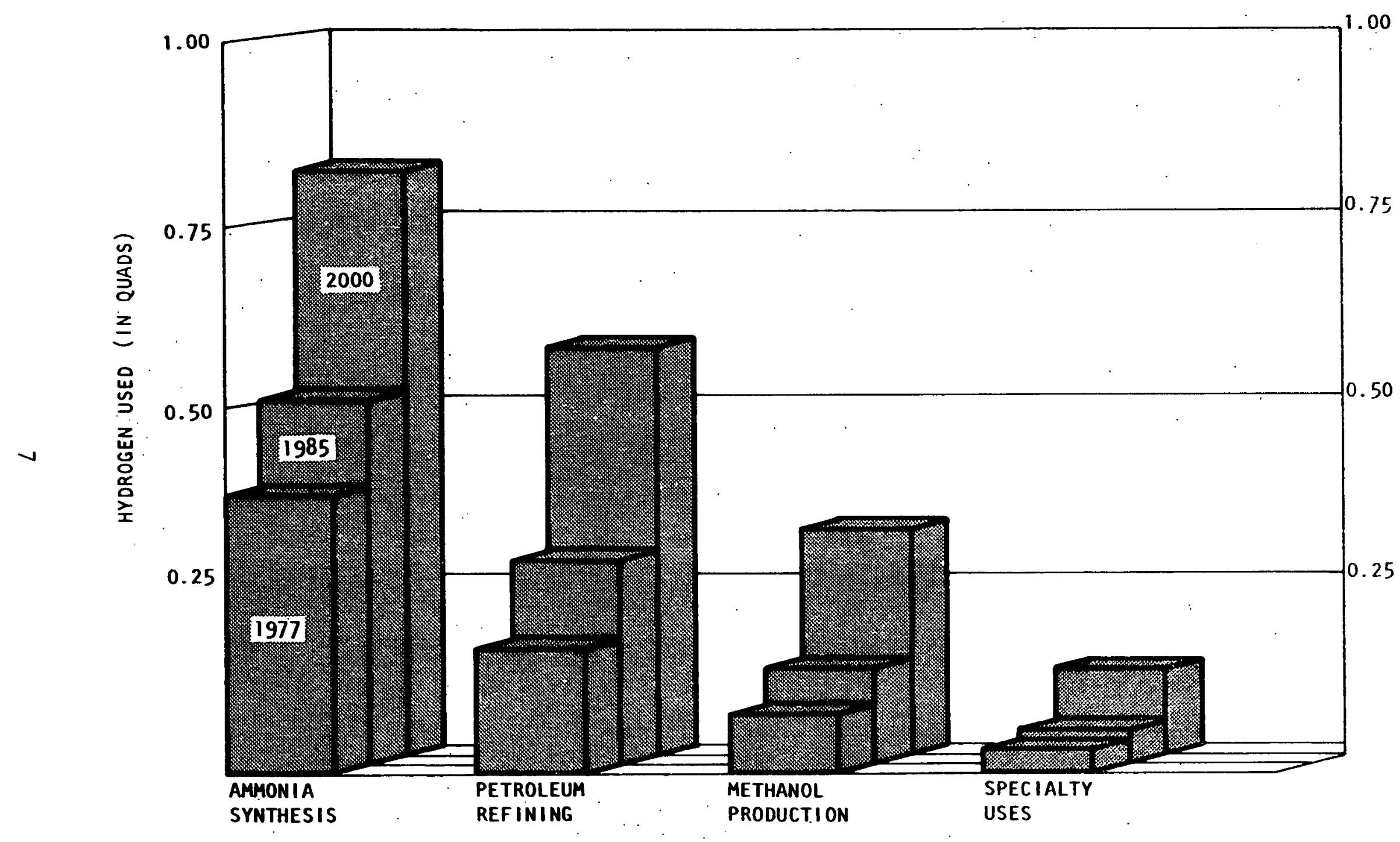

Figure 1. Hydrogen Use in Chemical Applications 


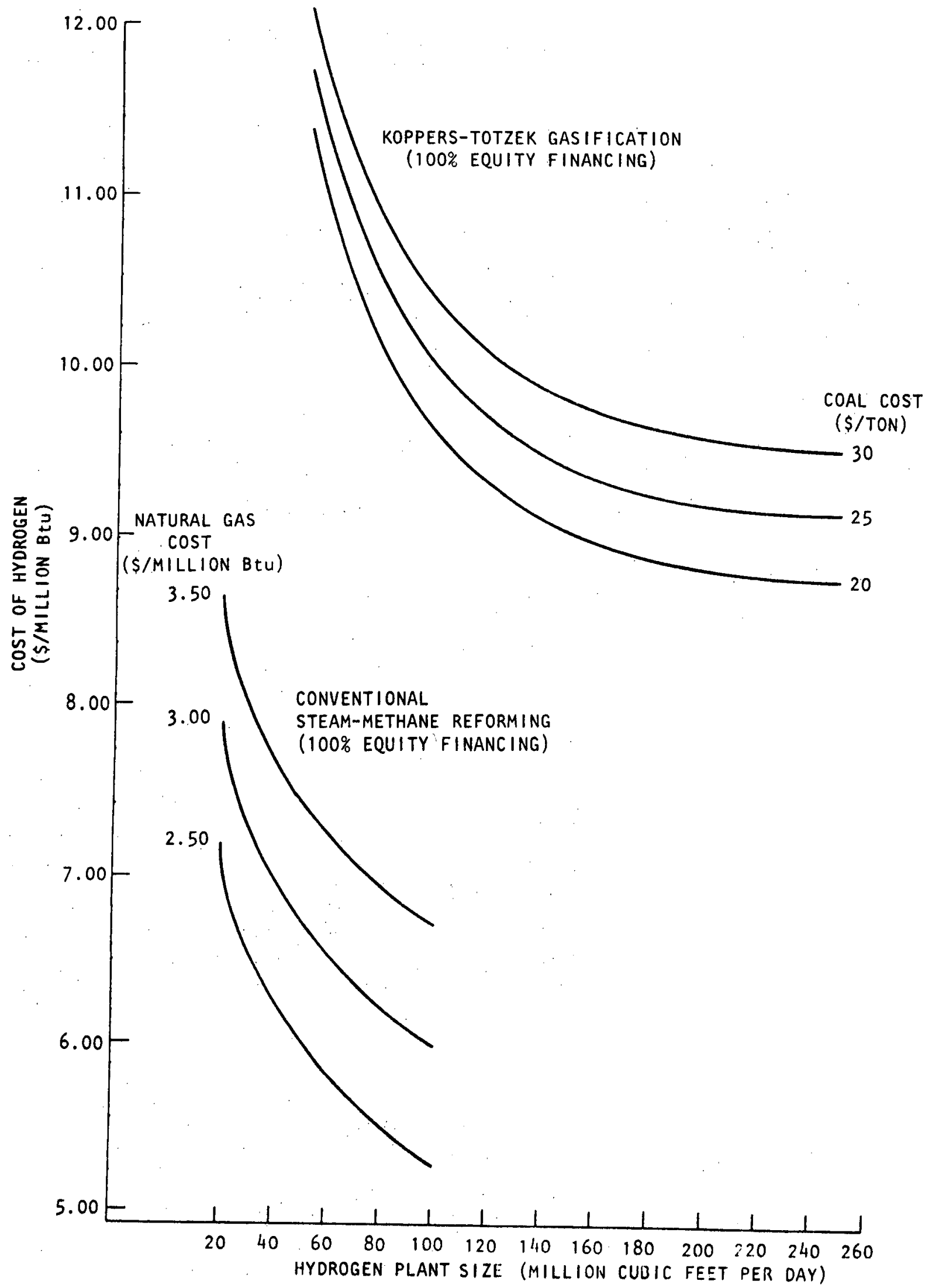

Figure 2. Comparative Costs of Producing Hydrogen Steam-Methane Reforming vs. Coal Gasification, 1980 \$ 


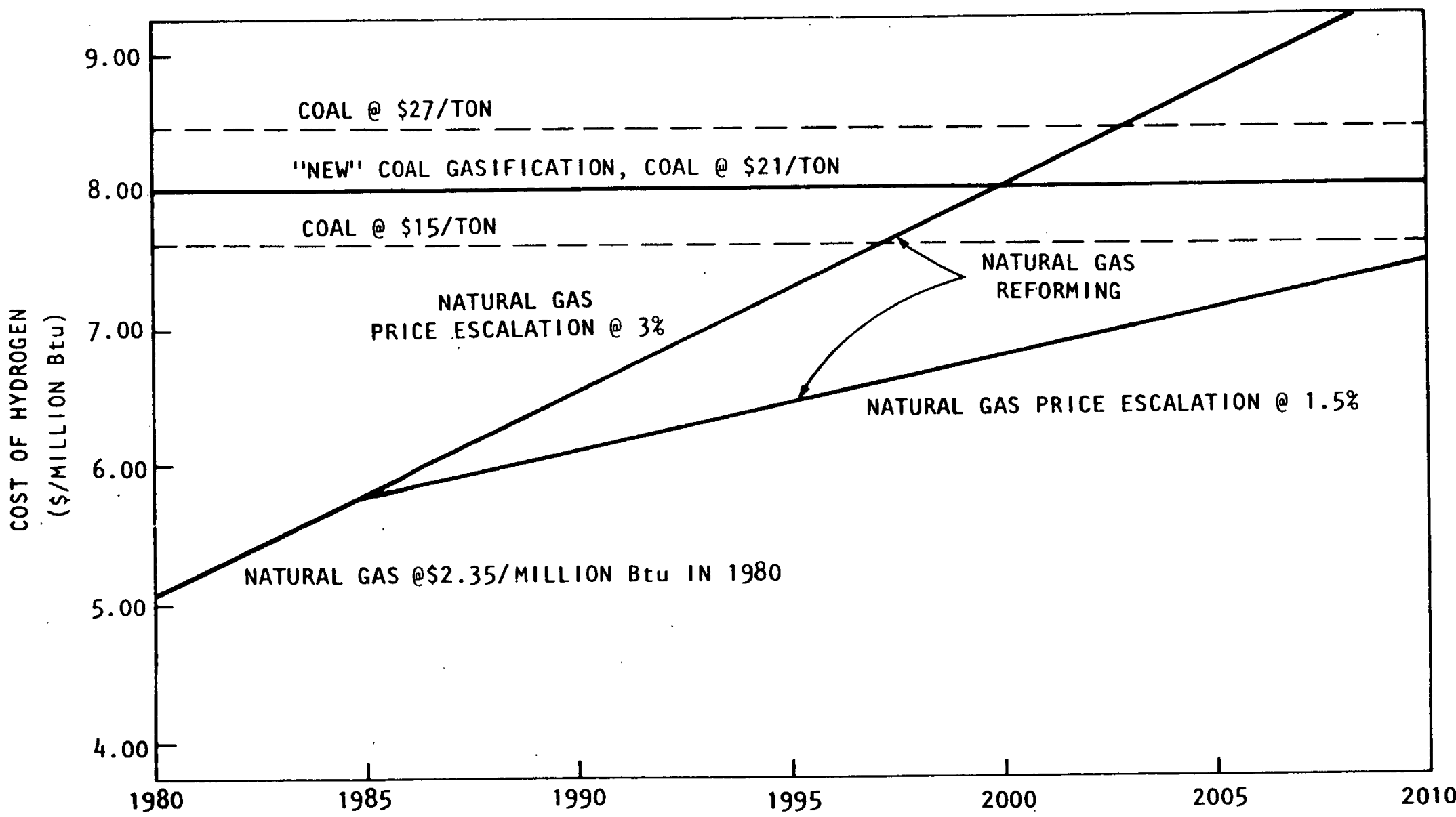

Figure 3. Hydrogen Production Costs Natural Gas Reforming vs. "New" Gasification

100 fiillion SCF/Day Plant, 1980 \$ 


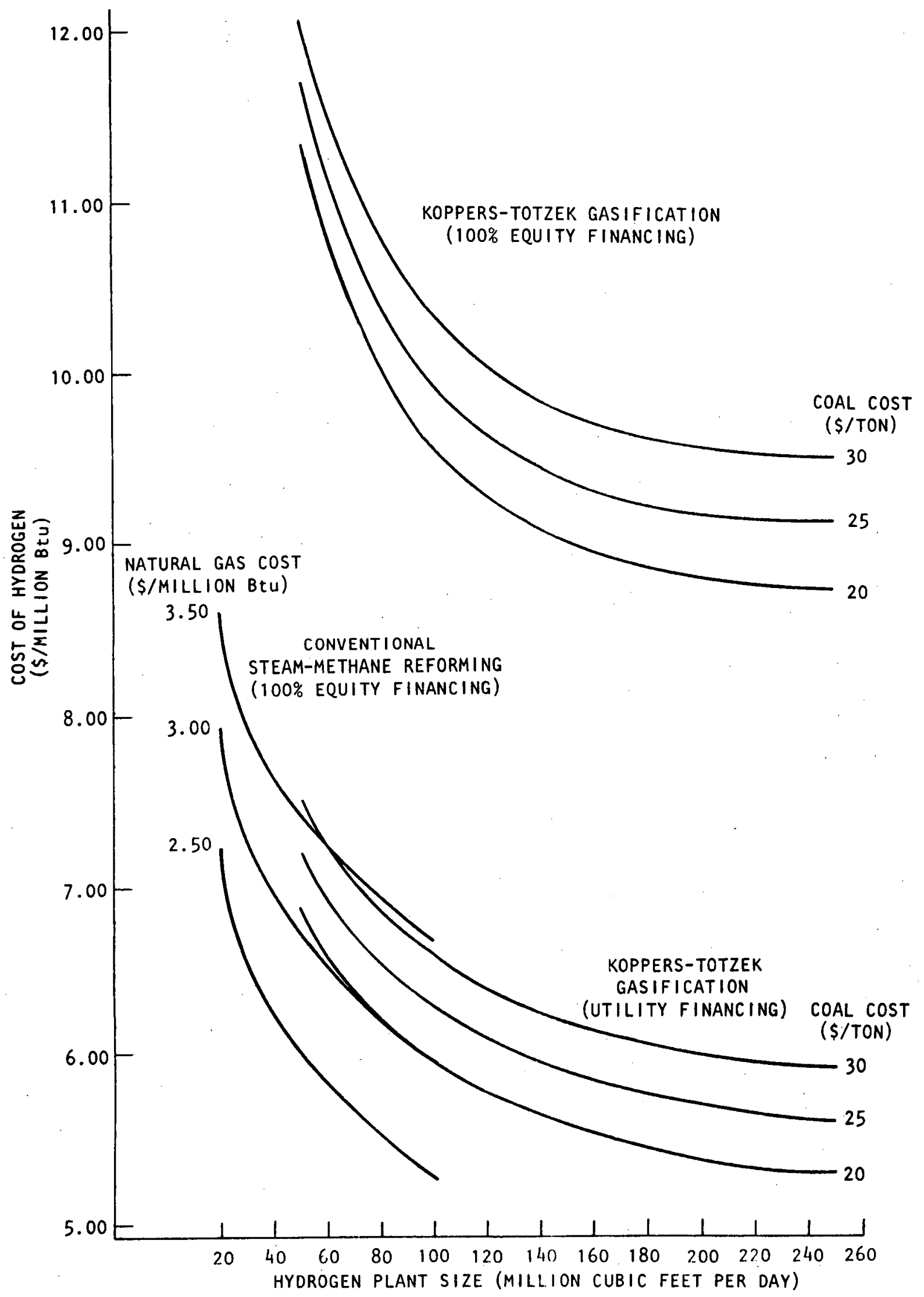

Figure 4. Comparative Costs of Hydrogen through Coal Gasification Equity vs. Utility Financing, $1980 \$$ 


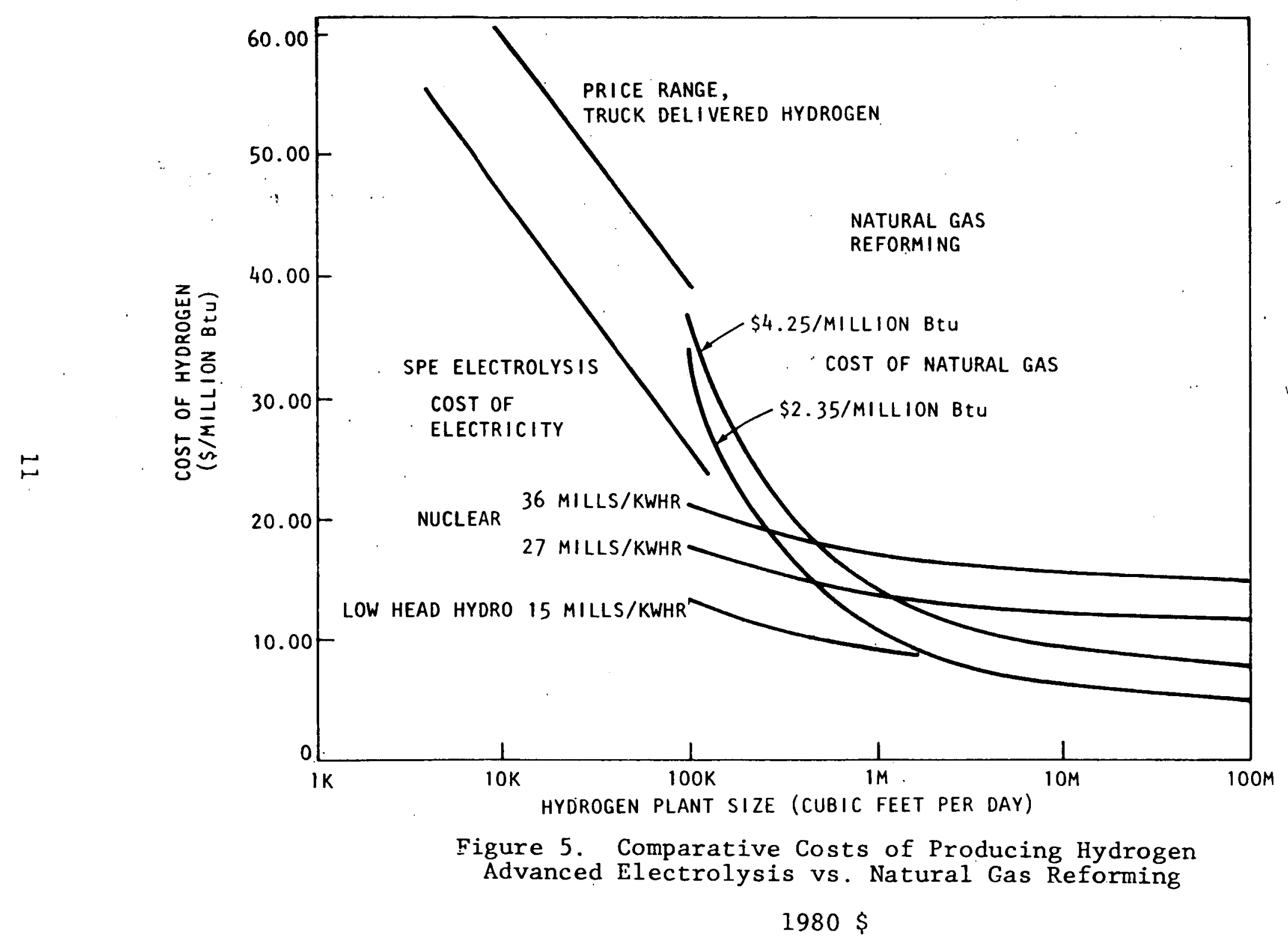




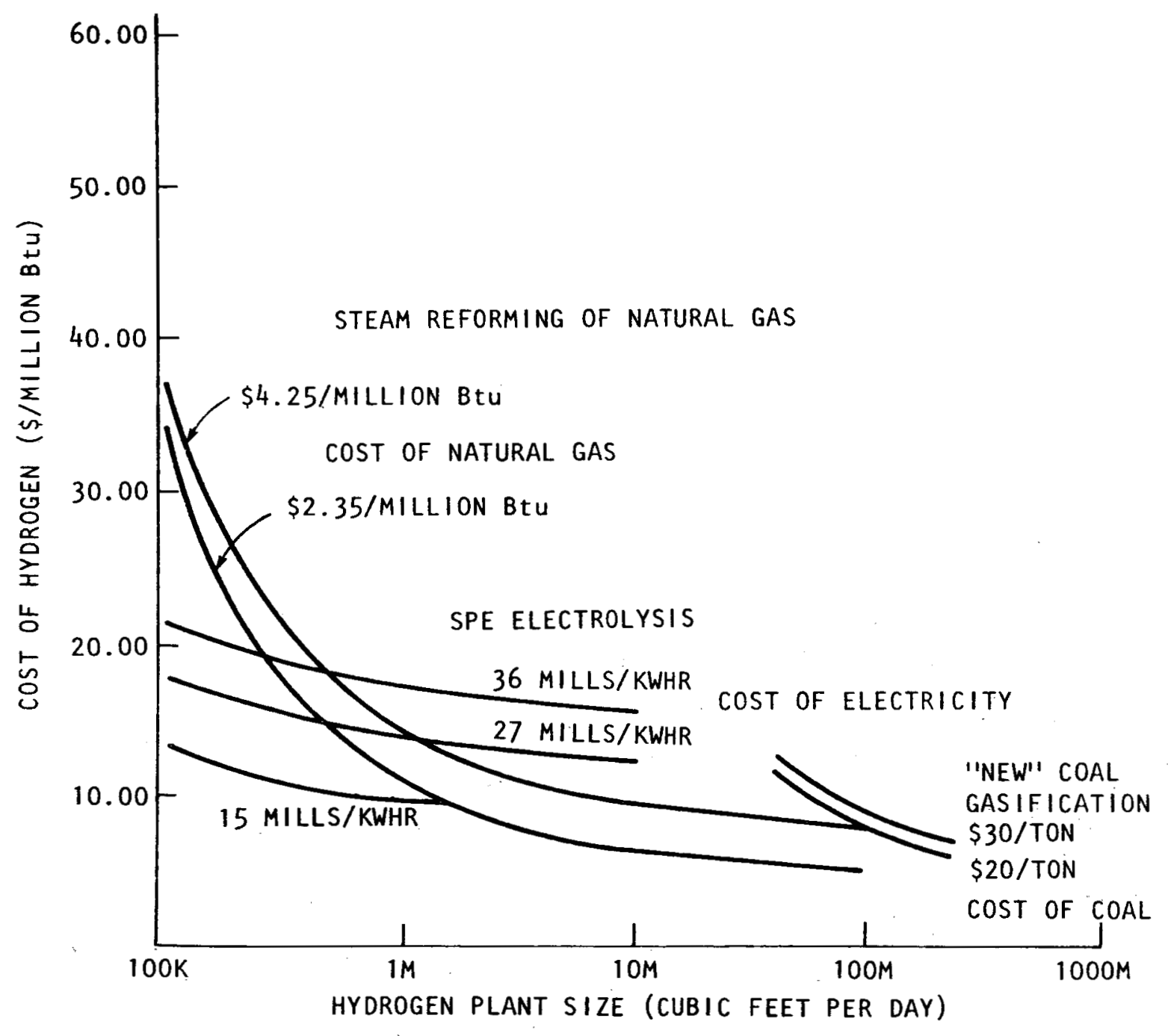

Figure 6. Comparative Costs of Producing Hydrogen by Natural Gas Reforming, Advanced Electrolysis, "New" Coa1 Gasification $1980 \$$ 


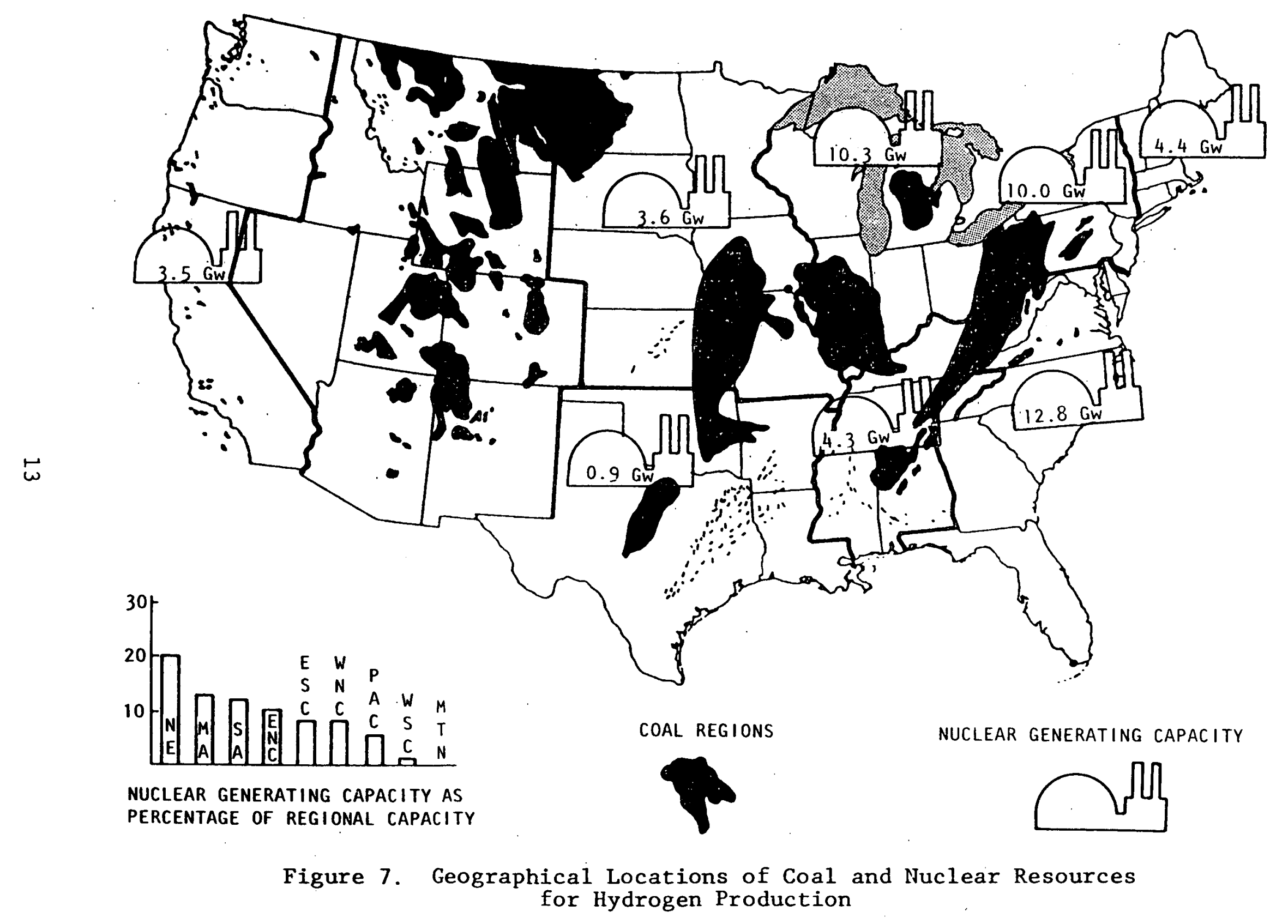




\section{INTRODUCTION}

\section{A. Scope of Study}

During this study, previous work on hydrogen production from water and from coal was reviewed and analyzed in order to evaluate the economics of hydrogen production and to assess the market potential for hydrogen. Existing and proposed technologies for producing hydrogen were considered in evaluating the economics of hydrogen production. Assessment of market potential considered the demand for hydrogen in chemical applications (both captive and merchant) and in fuel applications (stationary and mobile). These evaluations considered not only the years before 2000 , but also the period beyond 2000 .

\section{B. Sources of Data}

Since the basis for this study was a review and analysis of previous studies on technologies and markets for hydrogen production, it was important that all relevant documents be identified and collected. Accordingly, various means were used to gather the appropriate information.

- The principal hydrogen reports identified in an annotated bibliography prepared by contractors for the Energy Storage Division of DOE were gathered. These reports provided the basic source material for this study.

- Other literature sources were searched to identify studies on hydrogen production performed by individuals or organizations not working under the auspices of DOE. This search made use of bibliographics on hydrogen published by the University of New Mexico and by the National Bureau of Standards.

- The RECON information retrieval system of DOE was used to establish an annotated listing of hydrogen studies.

- The expert review panel assembled by HAI for this study was consulted for information on relevant work, particularly ongoing studies whose results were not yet published. 
- Studies not specifically related to production and use of hydrogen were also used, particularly to examine prospective costs and availabilities of natural gas, coal, electricity and other primary and secondary sources of energy.

\section{Methodology}

Hydrogen currently is used in the manufacture of ammonia and methanol, in petroleum refining, and in a variety of smaller uses (e.g., synthesis of chemicals besides ammonia and methanol, metallurgy, semi-conductor manufacture, hydrogenation of fats and oils, etc.). Accordingly, projections of growth for these uses were first surveyed and evaluated in order to assess the size of the market these uses might provide for the penetration of new hydrogen production technologies. In addition, various characteristics of the uses of hydrogen (e.g., sensitivity to the cost of hydrogen, purity required, scale of use, etc.) were examined in order to identify the conditions which new production technologies will have to meet if they are to penetrate these markets.

For each use of hydrogen examined, estimates were gathered from the various studies on the quantity of hydrogen demanded for that end use (for selected years), and the assumptions about industry growth rates and other economic variables on which the demand estimates were based were identified and evaluated. This evaluation indicated the variation among studies in the estimates of hydrogen use and in the assumptions made. Those end uses of hydrogen where estimates of hydrogen use varied significantly among studies were examined further to identify the reasons for the variation. Based on this examination and reconciliation of estimates among studies, a "best" estimate of demand for each hydrogen end use in selected years was arrived at.

Following the evaluation of the demand for hydrogen in existing uses, estimates which were made of the costs of producing hydrogen with different technologies were surveyed and evaluated. Brief descriptions of the technologies for producing hydrogen through natural gas reforming, coal gasification, electrolysis and thermochemical water splitting were developed. Drawing on these descriptions, the costs of producing hydrogen with each technology were evaluated. The economics of production with these technologies depend fundamentally on the cost and availability of feedstocks and utility power and on the capital costs of the production facility, and particular emphasis was placed on consideration of these factors. The separate evaluations of each technology were then used to compare the alternative methods of producing hydrogen. 
In evaluating the economics of hydrogen production technologies, the ranges of values were identified for a number of process-specific variables, including capital costs and efficiencies. In addition, ranges of values were identified for variables not specific to processes, particularly for prices of fuels (natural gas, coal, oil) and utility power. The association between estimates of hydrogen production costs and the underlying explanatory factors (e.g., process efficiencies, fuel prices, etc.) was determined through graphical and statistical analyses. These analyses also permitted the identification of those variables affecting hydrogen production costs for which estimates among studies varied significantly.

Finally; possible new uses of hydrogen were surveyed in order to identify the conditions under which hydrogen could be brought into use. Based on these considerations, the potential markets for hydrogen in prospective uses were evaluated as to their probable growth and the timing for the transition to the use of hydrogen. Many of the proposed new uses for hydrogen represent fuel applications. Unlike existing chemical applications of hydrogen, where no alternatives to the use of hydrogen exist, most of the prospective fuel applications could be met using alternative means. The market potential for hydrogen in these applications therefore related directly to the evaluation of the economic competitiveness of hydrogen with alternative fuels.

In accomplishing these various tasks, use was made not only of HAI's in-house expertise in economic and market analyses and in the technology of hydrogen production but also of advice from outside experts. A panel of experts including Dr. E.M. Dickson of SRI International, Mr. A.P. Fickett of Electric Power Research Institute, and $\mathrm{Clem}$ Systems, Inc. was assembled to provide support to the Hittman team. In addition, the results of the study were reviewed at various stages by the Hydrogen Coordinating Committee of the Department of Energy. 
Hydrogen is currently used primarily in the manufacture of ammonia and methanol, in petroleum refining, and in a variety of smaller uses, such as the synthesis of chemicals other than ammonia and methanol, metallurgy, semiconductor manufacture, and hydrogenation of fats and oils. This chapter surveys and evaluates projections of growth for these uses in order to assess the size of the market these uses might provide for hydrogen in the future. In addition, various characteristics of the uses of hydrogen; such as sensitivity to the cost of hydrogen, purity required, and scale of use; are examined in order to identify the conditions that new production technologies will have to meet if they are to penetrate these markets.

\section{A. Hydrogen in Ammonia Synthesis}

1. Projected Growth of Hydrogen Use

With 70,000 to 80,000 cubic feet of hydrogen required to produce one ton of ammonia, production of ammonia gives rise to a significant demand for hydrogen. In the aggregate, hydrogen used in the production of ammonia has accounted for between 40 and 50 percent of the hydrogen used in the $\mathrm{U} . \mathrm{S}$. in recent years.

Projections from various studies of the expected growth in the use of hydrogen in ammonia synthesis are summarized in Table II-1. Hydrogen use in future years was projected in most of the studies by selecting an estimate of hydrogen use in a base year and then projecting that use at some assumed rate of growth. Growth rate assumptions were arrived at by various lines of reasoning.

(a) The Jet Propulsion Laboratory (JPL) projections are based on an evaluation of the trend in ammonia use over the period from 1964 through 1973. The average annual rate of growth for that period was calculated to be 9.3 percent. For their reference case, however, JPL lowered the projected growth rate to 6 percent to account for (1) a lower growth rate in foreign markets for U.S. fertilizer, and (2) increasing self-sufficiency in ammonia production in foreign countries. JPL's expanded production scenario projected continued growth at 9.3 percent a year. 
TABLE II-1. PROJECTIONS OF HYDROGEN USE IN AMMONIA SYNTHESIS

(In Quads)

\begin{tabular}{|c|c|c|c|c|c|c|c|}
\hline Refer & Study & $\begin{array}{l}\text { Base } \\
\text { (Year) }\end{array}$ & $\begin{array}{l}\text { Estimate } \\
\text { Quantity }\end{array}$ & 1985 & 2000 & \multicolumn{2}{|c|}{$\begin{array}{l}\text { Assumed Growth } \\
\text { Rate }\end{array}$} \\
\hline \multirow[t]{2}{*}{ (1) } & $\begin{array}{l}\text { Jet Propulsion Laboratory } \\
\text { Hydrogen Tomorrow }\end{array}$ & & & & & & . \\
\hline & $\begin{array}{l}\text { Reference Scenario } \\
\text { Expanded Scenario }\end{array}$ & $\begin{array}{l}(1973) \\
(1973)\end{array}$ & $\begin{array}{l}0.36 \\
0.36\end{array}$ & $\begin{array}{l}0.73 \\
1.04\end{array}$ & $\begin{array}{l}1.73 \\
3.96\end{array}$ & & $\begin{array}{l}6.0 \% \\
9.3 \%\end{array}$ \\
\hline (2) & $\begin{array}{l}\text { Brookhaven National Laboratory } \\
\text { Hydrogen Energy Assessment }\end{array}$ & (1973) & 0.34 & 0.54 & 0.92 & & $3.6 \%$ \\
\hline (3) & $\begin{array}{l}\text { Exxon Research and Engineering } \\
\text { Production Economics... }\end{array}$ & (1975) & 0.35 & 0.55 & 0.90 & $\begin{array}{l}4.5 \% \\
3.4 \%\end{array}$ & $\begin{array}{l}1970-80 \\
1980-2000\end{array}$ \\
\hline \multirow[t]{2}{*}{ (4) } & $\begin{array}{l}\text { U.S. Bureau of Mines } \\
\text { Mineral Facts and Problems }\end{array}$ & & & & $\therefore$ & & \\
\hline & $\begin{array}{l}\text { Low } \\
\text { Probable } \\
\text { High }\end{array}$ & (1973) & 0.33 & & $\begin{array}{l}0.64 \\
0.75 \\
0.81\end{array}$ & & $\begin{array}{l}2.5 \% \\
3.1 \% \\
3.4 \%\end{array}$ \\
\hline (5) & $\begin{array}{l}\text { Institute of Gas Technology } \\
\text { Survey of Hydrogen Production }\end{array}$ & (1973) & 0.34 & 0.60 & 1.10 & & $4.5 \%$ \\
\hline (6) & $\begin{array}{l}\text { Institute of Gas Technology } \\
\text { Utilization of Off-Peak Power }\end{array}$ & (1974) & 0.37 & 0.53 & (1990) & 0.62 & $4.0 \%$ \\
\hline
\end{tabular}


(b) In their Hydrogen Energy Assessment, Brookhaven National Laboratory (BNL) assumed that production of ammonia will follow the growth of the petrochemical industry. A growth rate of 3.6 percent a year projected for that industry by ERDA was used to project hydrogen use.

(c) The projections in the study by Exxon Research and Engineering Company were taken directly from a study on Chemicals from Coal and Shale by Chem Systems, Inc. [Ref. 7]. In that study, Chem Systems projected a lowering of the growth rate for ammonia production from 4.5 percent a year for the period 1970-1980, to 3.4 percent for the period 1980-2000. This lowering of the growth rate was premised on the demand for fertilizer growing more slowly between 1980 and 2000 .

(d) No explanation was provided for the growth rate of 3.1 percent projected by the Bureau of Mines in Mineral Facts and Problems. The higher and lower growth rates represent contingency projections, based on forecasted use of nitrogen and chemicals.

(e) In their Survey of Hydrogen Production the Institute for Gas Technology (IGT) estimated a historical growth rate of 4.5 percent for hydrogen use in ammonia production and projected continued growth in use at that rate. Their later study on Utilization of off-Peak Power drops the expected growth rate to 4 percent.

As several of the studies make clear, the major use of ammonia is in the production of fertilizer. Hence, trends in the use of ammonia, and thereby in the requirements for hydrogen to produce ammonia, are tied closely to trends in fertilizer production. Several of the studies arrive at their assumed growth rates through evaluation of historical trends in the use of ammonia during the 1960's and early 1970 's. However, there are several reasons to believe that the growth in the use of ammonia which occurred over that period will not continue at the same rate in the future.

Consider first several trends which contributed to fairly rapid growth in the use of ammonia during the 1960's and 1970's: First, technological innovations made in the. early 1960's made possible the construction of ammonia plants significantly larger in scale than those previously constructed. The economies of production in the new larger scale plants lowered the cost of ammonia to customers [Ref. 81. Second, increased demand for agricultural products, particularly for grain crops, encouraged farmers in the U.S. to increase the amount of acreage they planted to crops. 
Between 1969 and 1974, for example, the amount of cropland left idle fell from 51 million acres to 20 million acres [Ref. 9]. Along with increasing the acreage planted to crops, farmers were also increasing the amount of fertilizer they used on each acre. Third, foreign countries which did not yet have their own fertilizer production capacity provided an export market for U.S. fertilizer producers.

Since 1976, however, ammonia production has increased at rates noticeably lower than in the past, and current forecasts are for a production level in 1978 that will be at most one percent higher than in 1977 [Ref. 10]. Although the long-run rate of growth of ammonia production cannot be expected to remain as low as one percent a year, it is also unlikely that the rate of growth will again reach the levels experienced during the 1960's and early 1970's. Reversals in several of the trends which contributed to the rapid growth in ammonia production are the basis for this conclusion. First, the economies realized in the production of ammonia in large scale plants now appear to be near exhaustion, and the scale of newly built ammonia plants is unlikely to increase substantially in the future [Ref. 11]. Second, the amount of acreage left to be planted to crops is relatively small and is not sufficient to sustain increased production of the magnitude realized in the early 1970's. Moreover, major crops, such as corn, appear now to be fertilized to the maximum economic rate. Third, foreign markets for U.S. fertilizers are shrinking as foreign countries either produce their own fertilizer or shift their purchases of fertilizers to countries now able to produce fertilizer with natural gas priced lower than that available in the U.S. Moreover, imports of fertilizer into the U.S. may become increasingly significant. Reserves of natural gas in Canada, the Caribbean, and Mexico appear sufficiently large to support significant production of fertilizer in those countries, with part of this production being exported to the U.S. [Ref. 12].

On the basis of these considerations, it would seem likely that the rate of growth of the use of ammonia and hence the related requirement for hydrogen will fall at the lower end of the range of assumed growth rates presented in Table II-1. This would suggest future rates of growth in the range of 3.1 to 3.4 percent a year.

One hypothesis in the economics of technological change is that the receptivity to investment in innovations is highest when the demand for the product to be produced with the innovation is growing rapidly. For example, rapid growth in the demand for ammonia during the 1960's encouraged the innovations leading to larger scale ammonia plants. 
Conversely, however, if the demand for ammonia does indeed grow significantly more slowly in coming years, then the demand for additional production capacity in general and for new hydrogen production technology in particular will also be dampened. Currently, for example, ammonia production capacity in the U.S. is operating at less than an 80 percent utilization rate, reflecting the significant amount of new capacity which came on line in the past two years (in response to the high level of demand for ammonia in 1973 and 1974) at the same time that the growth in demand for ammonia has been ebbing [Ref. 10]. Such levels of underutilized capacity, of course, discourage investment in new capacity. If demand for ammonia grows only around 3 percent a year, existing unused capacity will be brought back into production no earlier than the mid-1980's.

This line of argument carries some implications for the market available to new hydrogen production technologies. First, the size of the market is constricted, making penetration by the new, untried technologies more difficult. Second, slow penetration by the new technologies will reduce the learning experience on these technologies and thereby impede further their acceptance. These points would seem to bear directly on the program DOE is currently funding with W.R. Grace and Co., to examine the feasibility of using a coal gasification plant to produce hydrogen for ammonia synthesis. If the rates of growth in ammonia demand suggested above hold, there will still be significant excess capacity for ammonia production in the early $1980^{\prime} \mathrm{s}$ when the DOE/Grace program reaches the decision point on construction of an operating facility.

2. Conditions on Use of New Hydrogen Production Technologies in Ammonia Synthesis

Because there is no substitute for hydrogen in the production of ammonia, the demand for hydrogen shows little sensitivity to changes in the cost of hydrogen relative to the costs of capital, labor and other production inputs. However, hydrogen from one source (e.g., coal) can substitute for hydrogen from another source (e.g., natural gas); and the demand for hydrogen from a particular source therefore shows more sensitivity to the cost at which it is produced. Because of the historically low rates for natural gas, all ammonia plants in the U.S. produce the hydrogen required through catalytic reforming of natural gas. With prices for natural gas as low as 20 cents per 1,000 cubic feet, gas costs accounted for only about 40 percent of the variable costs of producing ammonia. With gas prices at $\$ 2.00$ per 1,000 cubic feet, however, gas costs can account for 75 percent or more of variable production costs [Ref. 14]. 
This growing importance of gas costs has increased the sensitivity of ammonia producers to the cost of producing hydrogen and has encouraged interest in hydrogen from other sources, such as coal gasification.

The long-standing reliance on producing hydrogen from natural gas, however, has shaped the development of the technology used to produce ammonia. Dickson, et al., point out that:

...because the rate of methane in providing nitrogen is not widely known, it was easy to assume that the abandonment of methane as a feedstock would only affect the plant's source of hydrogen. But, in fact, because the designs [for hydrogen production and for ammonia synthesis] have been so highly integrated, abandonment of methane would necessitate the redesign of nearly the entire plant [Ref. 15].

A recent paper by engineers in TVA's Division of Chemical Development describes the necessary changes:

If partial oxidation of coal becomes the substitute for the more conventional NH3 processes, drastic changes in the design of the "front end" (synthesis gas production) of existing ammonia plants will be required. The two-stage gas reformer would be replaced with coal gasifiers with the necessary coal handing and preparation and ash disposal systems, the gas scrubbers would double in number and size for removal of $\mathrm{H} 2 \mathrm{~S}$ as well as $\mathrm{CO} 2$, and an air separation plant would be added to supply oxygen and nitrogen [Ref. 16].

Dickson et al., also point out that "experts in ammonia production report that if methane were not available as a feedstock to an ammonia synthesis plant, it would prove more effective to turn to nearly any alternative liquid or gaseous hydrocarbon in preference to hydrogen, because this would result in the smallest overall change in existing plant designs and operations [Ref. 15]." This implies that the use of merchant hydrogen in the production of ammonia could take place only after significant barriers had been overcome. Thus, even if new technologies for producing hydrogen become available, the production of hydrogen from any new technology will have to be integrated with the ammonia synthesis process.

Various studies are now underway to assess the possibilities of integrating hydrogen production through coal gasification with the ammonia synthesis process. The economics of hydrogen production through coal gasification are addressed in Chapter III. On the assumption that the hydro- 
gen production process is integrated with the ammonia synthesis process, it follows that the scale of the coal gasification plant used to produce hydrogen must be commensurate with the scale of the ammonia synthesis plant. The optimal scale for an ammonia plant falls in the range of 1,000 to 1,500 tons of production per day [Ref. 17]. If 80,000 cubic feet of hydrogen are required for each ton of ammonia produced, and if the ammonia plant produces 1,500 tons of ammonia per day, then hydrogen production of 120 million cubic feet per day would be required. This magnitude of production can be interpreted as the upper limit on the acale of the hydrogen production facility.

\section{B. Hydrogen in Methanol Production}

1. Projected Growth in Hydrogen Use

The second largest use of hydrogen in the chemical industry is in methanol production. Methanol itself is used primarily in the production of formaldehyde and solvents.

Table II-2 provides a summary of estimates from var1ous studies of the current and projected use of hydrogen in methanol production. Base estimates differ primarily because of different estimates of methanol production in the base year and different estimates of the quantity of hydrogen required to produce a pound of methanol.

(a) JPL's base estimate was calculated using methanol production capacity in 1973 (approximately 1,200 mililon gallons) and assuming 37.5 SCF of hydrogen are required to produce one pound of methanol.

(b) Broolhaven's base estimate is consistent with the data for 1973 reported in Mineral Facts and Problems for hydrogen consumption in production of methanol plus production of other minor chemicals. Hydrogen required for production of these other chemicals in 1973 would account for 0.038 quads of Brookhaven's base estimste.

(c) The Exxon estimate for hydrogen use in 1975 is calculated assuming methanol production of 1,150 million gallons and assuming the hydrogen requirement is measured by the stoichiometric hydrogen contained in the methanol molecule. This latter assumption, however, Implies a hydrogen requirement per pound of methanol produced of about 23 SCF, which falls below the range of 26 to 37 SCF usually regarded as setting the requirement iRef. 6]. 
TABLE II-2. PROJECTIONS OF HYDROGEN USE IN METHANOL PRODUCTION

(In Quads)

\begin{tabular}{|c|c|c|c|c|c|c|}
\hline \multicolumn{2}{|c|}{ Reference } & \multirow[t]{2}{*}{$\begin{array}{l}\text { Base } \\
\text { (Year) }\end{array}$} & \multirow[t]{2}{*}{$\begin{array}{l}\text { Estimate } \\
\text { Quantity }\end{array}$} & \multirow[t]{2}{*}{1985} & \multirow[t]{2}{*}{2000} & \multirow[t]{2}{*}{$\begin{array}{l}\text { Assumed Growth } \\
\text { Rate }\end{array}$} \\
\hline (1) & $\begin{array}{l}\text { Jet Propulsion Laboratory } \\
\text { Hydrogen Tomorrow }\end{array}$ & & & & & \\
\hline & $\begin{array}{l}\text { Reference Scenario } \\
\text { Expanded Scenario }\end{array}$ & $\begin{array}{l}(1973) \\
(1973)\end{array}$ & $\begin{array}{l}0.098 \\
0.098\end{array}$ & $\begin{array}{l}0.22 \\
0.58\end{array}$ & $\begin{array}{l}0.61 \\
5.26\end{array}$ & $15.9 \%$ \\
\hline (2) & $\begin{array}{l}\text { Brookhaven National Laboratory } \\
\text { Hydrogen Energy Assessment }\end{array}$ & (1973) & 0.12 & 0.22 & 0.61 & $7 \%$ \\
\hline $\begin{array}{l}\stackrel{H}{H} \\
1 \\
\infty\end{array}$ & $\begin{array}{l}\text { Exxon Research and Engineering } \\
\text { Production Economics... }\end{array}$ & (1975) & 0.06 & 0.11 & 0.23 & $\begin{array}{l}7.7 \%, 1970-1981 \\
5.4 \%, 1980-2001\end{array}$ \\
\hline (4) & $\begin{array}{l}\text { U.S. Bureau of Mines } \\
\text { Mineral Facts and Problems }\end{array}$ & & & & & \\
\hline & $\begin{array}{l}\text { Low } \\
\text { Probable } \\
\text { High }\end{array}$ & (1973) & 0.08 & $\begin{array}{l}0.11 \\
0.12 \\
0.12\end{array}$ & $\begin{array}{l}0.16 \\
0.19 \\
0.20\end{array}$ & $\begin{array}{l}2.5 \% \\
3.1 \% \\
3.4 \%\end{array}$ \\
\hline (5) & $\begin{array}{l}\text { Institute of Gas Technology } \\
\text { Survey of Hydrogen Production }\end{array}$ & (1973) & 0.076 & 0.15 & 0.36 & $6 \%$ \\
\hline$(6)$ & $\begin{array}{l}\text { Institute of Gas Technology } \\
\text { Utilization of Off-Peak Power }\end{array}$ & (1974) & 0.068 & (1990) & 0.12 & $6 \%$ \\
\hline
\end{tabular}


(d) The Bureau of Mines estimate is consistent with production of 1,072 million gallons of methanol in 1973 and an assumed hydrogen requirement of 36 SCF per pound of methanol produced.

(e) The Institute of Gas Technology states their base estimate for Ref. 5 to be from the Bureau of Mines. However, this estimate of hydrogen use is consistent with an estimate of 960 million gallons of methanol produced in 1973 (assuming $36 \mathrm{SCF}$ of hydrogen per pound of methanol produced). The estimate of 960 million gallons appears to have been a preliminary estimate which was later revised to 1,072 million gallons. Their 1974 base estimate for Ref. 6 reflects the recession-induced decline in methanol production.

Thus, JPL overstates actual hydrogen use in methanol production in 1973 by using a capacity rather than a production estimate. On the other hand, Exxon's calculations of hydrogen requirements based on the stoichiometric hydrogen in the methanol molecule probably understate actual hydrogen use. Adjusting for these and the other differences noted, the differences in the base estimates can be reconciled. Since most of the other estimates derive from Bureau of Mines data, the base estimate provided in Mineral Facts and Problems can be assumed to be the basis for projection. future use.

Various lines of reasoning underly the projections of

(a) The JPL reference projection is based on the assumption that: (1) real GNP grows at the same rate as energy growth; and (2) the chemical industry grows at twice the rate of real GNP, based on historical trends. Since the Ford Foundation Technical Fix Baseline scenario used for the reference projection shows energy growth at 3.4 percent a year, the assumptions imply a growth rate for real GNP of 3.4 percent also and a growth rate for the chemical industry of 6.8 to 7 percent. Thus, use of hydrogen in methanol production was projected at 7 percent a year. JPL's Expanded Scenario projects hydrogen use at 15.9 percent, a continuation of the trend from 1968 through 1973, on the assumption that increased uses for methanol will develop.

(b) Brookhaven's base year estimate includes hydrogen used in production of other chemicals as well as of methanol. They assume that hydrogen use in methanol production will "grow at the historical 
rate for chemicals of twice the GNP growth, i.e., $7 \%$ per year." This assumption and Brookhaven's reported estimates appear to be taken directly from the JPL study.

(c) The Exxon study projections of methanol use are taken directly from a Chem Systems, Inc. study, Chemicals from Coal and Shale [Ref. 7]. Methanol production is projected there to grow at an annual rate of about, 7.7 percent between 1970 and 1980 , with the use in formaldehyde, the major use of methanol, growing somewhat slower at 7.4 percent. Between 1980 and 2000, however, use of methanol in formaldehyde production is projected to grow at a rate of 5.9 percent, somewhat faster than the growth rate for the total of 5.4 percent.

(d) The Bureau of Mines projects methanol growth to parallel the growth rate of ammonia. They suggest that "the probable methanol growth rate will continue to be a function of petrochemical development at least until the turn of the century."

(e) IGT calculated an average annual growth rate of 10 percent for methanol production between 1963 and 1973, but actually projected the growth in production at 6 percent, in order to account for the assumed softening of the housing and construction industries slowing the growth of demand for formaldehyde.

Implicitly, these studies assumed that the quantity of hydrogen required per pound of methanol produced will not change significantly from current requirements of 26 to 37 SCF per pound. Moreover, there appears to be general agreement among the studies that the rate of growth for methanol production will be 6 to 7 percent a year, with only the Bureau of Mines projection falling outside that range. This implies hydrogen use of .13 to .14 quads in 1985 and of .31 to .38 quads in 2000 (using a base estimate of .08 quads in 1.977 ).

These projections did not include new uses for methanol, such as for fuel. The conditions for the growth of such new uses for methanol, however, are similar to those which must be met in other new uses of hydrogen; a subject discussed in Chapter IV. 
2. Conditions on the Use of New Hydrogen Production Technologies

The conditions on the use of new hydrogen production technologies in methanol production are similar in major respects to those for ammonia synthesis. The hydrogen required for methanol production, for example, is also supplied through steam reforming of natural gas. Modern low pressure technology for methanol production requires about 100 SCF of natural gas to produce a gallon of methanol. At $\$ 1.50$ to $\$ 2.00$ per 1,000 cubic feet, natural gas accounts for 15 to 20 cents of the total cost of a galion of methanol which now sells for around 44 cents. Increasing costs of acquiring natural gas should therefore heighten the interest of methanol producers in alternative means of producing hydrogen. The economics of alternative technologies are examined in the following chapter.

The requirement for carbon oxides, however, places a constraint on the shift to any new technology to produce hydrogen for methanol production. Natural gas steam reforming provides not only hydrogen but also the carbon required, and carbon must also be supplied with any new technology. IGT points to this problem as a major constraint on the use of utility-supplied hydrogen to produce methanol:

The prospects for the use of utility-supplied hydrogen in methanol synthesis are generally poor. the short term, there seems to be no potential use because of the lack of a readily available source of carbon oxides. On a longer time frame, the economics of the use of hydrogen and by-product carbon dioxide should become more favorable as natural gas costs increase.... In the long range, however, if utility hydrogen becomes competitive with hydrocarbon-reforming processes, ammonia plants would also switch, thereby ending the by-product source of carbon dioxide. The most ilkely feedstock for methanol production in the long run than is coal. [Ref. 6]

On this line of argument, the production of hydrogen for methanol.synthesis would have to occur on site. Where the methanol facility is the only plant being supplied, the scale of the hydrogen production facility would have to be commensurate with the size of the methanol production faciilty. Although the largest methanol plant in the U.S. has a production capacity of 400 million gallons per year, most plants are smaller ( 100 to 200 million gallons per year). At 36. SCF of hydrogen per pound of methanol, these plants have hydrogen requirements of up to 50 billion cublc feet per year or around 130 million cublc feet per day. However, a number of plants for producing methanol are located at the 
same site as an ammonia synthesis plant. Thus, a hydrogen production facility for such a site, scaled to supply both the methanol and ammonia plants, could be built larger in scale than would be the case if the two synthesis plants were separately sited.

\section{Hydrogen in Petroleum Refining}

1. Magnitude of Use and Projected Growth

Hydrogen is used in petroleum refining processes to improve refinery streams and products. In hydrocracking, hydrogen is used to increase the amount of gasoline from crude oil and to improve the quality of the gasoline. In hydrotreating, hydrogen is used to improve the refinery feedstocks by reducing their content of sulfur, nitrogen, and metals.

Table II-3 summarizes estimates from various studies of the current and projected use of hydrogen in petroleum refining. Inspection of the estimates shows clear differences in the base year estimates of hydrogen use, with the Exxon estimate significantly below those of the other studies. Before evaluating the projections of growth, therefore, it is appropriate to examine the reasons for the differences in the base estimates.

The base estimate in the Exxon study [Ref. 3] represents only the hydrogen required for gas oil desulfurization, resid desulfurization, and resid hydrocracking. It is assumed in the Exxon study that the hydrogen required for these processes is manufactured specifically for that purpose in separate hydrogen generators, because of the high hydrogen consumption of the processes and their need for high purity hydrogen. Although hydrogen is also required for desulfurization of light distillate streams, this hydrogen can be supplied as a by-product of the catalytic reforming used to increase the octane number of motor gasoline. In effect, then, the Exxon estimates are for that hydrogen demand in refining which would most likely be supplied by separate hydrogen generation facilities.

In contrast, the base estimates in the studies by JPL, Brookhaven, Bureau of Mines, and IGT are for total hydrogen use in petroleum refining. The estimates differ because of different assumptions about the quantity of oil refined and about the amount of hydrogen required to process a barrel of crude. 
TABLE II-3. PROJECTIONS OF HYDROGEN USE IN PETROLEUM REFINING

(In Quads)

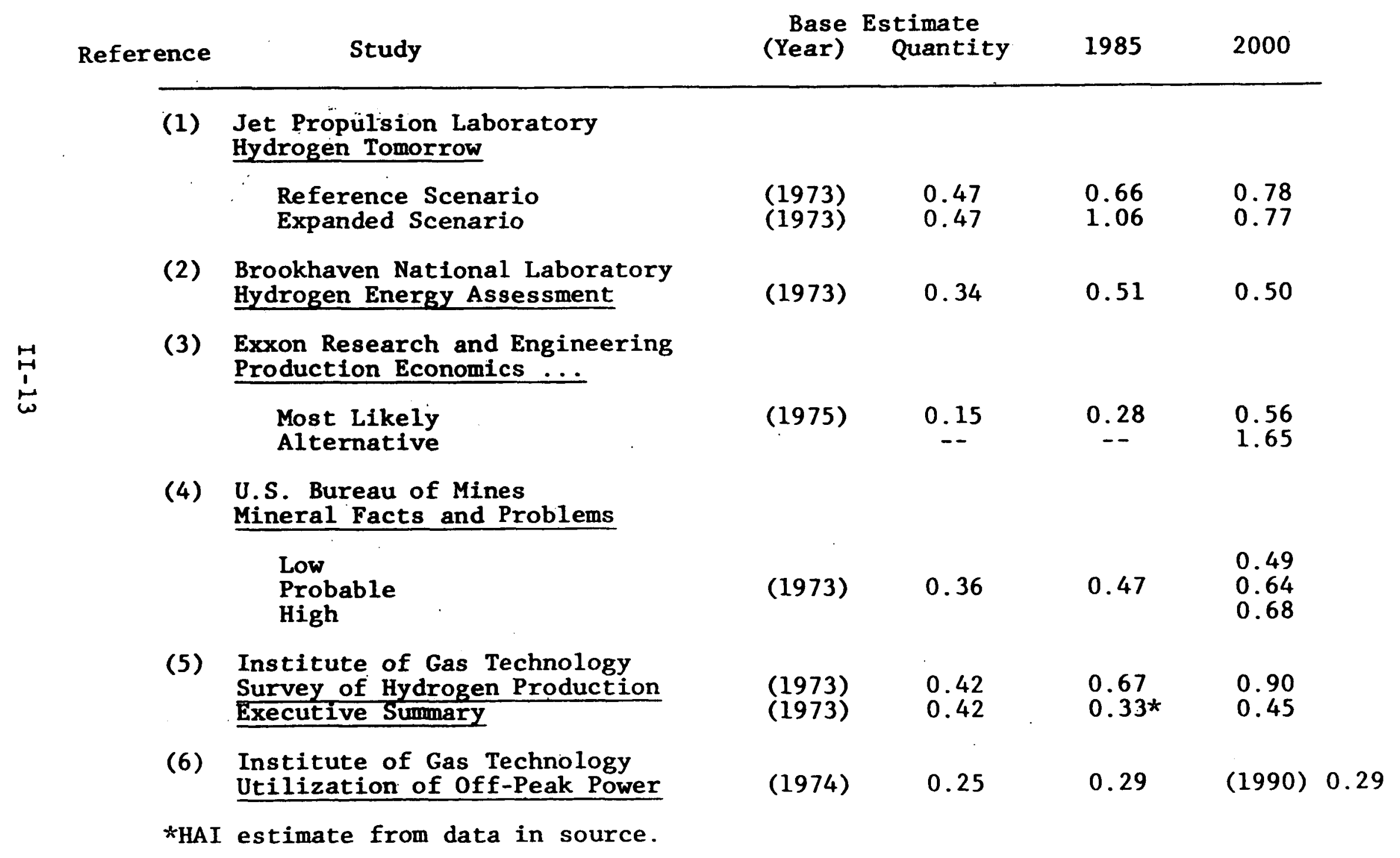


(a) JPL assumes $300 \mathrm{SCF}$ of hydrogen are required to process a barrel of crude. Although their assumption as to the quantity of oil processed in 1973 is not given, using the reported figure on runs to refineries of 4,845 million barrels and multiplying by $300 \mathrm{SCF}$ per billion barrels provides an estimate of $1,453.5$ billion SCF, close to JPL's estimate of 1,434 billion SCF.

(b) Brookhaven assumes $250 \mathrm{SCF}$ of hydrogen are required per barrel of oil. Hydrogen requirements were then computed assuming that all domestic production of crude oil and half of crude imports were used.

(c) The Bureau of Mines assumed that, on average, 250 SCF of hydrogen were required for each barrel of oil hydrotreated and 2,500 SCF for each barrel hydrocracked. The method for calculating hydrogen consumption levels in petroleum refining was not stated explicitly. However, the method used for forecasting suggests that hydrogen use was calculated using hydrotreating and hydrocracking capacities as the basis and adjusting for the level of refinery utilization.

(d) In Ref. 5, IGT calculated hydrogen use in 1973 on the basis of hydrotreating and hydrocracking capacities. Given hydrotreating capacity of 5.78 million barrels per day and assuming 270 SCF of hydrogen required per barrel, hydrogen use of 542 billion cubic feet ( 0.18 quads) for hydrotreating was calculated. Hydrogen use of 742 billion cubic feet ( .24 quads) in hydrocracking was calculated assuming capacity of 855,840 barrels per day and hydrogen requirement of $2,500 \mathrm{SCF}$ per barrel.

(e) In Ref. 6, IGT calculated hydrogen use from responses to a survey. Those refineries responding to the survey, representing 22.1 percent of U.S. hydrotreating capacity, reported hydrogen use for hydrotreating at 46.3 billion cubic feet. Inflated to a U.S. total, this implied hydrogen use in hydrotreating of 210 billion cublc feet. Similarly, refineries representing 31.9 percent of U.S. hydrocracking capacity reported hydrogen use in hydrocracking of 183 billion cubic feet, implying a U.S. total of 574 billion cubic feet. These estimates are, of course, significantly lower than IGT's estimates in Ref. 5. 
Focusing on those uses of hydrogen in petroleum refining which can be supplied by separate hydrogen generators, as is done in the Exxon study, is the best approach for examining the market available for penetration by new hydrogen production technologies. Estimates of total hydrogen use overstate the size of the market avallable to new technologies. That is, since the hydrogen from catalytic reforming is essentialiy costless to use (being a necessary by-product of the process) and since its purity is generaliy adequate for the use made of it, new hydrogen production technologies could hardly be competitive for those uses supplied by hydrogen from catalytic reforming. However, new production technologies might become competitive against steam reforming of natural gas for use in resid hydrocracking, resid desulfurization, and gas oil desulfurization.

The projections of future growth in hydrogen use reflect, of course, the same assumptions as were used in deriving base estimate. Thus, the projections by JPL, Brookhaven, Bureau of lines and IGT are all for total hydrogen use and are based on assumed growth rates either for crude oil production or for refinery capacity.

(a) JPL's reference projection is based on the Ford Foundation Technical Fix scenario projections of oil supply. The expanded scenario projection assumes the hydrogen required to process a barrel of crude o1l increases from 300 SCF to 610 SCF.

(b) Brookhaven's projection 18 based on an ERDA projection of oil demand declining between 1985 and 2000 because of "moderate energy conservation efforts, the implementation of the new car mileage efficlency regulations and moderate penetration of new energy technologies."

(c) The Bureau of Mines profections are based on projected growth in hydrocracking and hydrotreating capacity. The probable case assumes petroleum capacity will grow at 2.2 percent to the year 2000. The low growth profection, at 1.2 percent a year, assumes a low demand growth for petroleum and $a$ drop in the hydrogen requirement per barrel of oll processed. A more optimistic assumption about the supply of crude oll underlies the high projection, with a growth rate of 2.5 percent a year: 
(d) For the projection presented in the body of their report, IGT [Ref. 5] assumed that hydrotreating capacity would grow at a rate of 10 percent a year until 1979 and afterward would grow at the rate of refining capacity in general, assumed to be about 2 percent. Simliarly, it is assumed that hydrocracking capacity grows at the same rate as oil refining in general after 1980 . No explanation is given for the difference in estimates between Volume $I$; Executive Summary, and Volume 2, Discussion.

(e) In Ref. 6, IGT assumed use of hydrogen in hydrocracking would increase at less than 1 percent to 1980, with no growth between 1980 and 1990 . Hydrogen use in hydrotreating was projected to grow at 8 percent to 1980 and to cease between 1980 and 1990. However, IGT also projected the demand for outside hydrogen, assuming that this demand would grow at 3 percent a year from a 1974 level of 250 billion cubic feet (.08 quads).

There is relatively little question that, as assumed in these studies, the petroleum refining industry will grow at a low rate in coming years. The growth rates they assume are consistent with other projections of growth in U.S. petroleum demand. The more interesting question concerns the rapid rate of growth in hydrogen demand projected in the Exxon study, since, as was noted above, their definition of hydrogen use better relates to the potential market for new production technologies.

Table II-4, reproduced from the Exxon report, shows their projections of hydrogen requirements in U.S. refineries. It is clear that desulfurization of gas oil and resid accounts for much of the projected growth in hydrogen demand. The rapid growth projected by Exxon, however, is consistent both with current trends and with projections by other sources.

Production of residual fuel oil as a percentage of total refinery output has increased in recent years, from 6.1 percent in 1970 to 9.7 percent in 1976. At the same time, the crude oil being input to refineries is of increasingly higher sulfur content, necessitating desulfurization of the residual oil and gas oil. As a reflection of this, the capacity of refineries for hydrotreating gas oils and resid has increased from 160 thousand barrels per day at the beginning of 1975 to 515.1 thousand barrels per day at the beginning of 1978 . 
TABLE II-4. U.S. REFINERY HYDROGEN REQUIREMENTS

(million SCF/CD)

\begin{tabular}{|c|c|c|c|c|c|c|}
\hline Process & 1977 & 1980 & 1985 & 1990 & $\begin{array}{c}\text { Most } \\
\text { Likely } \\
2000 \\
\end{array}$ & $\begin{array}{c}\text { Alternate } \\
2000 \\
\end{array}$ \\
\hline Gas oll desulfurization & -- & 424 & 672 & 1,127 & 1,925 & 1,610 \\
\hline Resld desulfurization & 120 & 210 & 210 & 385 & 600 & 2,850 \\
\hline Resid hydrocracking & 1,265 & 1,150 & 1,522 & 1,746 & 2,200 & 9,600 \\
\hline Total & 1,385 & 1,784 & 2,404 & 3,258 & 4,725 & 14,060 \\
\hline
\end{tabular}

Source: Ref. 3

Other projections also suggest a rapid increase in hydrotreating of gas oil and residual oil. Table II-5 for example, shows the demand for hydrogen for the hydrotreating of gas oil and for resid as projected by the Pace Company.

A.D. Little has also projected that:

...growing fuel oil demand, particularly for low sulfur fuels in the wake of declining domestic natural gas production, [will] create the need for further desulfurization capacity. The trend will be accentuated by the declining production of sweet [i.e., low sulfur] U.S. crude oil which must be replaced by either sour North Slope or Middle East crudes. [Ref. 19]

TABLE II-5. HYDROGEN REQUIREMENTS FOR HYDROTREATING (million SCF/SD)

\begin{tabular}{crrrr} 
Process & 1977 & 1980 & 1985 & 1990 \\
\hline Gas oil sulfurization & 210 & 250 & 210 & 440 \\
Resid desulfurization & -- & 30 & 110 & 210 \\
\hline
\end{tabular}

Source: Ref. 18 
In short, there is support for the Exxon profection that the demand for hydrogen in petroleum refining will grow rapidly in coming years.

\section{Conditions on Hydrogen Use in Petroleum Refining}

The sensitivity of the demand for hydrogen in petroleum refining to the cost of producing the hydrogen depends on the processes being considered. On one hand, there are few process alternatives to hydrotreating for desulfurization of refinery streams. Although chemical treatments can modify the form of the sulfur compounds, and although absorbers might remove some of the undesirable components, the sulfur would not be removed from the petroleum, causing reduced ylelds of the more desirable products. Consequently, the demand for hydrogen in hydrotreating should show little sensitivity to the cost of hydrogen within a fairly broad cost range.

On the other hand, there are processes alternative to hydrocracking of residual o1l. As pointed out in the Exxon study:

Residuum processes can be characterized as elther carbon removal processes, e.g., coking, or hydrogen addition processes, 1.e., hydrocracking.... The cholce between these two alternative processing methods depends on specific economic factors.... [Ref. 3]

Accordingly, Increased costs of producing hydrogen would reduce the economic competitiveness of hydrocracking. vis-avis carbon removal processes. The demand for hydrogen in hydro-cracking should therefore be sensitive to changes in the cost of producing hydrogen.

Hydrocracking and hydrotreating processes for residual o1ls and heavy gas olls require hydrogen with a purity of 95 percent or more. This requirement has precluded the use of the by-product hydrogen produced in catalytic reforming, which is generally of 70 to 80 percent purity. Therefore, separate hydrogen generators supplying hydrogen for hydrocracking and for hydrotreating must be capable of producing relatively high purity hydrogen.

Petroleum refining processes are operated on a continuous basis. The hydrogen supply therefore must also be continuous to ensure that the continuity of the refining process is not interrupted. 
As the earlier discussion noted, the steam reforming of methane to produce hydrogen for ammonia synthesis also provides the nitrogen required, and methanol synthesis requires that a carbon source be supplied with the hydrogen. However, similar conditions do not seem to apply in hydrocracking or hydrotreating processes, where hydrogen alone is sufficient. Moreover, as the use of separate hydrogen generators illustrates, the source of the hydrogen supplied can be external to the refinery processes. That is, these conditions suggest that the hydrogen need not be produced and consumed "captively" but could be supplied as merchant hydrogen.

Where a hydrogen generator is constructed solely to supply hydrogen to a given refinery, then the scale of the hydrogen production facility must be commensurate with the scale of hydrogen demand from the refinery. Currently, the maximum scale of refinery demand for externally supplied hydrogen is about 135 million SCF per day, with only one refinery having a hydrogen generator of this size. Generally, the level of demand is $100 \mathrm{million}$ SCF per day or less [Ref. 3]. Under current environmental, economic, and regulatory policies, there appears to be little probability that the scale of U.S. refineries, and hence the scale of their demand for externally supplied hydrogen, will increase much. However, such constraints on the scale of the hydrogen production facility need not occur if the refineries can be supplied with merchant hydrogen. One obvious condition that would have to be met for supplying merchant hydrogen to refineries to become a viable option is that the cost to the refinery of purchasing hydrogen be economically competitive with the costs of the refinery owning and operating its own hydrogen generator. The costs of producing hydrogen are examined in Chapter III.

\section{Specialty Uses of Hydrogen}

Besides the major uses of hydrogen discussed in the previous sections, there is a miscellany of smaller scale, specialty uses of hydrogen. Included in this grouping are uses of hydrogen for hydrogenation of fats and oils, for reduction of metal ores, for metal-treating atmospheres, as well as numerous other uses.

Projections for the use of hydrogen in the various specialty uses are presented in Table II-6. The estimates differ because of differences in the uses considered and differences in growth rate assumptions. 
TABLE II-6. PROJECTIONS OF HYDROGEN USE IN SPECIALTY USES

(In Quads)

\begin{tabular}{|c|c|c|c|c|c|c|}
\hline & Study & $\begin{array}{l}\text { Base } \\
\text { (Year) }\end{array}$ & $\begin{array}{l}\text { Estimate } \\
\text { Quantity }\end{array}$ & 1985 & 2000 & $\begin{array}{c}\text { Assumed Grow } \\
\text { Rate }\end{array}$ \\
\hline \multirow[t]{2}{*}{ (1) } & $\begin{array}{l}\text { Jet Propulsion Laboratory } \\
\text { Hydrogen Tomorrow }\end{array}$ & & & & & \\
\hline & $\begin{array}{l}\text { Reference Scenario } \\
\text { Expanded Scenario }\end{array}$ & $\begin{array}{l}(1973) \\
(1973)\end{array}$ & $\begin{array}{l}0.07 \\
0.07\end{array}$ & $\begin{array}{l}0.22 \\
0.40\end{array}$ & $\begin{array}{l}0.65 \\
1.30\end{array}$ & $\begin{array}{l}\text { See Text } \\
\text { See Text }\end{array}$ \\
\hline (2) & $\begin{array}{l}\text { Brookhaven National Laboratory } \\
\text { Hydrogen Energy Assessment }\end{array}$ & (1973) & 0.04 & 0.10 & 0.25 & See Text \\
\hline \multirow{3}{*}{$\begin{array}{l}\text { (3) } \\
\text { (4) }\end{array}$} & $\begin{array}{l}\text { Exxon Research \& Engineering } \\
\text { Production Economics... }\end{array}$ & (1975) & 0.02 & 0.04 & 0.08 & $5 \%$ \\
\hline & $\begin{array}{l}\text { U.S. Bureau of Mines } \\
\text { Mineral Facts and Problems }\end{array}$ & & & & & \\
\hline & $\begin{array}{l}\text { Low } \\
\text { Probable } \\
\text { High }\end{array}$ & (1973) & 0.03 & 0.07 & $\begin{array}{l}0.09 \\
0.16 \\
0.34\end{array}$ & See Text \\
\hline (5) & $\begin{array}{l}\text { Institute of Gas Technology } \\
\text { Survey of Hydrogen Production }\end{array}$ & (1973) & 0.05 & 0.15 & 0.30 & See Text \\
\hline (6) & $\begin{array}{l}\text { Institute of Gas Technology } \\
\text { Utilization of Off-Peak Power }\end{array}$ & (1974) & 0.03 & 0.06 & $\begin{array}{c}(1990) \\
0.08\end{array}$ & See Text \\
\hline
\end{tabular}


(1) The estimates presented in Table II- 6 from the JPL study represent the sum of their estimates for hydrogenation of oils, for direct reduction of ores, and for miscellaneous uses. In the reference scenario, hydrogenation of fats and oils and miscellaneous uses were projected to grow at 7 percent a year; direct reduction was projected to reach 0.06 quads by 1985 and to grow at about 9 percent a year from then until 2000. In the expanded production scenario, use of hydrogen for hydrogenation of fats and oils was projected at its highest historical growth rate of 6.4 percent and miscellaneous use at its 1964 to 1973 growth rate of 8.7 percent. Hydrogen was projected to be used in direct reduction of 11 percent of metalilc ore in 1985 and of 25 to 30 percent in 2000, with an implied growth rate of about 7.8 percent.

(2) The estimates from the Brookhaven study represent the sum for hydrogenation of fats and oils, for ore reduction and for other uses. Hydrogenation of fats and oils and other uses were projected to grow at 7 percent a year, while ore reduction was projected at 2.7 percent.

(3) The Exxon estimates are based on Bureau of the Census data on small uses of hydrogen. A growth rate of 5 percent was assumed in projecting future levels of use.

(4) The Bureau of Mines estimates represent the sum of hydrogenation of fats and oils, of liquid hydrogen, of direct reduction and of other uses. Hydrogenation of fats and oils were projected to grow at less than 3 percent, but other uses were projected at 6.9 percent. Use of hydrogen in direct reduction was projected to grow at about 8.5 percent from 1973 to 1985 and at about 5.5 percent from 1985 to 2000 .

(5) In their Survey of Hydrogen Production, IGT projected growth in the miscellaneous uses of hydrogen. at 10 percent until 1985 and at 5 percent after that. The estimate shown for their study on the utilization of off-peak power represents the sum of hydrogen used for lon ore reduction, for fats and oils, and for other uses. Hydrogen use in iron ore reduction was projected to grow at 17 percent until 1980 and at 10 percent thereafter. Hydrogeneration of fats and oils was projected to grow at 2 percent, with other uses growing at 5 percent overall. 
Given the variety of these small scale uses, a variety of growth rates can be possible. Recent Bureau of the Census data show that production of hydrogen for small uses has increased at an average of 8.7 percent a year since 1972 . Thus, projections of future growth in these small uses at 5 to 7 percent a year do not appear to be unduly optimistic.

\section{E. Probable Market Growth}

Based on the discussion in the proceding sections, Table II-7 presents the most likely estimates of future hydrogen use in existing applications. 
TABLE II-7. HYDROGEN USE IN CHFMICAL APPLICATIONS

(In Ouads)

\begin{tabular}{|c|c|c|c|c|c|}
\hline Use & 1973 & 1977 & 1985 & 2000 & $\begin{array}{c}\text { Expected Growth } \\
\text { Rate }\end{array}$ \\
\hline Ammonia Synthesis & 0.33 & 0.38 & $0.49-0.50$ & $0.77-0.82$ & $3.1 \%-3.4 \%$ \\
\hline Methanol Production & 0.08 & 0.08 & 0.13 & 0.31 & $6.0 \%$ \\
\hline Petroleum Refining & -- & 0.17 & 0.28 & 0.56 & $5.3 \%$ \\
\hline $\begin{array}{l}\text { Specialty uses } \\
\text { (e.g., hydrogenation of } \\
\text { fats and oils, reduction } \\
\text { of nonferrous metals, } \\
\text { metal-treating atmospher }\end{array}$ & $\begin{array}{l}0.03 \\
\text { res) }\end{array}$ & 0.03 & $0.04-0.05$ & $0.09-0.14$ & $5.0 \%-7.0 \%$ \\
\hline
\end{tabular}




\section{REFERENCES}

\section{Chapter II}

1. Kelley, J. and Laumann, E. Hydrogen Tomorrow, Demands and Technology Requirements (Pasadena, Cal.: Jet Propulsion Laboratory, 1975)

2. Salzano, F.J. and Braun, C., eds. Hydrogen Energy Assessment (Upton, N.Y.: Brookhaven National Laboratory, 1977).

3. Corneil, H.G., Heinzelmann, F.J.; and Nicholson, E.W.S. Production Economics for Hydrogen, Ammonia and Methanol During the 1980-2000 Period (Linden, New Jersey: Exxon Research and Engineering Company, 1977).

4. U.S. Bureau of Mines. Mineral Facts and Problems, 1975 ed. (Washington, D.C.: U.S. Government Printing Office, 1976).

5. Gillis, J.; Gregory, D.P.; and Pangborn, J.B. Survey of Hydrogen Production and Utilization Methods (Chicago, Illinois: Institute of Gas Technology, 1975).

6. Biederman, N.; Darrow, K., Jr.; and Konopka, A. Utilization of Off-Peak Power to Produce Industrial Hydrogen (Chicago, Illinois: Institute of Gas Technology for the Electric Power Research Institute, 1975).

7. Chem Systems, Inc. Chemicals from Coal and Shale-An R\&D Analysis for National Science Foundation (New York: 1975).

8. Mayo, H.C. and Finneran, J.A. "Capacity Surge, Story of Ammonia," Oil and Gas Journal, March 18, 1968.

9. U.S. Bureau of the Census, Statistical Abstract of the United States: 1977 ( 98 th edition), Washington, D.C., 1977, p. 676 .

10. Greek, B.F. and Tollwell, W.F. "Gas-Based Chemicals: slow growth continues", Chemical and Engineering News, January 9, 1978 .

11. Davis, J.R. "Are bigger plants better? No small debate", Chemical Engineering, May 22, 1978.

12. "Fertilizer Imports Bolster Fertilizer Exports," Chemical Week, January 11, 1978. 
13. "Another Big Year for Fertilizer Markets," Chemical Week, August 3, 1977.

14. "Fertilizer Leaders See Energy as Fast-Growing Cost Element," Chemical Marketing Reporter, September 26, 1977.

15. Dickson, E.M.; Ryan, J.W.; and Simulyan, M.H. The Hydrogen Energy Economy (New York: Praeger Publishers, 1977).

16. Nichols, D.E. and Blouin, G.M. "Economic Considerations of Chemical Nitrogen Fixation" Paper presented at 1977 Annual ACS Meeting, Chicago, Illinois, August 28September 2, 1977.

17. Buividas, L.J.; Tinneran, J.A.; and Quartulli, O.J. "Alternate Ammonia Feedstocks", Chemical Engineering Progress, October 1974.

18. Paper presented at Workshop on Supply and Demand of Hydrogen as a Chemical Feedstock, University of Houston, December, 1977.

19. Arthur D. Little, Inc. Assessment of Fuels for Power Generation by Electric Utility Fuel Cells, EPRI Report EM-695, March, 1978. 
This chapter surveys and evaluates the estimates of the costs of producing hydrogen with different technologies.

The first section provides a brief description of the technology and economics of producing hydrogen through catalytic reforming of natural gas. Following sections survey and evaluate the costs of producing hydrogen through coal gasification and through electrolysis. The economics of production with these technologies depend fundamentally on the cost and availability of feedstocks and utility power, and on the capital costs of the production facility. These factors are discussed in each section. A final section compares the alternative methods of producing hydrogen.

\section{A. Hydrogen Production from Natural Gas}

Most of the hydrogen now used in the U.S. is produced through steam reforming of natural gas. Thus, the technology and economics of producing hydrogen from natural gas provide the basis against which to compare other technologies for producing hydrogen.

The steps in the production of hydrogen from natural gas are illustrated in Figure III-1. The natural gas is first desulfurized to prevent poisoning of the reformer catalyst. It is then reacted with superheated steam over a nickel catalyst in a reformer. This reaction is highly endothermic and requires a considerable amount of natural gas to provide the heat. Additional hydrogen is formed by a shift-conversion of all of the carbon monoxide to carbon dioxide. The carbon dioxide is then removed from the shift conversion, residual carbon dioxide and carbon monoxide are removed by methanation, and the hydrogen is compressed to the required pressure.

The costs of producing hydrogen from natural gas are shown in Figure III-2 for various scales of plant and for different prices of natural gas. The costs are for 1980 (1980 \$). These cost estimates, prepared by Chem Systems, Inc., as part of this study, were estimated in the same way as costs were calculated for the Exxon study [Ref. 1]. 


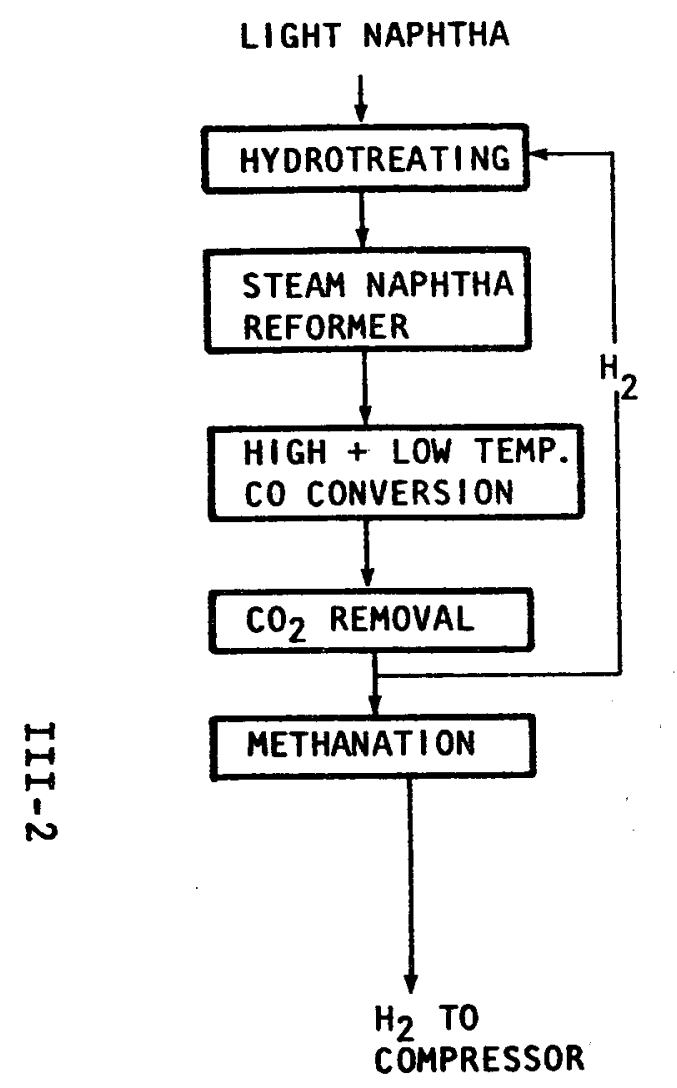

(a)

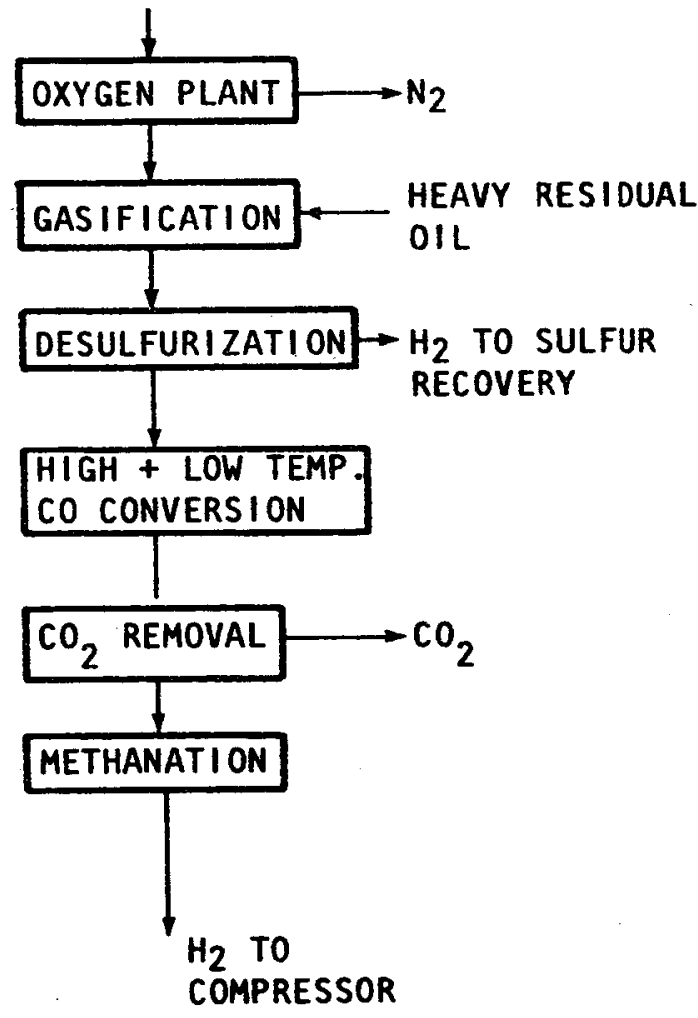

(b)

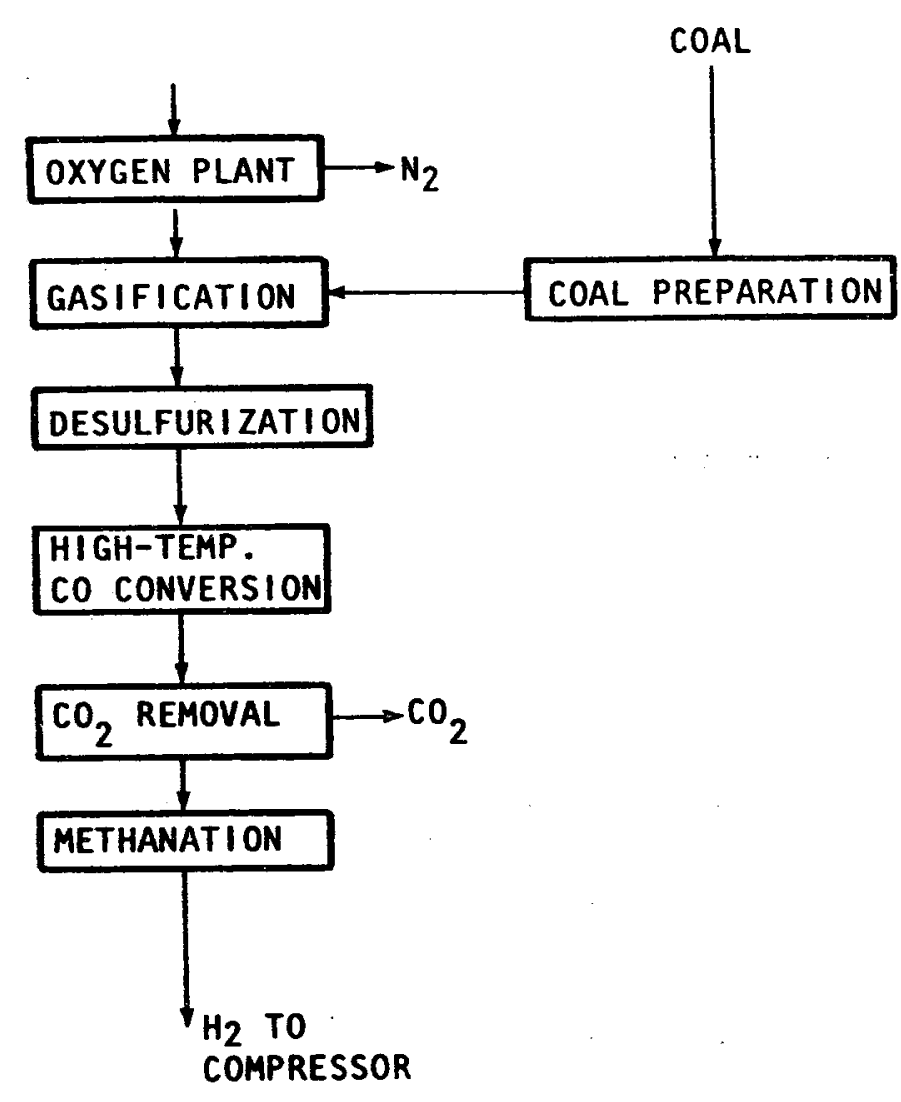

(c)

Figure III-1. Hydrogen Production Processes: (a) Steam Reforming (b) Partial Oxidation of Residual Oil (c) Partial Oxidation of Coal 


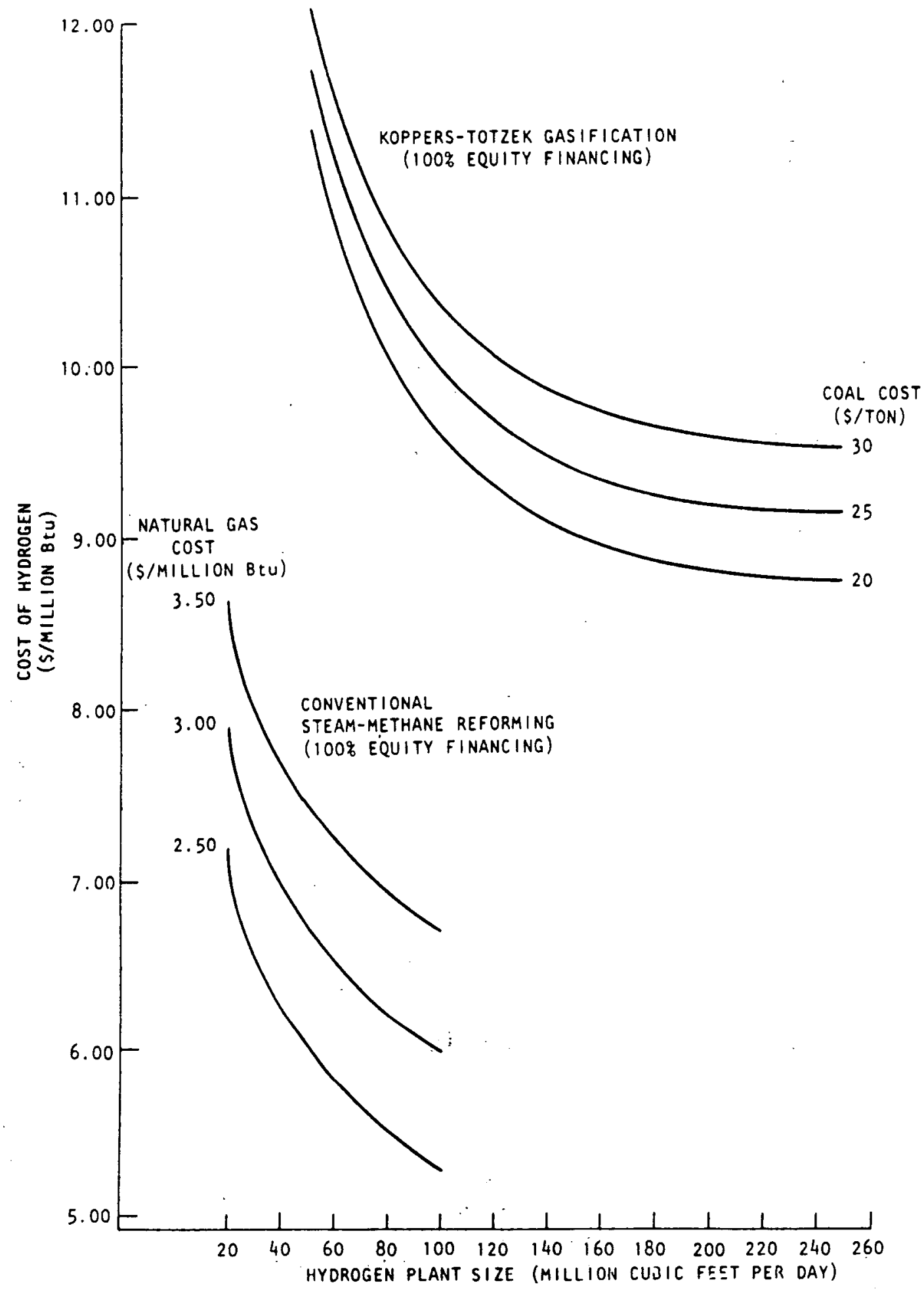

Figure III-2. Comparative Cost of Producing Hydrogen Steam-Methane Reforming vs. Coal Gasification, 1980 \$ 


\section{B. Hydrogen Production Through Coal Gasification}

1. Technological Options

There are several coal gasification processes in existence (Lurgi, Koppers-Totzek, Winkler) or under development [by Texaco, by Shell and Koppers-Totzek, and by the Institute of Gas Technology (IGT)] which might be used to produce hydrogen. The steps involved in producing hydrogen through coal gasification are illustrated in Figure III-1.

Coal is first milled or crushed to the proper size and dried. It is then introduced into the gasifier, along with steam and air or oxygen, the steam being the basic source of the hydrogen produced through coal gasification. The reaction of carbon with steam in the gasifier generates a synthesis gas of hydrogen and carbon monoxide. As in natural gas reforming, this reaction is highly endothermic, with the required heat being supplied by the reaction of coal with air or oxygen. The composition of the synthesis gas generated depends on the temperature and pressure within the gasifier. A high temperature, low pressure operation generates a synthesis gas relatively rich in hydrogen and carbon monoxide, while a low temperature, high pressure operation generates a gas relatively rich in methane. The synthesis gas is then desulfurized and passed through a shift conversion process. Carbon dioxide removal, methanation, and compression then follow.

The equipment required for these steps, and the conditions under which the processes operate, are basic determinants of the costs of producing hydrogen. Comparing the steps for producing hydrogen through coal gasification to those for producing hydrogen from natural gas, it can be seen that several items of equipment are different. The coal gasifiers replace the two-stage reformer used in the natural gas process, and coal handling and preparation and ash disposal systems are required. An air separation or oxygen plant is required to provide the necessary oxygen for the gasification process. Finaliy, gas scrubbers are needed not only for the removal of carbon monoxide but also for the removal of hydrogen sulfide. Because of these changes in equipment, $1 t$ is estimated that the investment for a coal gasification plant would be about twice that for a natural gas-reforming plant.

Operating characteristics for several coal gasification processes are illustrated in Table III-1. The gasifiers are classified as fixed-bed, fluidized-bed, or entrained-bed, according to the type of gas-solid contact used. 
TABLE III-1. COAL GASIFICATION PROCESSES

FOR HYDROGEN PRODUCTION OPERATING CHARACTERISTICS

Lurg1 W1nkler Kopper8-Totzek Texaco

\begin{tabular}{|c|c|c|c|c|}
\hline $\begin{array}{l}\text { Type of } \\
\text { gasifters }\end{array}$ & Fixed fuel bed & Fluidized-bed & Entrained & Entrained \\
\hline Pressure & Up to $425 \mathrm{ps} 18$ & $\begin{array}{l}\text { S11ghtly over } \\
\text { atmosphertc }\end{array}$ & $\begin{array}{l}\text { Slightly } \\
\text { over } \\
\text { atmospher1c }\end{array}$ & $365 \mathrm{pg} 18$ \\
\hline $\begin{array}{l}\text { Tempera- } \\
\text { ture }\end{array}$ & $1200-1400^{\circ} \mathrm{F}$ & $1300-1900^{\circ} \mathrm{F}$ & $2400-3000^{\circ} \mathrm{F}$ & $400^{\circ} \mathrm{F}$ \\
\hline $\begin{array}{l}\text { Tons of } \\
\text { oxygen per } \\
\text { ton coal. }\end{array}$ & 0.3 & 0.5 & $0.65-0.80$ & $0.9-0.9$ \\
\hline $\begin{array}{l}\text { Lbs of } \\
\text { steam per } \\
\text { ton dried } \\
\text { coal }\end{array}$ & $2000-5000$ & 50 & $250-600$ & $200-1200$ \\
\hline $\begin{array}{l}\text { Gasifier } \\
\text { efflelency }\end{array}$ & $65-75 \%$ & $55-65 \%$ & $65-75 \%$ & $77 \%$ \\
\hline
\end{tabular}

(a) Fixed-bed gasifiers, such as the Lurgi gasifier, require coal of uniform size which does not degrade or break apart during gasification, or cake, or agglomerate. Since the temperature for fixedbed gasiflers must be kept low to prevent caking, the gas produced is relatively rich in methane.

(b) Entrained-bed gasifiers, such as the KoppersTotzek and Texaco, can use any size coal, since the coal particles are carried in with the oxygen and steam streams. This type of gasifler tends to operate at higher temperatures and consequently produces a gas which is relatively rich in hydrogen and carbon monoxide. Moreover, operation at higher temperatures causes fewer tars, phenols, and high hydrocarbons to form.

(c) Fluidized-bed gasiflers, such as the Winkier gasifler, have rperating characteristics between those of the flxed-bed and entrained-bed gasifiers. Since the coal particles are fluldized, the feed coal must be uniform in size to keep the bed stable. 
The constraints on the coal handling and preparation equipment are less severe with entrained-bed gasifiers. The coal can either be fed by a variable speed screw feed (as with the Koppers-Tozek gasifier) or be slurried and blown into the gasifier (as with the Texaco gasifier).

The process variables -- pressure, temperature, residence time, steam-to-coal ratio, oxygen-to-coal ratio -affect both the investment and the operating costs of the different coal gasification processes. For example, higher pressures tend to increase gasification rates, thereby permitting increased throughput of coal. Heat losses per unit of gas produced are also reduced, improving efficiency. Moreover, the costs of compressors are a significant element of the investment cost of low pressure gasification processes; processes operating at high pressures can therefore have lower investment costs because of lower costs for compressors and the high productivity of the gasifier. The effects of higher temperatures are to decrease the formation of methane and other hydrocarbons, to increase reaction rates, and to increase coal throughput. However, in operating at high temperatures, more oxygen is required for heat generation reactions in the gasifier.

Although Lurgi technology has been proposed for most syngas-from-coal projects in the United States, the entrained-bed gasifiers (Koppers-Totzek and Texaco) appear to be more favorable for the production of hydrogen. KoppersTotzek gasification, for example, has been used for a number of years in other countries to produce hydrogen for ammonia synthesis. The Texaco process has been chosen by the Tennessee Valley Authority for an experimental coal-toammonia plant.

The Koppers-Totzek Process has several advantages:

(a) Versatility - The process is capable of continuous operation for the gasification of a variety of feedstocks, including coal, char, petroleum coke, tars, heavy residuals, light to heavy oils, and pumpable slurries of carbonaceous materials in liquid hydrocarbons.

(b) Flexibility - The change-over from solid to liquid feeds involves only a change of burner heads. Multiple feed burners permit wide variations in turn-down ratios. The process is capable of instantaneous shutdown with full production resumed in 30 minutes. 
(c) Environmental Control - The process is essentially pollution-free. Gasification products are clean gas (free from tars, condensable hydrocarbons, ammonia and phenol) and slag.

(d) Simplicity of Construction - No complicated precision mechanical equipment or pressure sealing devices are required. The only moving parts at the gasifier are screw feeders for solids or pumps for liquid feedstocks.

(e) Low Maintenance

(f) High Capacity - 850 tons per day

(g) Safe and Efficient - The Koppers-Totzek process has over 20 years of safe operation. The onstream time is better than 95 percent. Gasifier overall thermal efficiency is 85 percent.

The advantages of the Texaco process are:

(a) Versatility - Accepts a variety of U.S. coals, char, petroleum coke, tars, heavy residuals, and pumpable slurries of carbonaceous materials in liquid hydrocarbons.

(b) Applicability - Produces a gas compatible with ammonia processes and operates at pressures compatible with ammonia processes.

(c) Environmental Control - Avoids gas contaminants such as tars, oils, and phenols, and avoids byproducts such as char.

(d) Reliability - Uses U.S.-based technology, methods, and equipment.

(e) Commercial Applications - Has a short lead time, with commercial operation expected by 1983.

Both the Koppers-Totzek process and the Texaco process have relatively minor environmental impacts. The high operating temperatures of the Koppers-Totzek and Texaco gasifiers result in gas containing only about 0.1 percent methane and no detectable amounts of higher hydrocarbons or coal distillation products. This is an advantage in view of the strict effluent regulations that may be required.

Hydrogen cyanide, said to be dependent upon the ash composition, is present in the Koppers-Totzek raw gas stream 
in small amounts. The $H C N$ content could be as high as 40 ppm. This is removed by scrubbing with water, the bottoms stream from the scrubber then passing with the water to the slimes dams. The coal ash, which contains $\mathrm{Fe}_{2} \mathrm{O}_{3}$, reacts with HCN so that the water from the slimes dams contains less than $1 \mathrm{ppm}$ of $\mathrm{HCN}$.

The slimes dams prove equally effective in removing the traces of ammonia absorbed from the raw gas by the circulating wash water, the dam effluent containing a maximum of $15 \mathrm{ppm} \mathrm{v} / \mathrm{v}$ of ammonia.

Combustible sulfur in coal appears as $\mathrm{H}_{2} \mathrm{~S}$ and $\operatorname{COS}$ in the raw gas; $\mathrm{H}_{2} \mathrm{~S}$ and $\mathrm{COS}$ are absorbed in an acid gas removal process and then regenerated as a by-product gas. This gas stream, along with carbon dioxide, is sent to a sulfur recovery process where elemental sulfur is recovered. A tail gas treatment may be necessary to reduce $\mathrm{SO}_{\mathrm{x}}$ emissions from the sulfur recovery process.

Proper disposal of the slag from the gasifiers is required to prevent any leachate problems. Landfilling at a coal mine may be a suitable disposal method.

Coal particulates from coal preparation and fugitive emissions resulting from the plant operation also require a proper control.

Water runoff from coal storage areas or from the use of water sprays for dust suppression is another environmental problem. This water is treated by lime treatment in a pond before being discharged.

Control technology cost for a coal gasification plant for hydrogen generation w1ll be about 5 to 8 percent of the total capital cost.

\section{Cost of Hydrogen from Coal}

a. Survey of Studies. The costs of producing hydrogen from col will depend not only on the process which is used, but also on the size of the plant, the cost of feedstocks and utilities, and the plant location. Table III-2 summarizes estimates of the cost of hydrogen from coal which have been derived in a number of studies and shows the as sumptions on which the estimates are based. Inspection of the table reveals considerable heterogenelty among studies in the assumptions used. Nevertheless, several broad conclusions can be drawn from the estimates. 


\section{TABLE III-2. ESTIMATES OF THE COST}

OF HYDROGEN FROM COAL

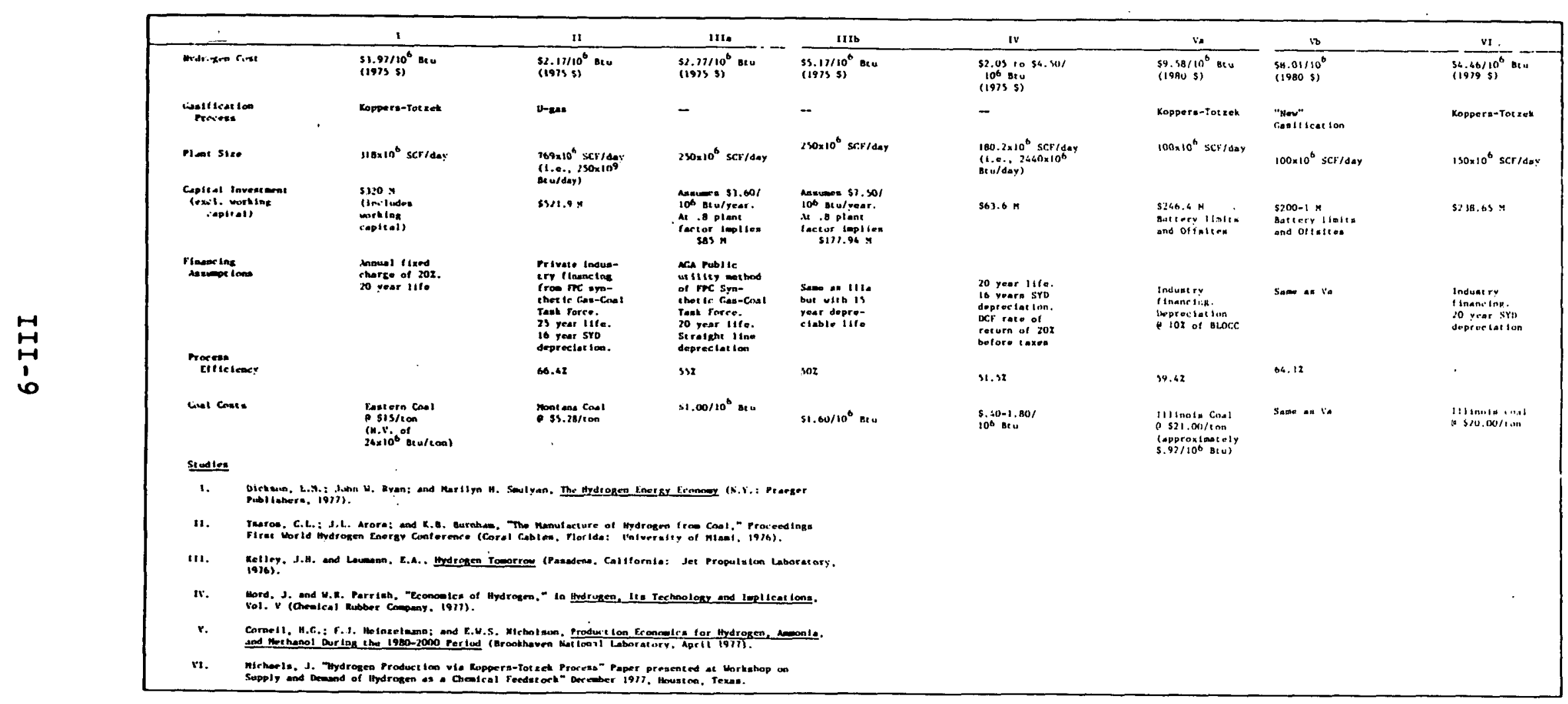


First, the various estimates confirm that the costs of producing hydrogen from coal are dominated by the capital costs associated with the investment in the plant and equipment. With efficiencies of 50 percent or better assumed in all of the studies, and with coal prices at $\$ 1.00$ per million Btu, coal costs account for about $\$ .50$ of the estimated costs of producing hydrogen. It is clear that this is no more than 20 percent of the total cost estimated in most of the studies.

Given that the cost of producing hydrogen from coal is determined primarily by the investment in the plant and equipment, it would be desirable to reconcile the assumptions concerning capital costs in the various studies to arrive at a best estimate of the costs of producing hydrogen. However, the nature of the studies precludes that reconciliation. Descriptions and cost estimates are generally not given for the various items of equipment included in the investment cost. Further complications arise because of the significant variation in the assumptions concerning the size of the plant being considered and the method of financing.

Most of the studies summarized in Table III-3 assumed scales of plant noticeably beyond the range of typical hydrogen use in current ammonia plants, petroleum refineries or other hydrogen-using facilities. The typical range of use in ammonia plants, for example, is 36 to 105 million SCF of hydrogen per day, and in petroleum refineries typical use ranges up to 70 million SCF per day. The ratio of plant investment costs between a large plant and a small plant is generally less than the ratio of their capacities. Assuming a large scale plant for the purposes of cost estimating would lead to relatively low estimates of capital costs per ton of capacity. Hence, many of the cost estimates for hydrogen in Table III-3 appear to be on the low side. Moreover, estimating the costs of hydrogen production for plants of the scale assumed in most of the studies leaves unanswered the question of how the hydrogen is to be used, since it is clear that the output of a large plant would far exceed the current requirements of any hydrogen-using facility.

The second assumption of note in most of the studies concerns the method of financing. Some of the studies have used "utility" financing while others have used "private industry" financing. There are basic differences in the results under the calculation procedures for each of these financing methods. In general, the utility financing approach implies a lower cost of obtaining capital than does the private industry financing approach. Since coal gasification plants producing hydrogen would be highly 
TABLE III-3. PROJECTIONS OF NATURAL GAS PRICES \$/MCF

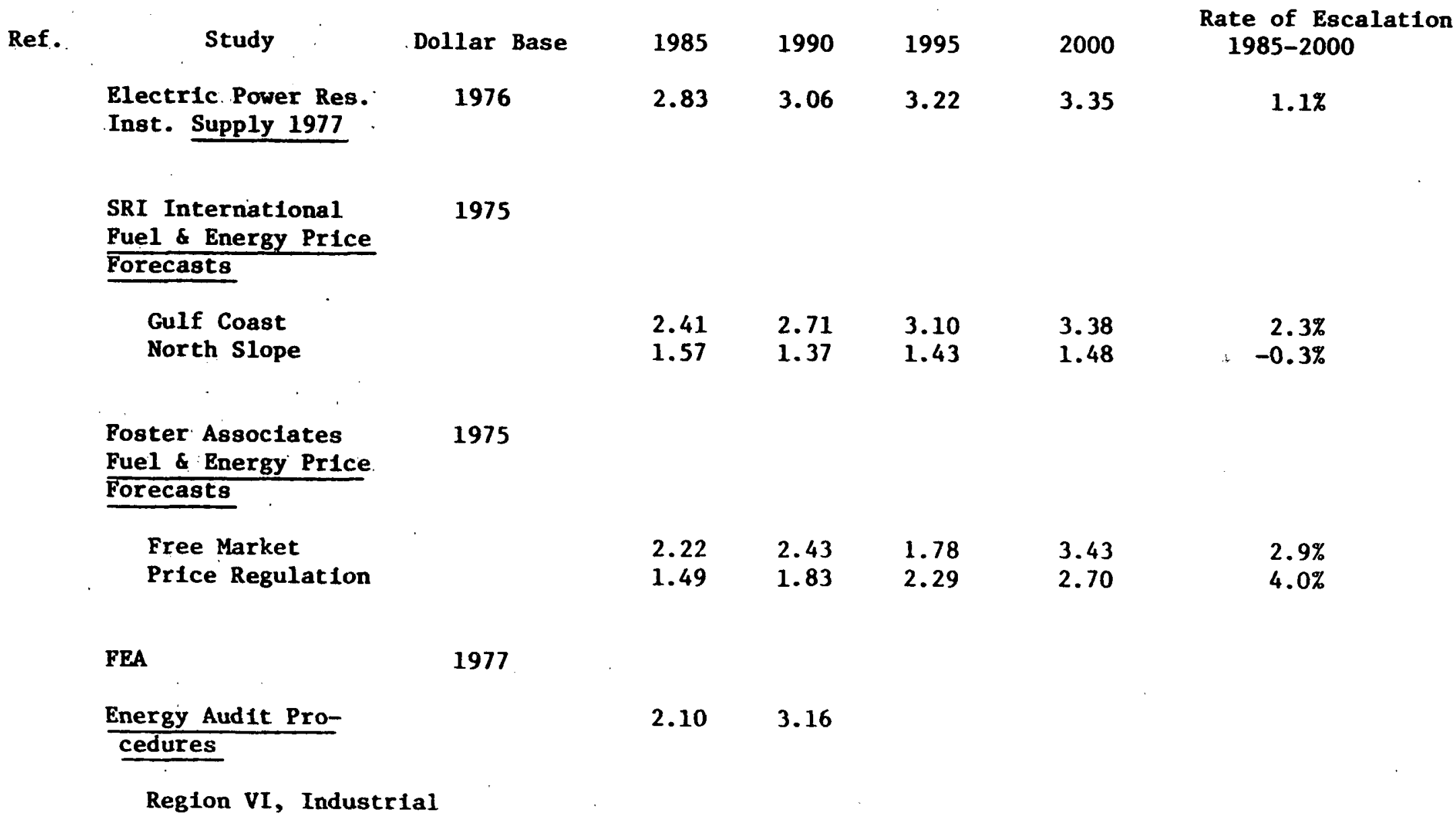


capital intensive, to assume a low cost of capital will reduce the cost of the hydrogen produced.

However, the comparison between utility financing and private industry financing is more than a question of how to calculate the cost of capital. It has broader implications about the manner in which hydrogen production technologies might be brought into use. The next section addresses the economics of hydrogen from coal from plants owned by private companies, while the following section considers questions of hydrogen production facilities owned by public utilities.

b. Hydrogen Production Through Private Industry. The study providing the most detail on which to base an evaluation of market potential of hydrogen produced through coal gasification is the one by Exxon Research and Engineering with the accompanying documentation by Chem Systems. The Exxon study concludes that producing ammonia and methanol through coal gasification will become competitive with producing from natural gas in the $1980^{\prime} \mathrm{s}$, assuming that a coal gasification technology improved over that typified by Koppers-Totzek becomes available. Since this indicates relatively early market penetration by coal gasification technologies even without government incentives, it is appropriate to examine more closely the basis of these conclusions.

Figure III- 3 shows the comparative costs of producing hydrogen through current Koppers-Totzek coal gasification and through conventional steam reforming of natural gas for various scales of plant and for different prices of natural gas and coal. The costs shown were calculated using the same assumptions and procedures as in the study for Exxon. It is clear that hydrogen produced through existing coal gasification technology costs significantly more than hydrogen produced from natural gas.

Figure III-3 shows what would be required for hydrogen produced through coal gasification to become competitive with hydrogen produced through steam reforming of natural gas. Improved coal gasification technology would provide some economies. Thus, for a plant capacity of 100 million standard cubic feet ( $S C F$ ) per day, hydrogen can be produced from natural gas at $\$ 2.00$ per thousand SCF, through Koppers-Totzek coal gasification at $\$ 3.11$ per thousand $S C F$, and through "new" gasification at $\$ 2.60$ per thousand SCF. Rising costs of natural gas will also narrow the gap.

The Exxon study assumed natural gas priced at $\$ 3.15$ (1980 \$) in 1980 , a real price escalation of 1.5 percent for natural gas, and no rise in the price of coal. On 


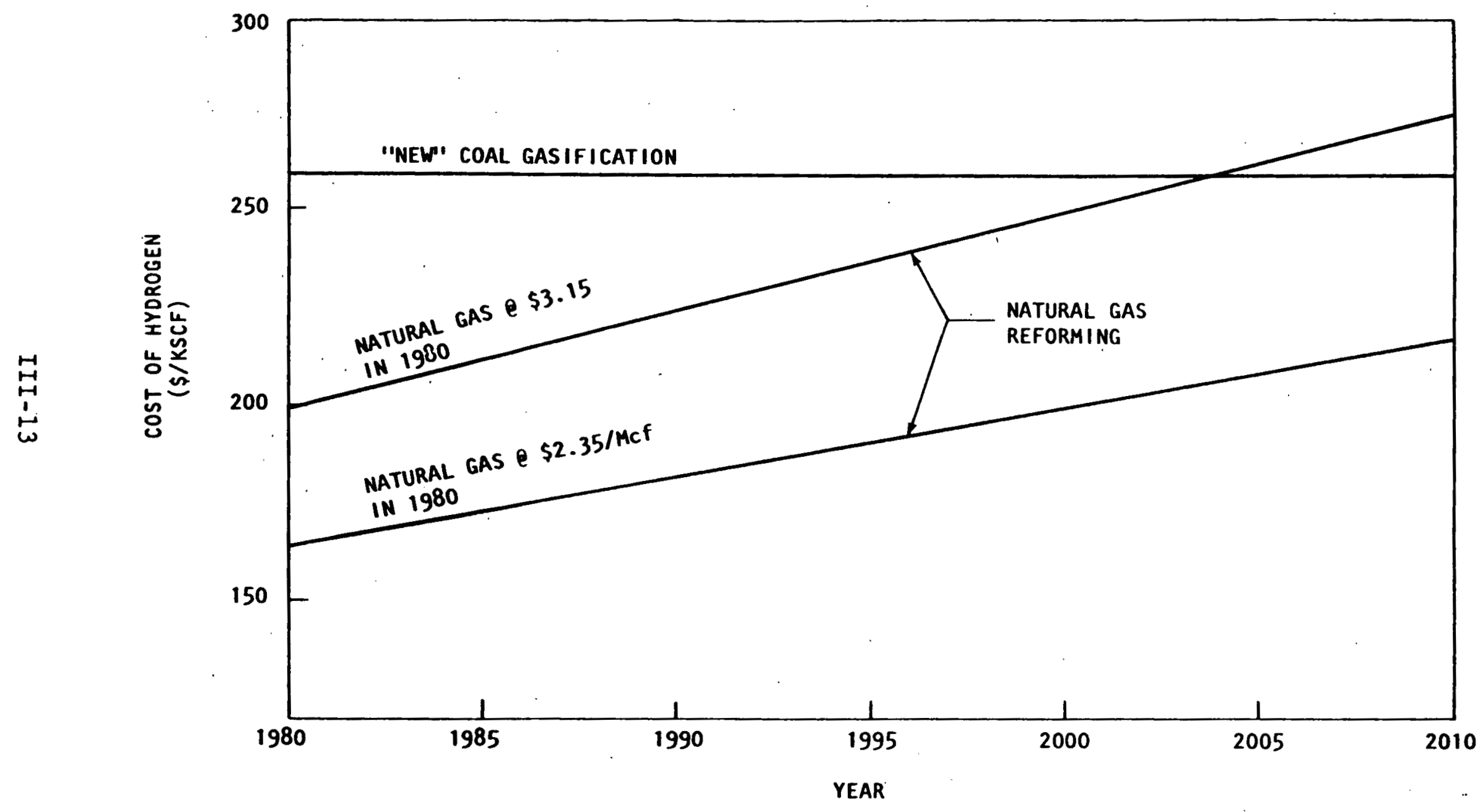

Figure III-3. Hydrogen Production Costs Natural Gas Reforming vs. "New" Coal Gasification 100 Million SCF/Day Plant, 1980 \$ 
these assumptions, the cost of producing hydrogen from natural gas would not rise to that of producing hydrogen through new coal gasification until 2003, as Figure III-3 illustrates. The sensitivity of hydrogen production costs to different assumptions about prices of natural gas and of coal is illustrated in Figure III-4. The different assumptions about prices are based on examination of other projections for prices of natural gas and of coal.

Natural gas prices will be determined between now and 1985 by the natural gas pricing bill currently before Congress. This bill would establish a price ceiling of $\$ 1.75$ per million cubic feet for interstate and intrastate gas beginning April 20, 1977. The price would be allowed to escalate at an annual rate of 3.5 percent plus the consumer price index, through April 20, 1981. After that, the escalation rate would be 4 percent plus the consumer price index. Assuming a rate of general inflation of 5 to 7 percent from 1977 to 1980 , the price of natural gas under this bill's provisions would therefore be $\$ 2.24$ to $\$ 2.36$ per million cubic feet (1980 \$) in 1980 .

Projections of natural gas prices from other studies are summarized in Table III -3 . The prices shown are for the price of natural gas near the point of production. Except for the price regulation scenario of Foster Associates, the various projections show a fair degree of consistency. Putting aside the increases in the consumer price index, the provisions of the natural gas pricing bill imply a price of natural gas in 1985 of $\$ 2.35$ per million cubic feet (1977 $\$$ ). The studies in Table III-3 show prices in 1985 falling in this range. Growth rates projected for 1985 to 2000 range from 1.1 percent to 2.9 percent, bracketing the assumption of 1.5 percent in the Exxon study. The price regulation scenario of Foster Associates shows a relatively high real rate of price escalation of around 4 percent, but the prices of natural gas assumed in that scenario are significantly lower than in the other projections.

Prices projected in various studies for coal delivered to a mid-continent region are summarized in Table III -4 . The prices of $\$ 21.80$ per ton $(1980 \$)$, or about $\$ 17.80$ per ton in $1977 \$$ assumed in the Exxon study, appear to fall at the low end of the estimates. The assumption of no escalation in the price of coal made in the Exxon study, however, is consistent with the scenarios shown by EPRI and by SRI. Sherman Clark and Foster Associates show the price of coal rising between 1985 and 2000 , at about 2.5 percent and about 1.9 percent, respectively. 


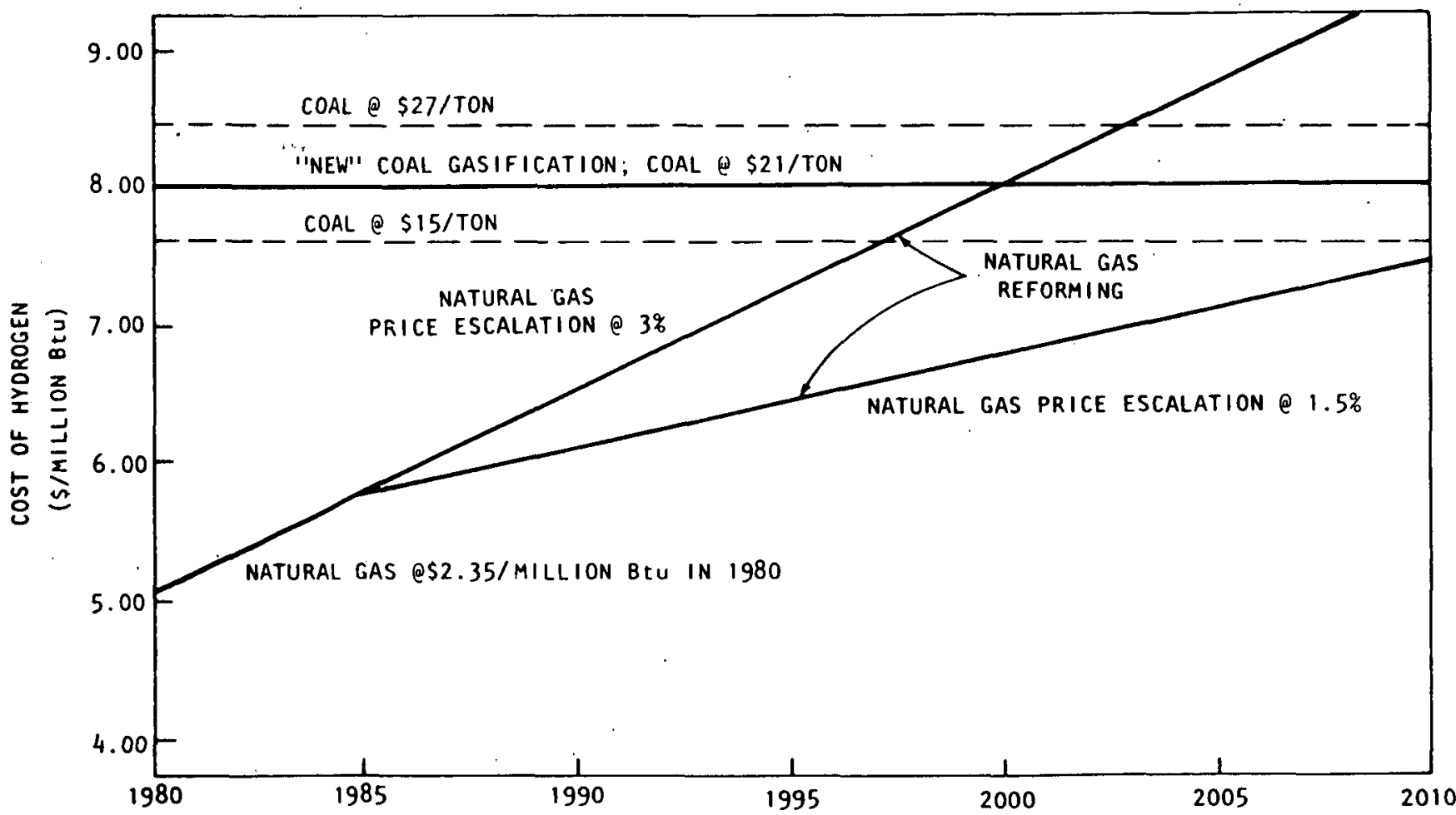

Figure III-4. Hydrogen Production Costs Natural Gas Reforming vs. "New" Gasification

100 Million SCF/Day Plant, 1980 \$ 
TABLE III-4. PROJECTIONS OF COAL PRICES

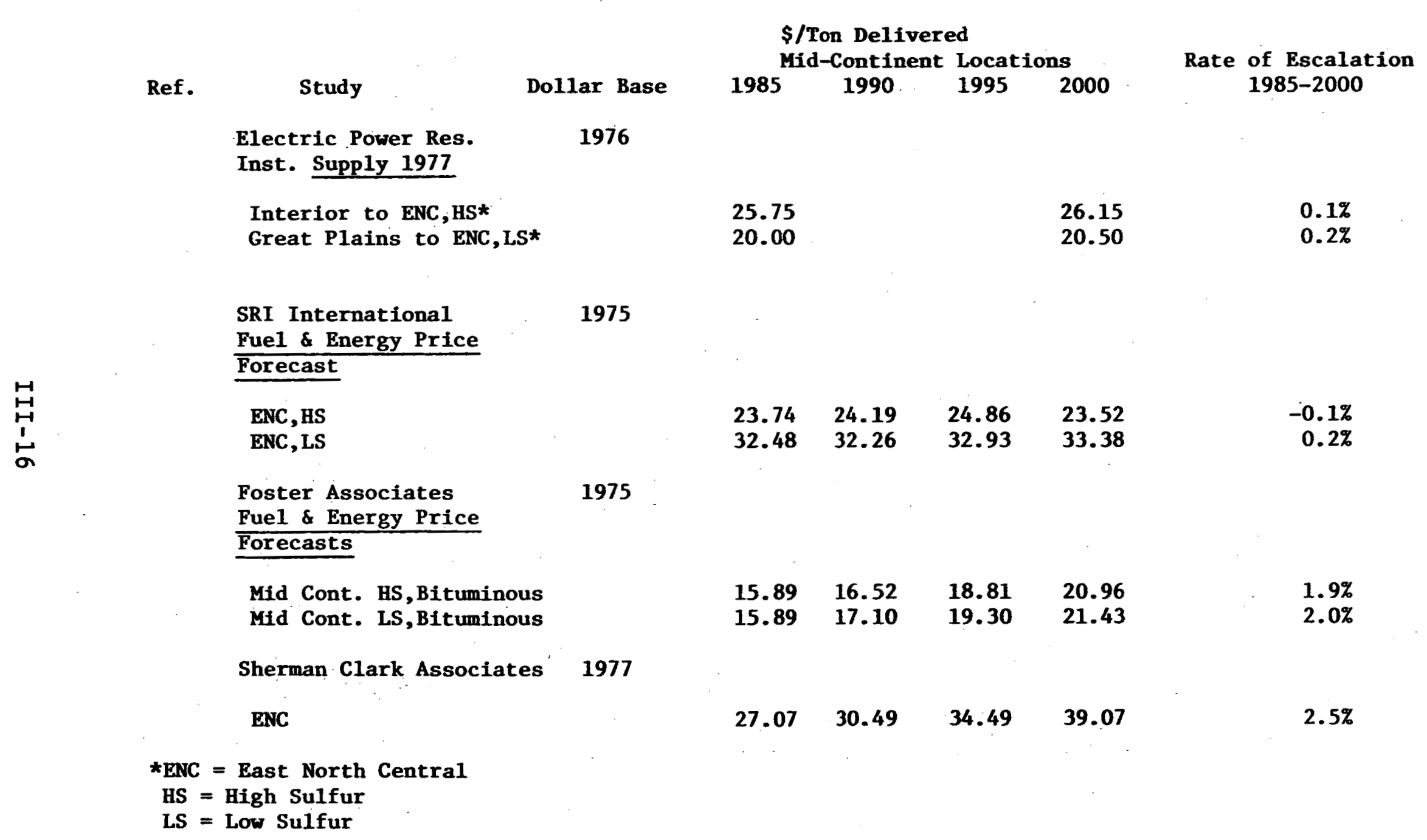


These projections for prices of natural gas and for coal suggest that the ratio of the price of natural gas to the price of coal used in the Exxon study is too high. There is reason to argue, for example, that a price of $\$ 3.15$ for natural gas in 1980 is too high. Should the natural gas pricing bill become law, the price of natural gas in 1980 will be around $\$ 2.35$ per million cubic feet $(1980 \$)$. Using a price of $\$ 2.35$ rather than $\$ 3.15$ can significantly change the conclusions about the time when production of hydrogen from coal can become economically competitive with production from natural gas, as Figure III-3 illustrates.

In considering the use of hydrogen in ammonia production, it was concluded in the Exxon study that production of ammonia through coal gasification will become economically competitive with steam reforming of natural gas by 1989. This conclusion, however, depends fundamentally on the size assumed for the production facility and on the assumed increases in prices of natural gas and coal.

The basis used in the Exxon study for comparing the costs of producing only hydrogen from coal and from natural gas was a plant producing 100 million SCF of hydrogen per day. In evaluating the production of ammonia, however, the basis for comparison was a plant producing 2000 tons of ammonia per day. On the assumption that producing a ton of ammonia requires between 70 and 80 thousand cubic feet of hydrogen, a plant producing 2000 tons per day would require from 140 to 160 million SCF of hydrogen per day. Thus, the basis for the comparison has shifted significantly. Previous work by Chem Systems has shown that the economics of producing ammonia from coal improve relative to the economics of production from steam reforming of natural gas when the scale of the plant is changed from 1000 tons per day to 2000 tons per day [Ref 7]. Thus, the improved competitive position implied for hydrogen from coal in ammonia production reflects in part the assumption about the scale of plant chosen. There is, however, some question as to the number of 2000 tons/day ammonia plants that will be built. As noted in Chapter II, current opinion indicates that the economics of ammonia production plants are such that plants in the range of 1000 to 1500 tons/day are probably optimal. Accordingly, costs of production for a 2000 ton/day plant would appear unrepresentative.

The timing for ammonia production from coal to become economically competitive with production from natural gas also depends on the prices assumed for natural gas and for coal in 1980 and on the rates of escalation of these prices beyond 1980. It is assumed in the Exxon study that the price of natural gas in 1980 will be $\$ 3.15$ ( $1980 \$)$, escalating at a real rate of 1.5 percent a year beyond 1980 . 
Coal delivered to a mid-continent location is assumed to cost $\$ 21.80$ per ton (1980\$), with no escalation in price in real terms beyond 1980 . In the Chem System calculations in the Exxon study, a coal price of $\$ 21.00$ per ton was used. The appropriateness of these assumptions is called into question by the other projections for prices of natural gas and of coal which were examined.

In particular, with natural gas priced at $\$ 3.15$ per million cubic feet, natural gas costs account for $\$ 110$ of a total cost of $\$ 209$ per ton of ammonia in 1980 . With natural gas priced at $\$ 2.35$ per million cubic feet, the total cost is $\$ 181$ per ton, of which natural gas accounts for $\$ 82$. Assuming that the price of natural gas rises at a real rate of 1.5 percent a year after 1980 , Figure III-5 shows that the cost of producing ammonia from natural gas would equal the cost of producing ammonia from coal by 1989 when natural gas is priced at $\$ 3.15$ per million cubic feet, but not until 2100 for natural gas priced at $\$ 2.35$ per million cubic feet. These dates would recede even further if the scale of the plant considered were in the range of 1000 to 1500 tons per day.

A recent comparison of the costs of producing ammonia from different feedstocks, prepared by engineers at the Tennessee Valley Authority, also suggests that the assumed prices for natural gas and for coal in the Exxon study are biased in favor of the economics of coal gasification. The TVA study compared technologies for ammonia production assuming natural gas priced at $\$ 2.00$ per million cubic feet and coal priced at $\$ 22.75$ per short ton. Taking these estimates and assuming a real rate of escalation of 1.5 percent for natural gas prices and no escalation for coal prices, production of ammonia from coal becomes competitive with production from natural gas around the year 2000 .

Thus, the conclusion in the Exxon study that ammonia from coal can become competitive with ammonia from natural gas by the end of the $1980^{\prime} \mathrm{s}$ appears optimistic. The plant scale of 2000 tons per day used to derive the cost comparisons appears unrepresentative, since that scale is larger than most existing or projected plants. Moreover, the price assumed for natural gas appears to be too high relative to the price assumed for coal.

A similar line of reasoning applies to the conclusion that the cost of producing methanol from coal will become competitive with the cost of producing methanol from natural gas in the early 1980's. Figure III-6 shows that assuming a price of $\$ 2.35$ per million cubic feet for natural 


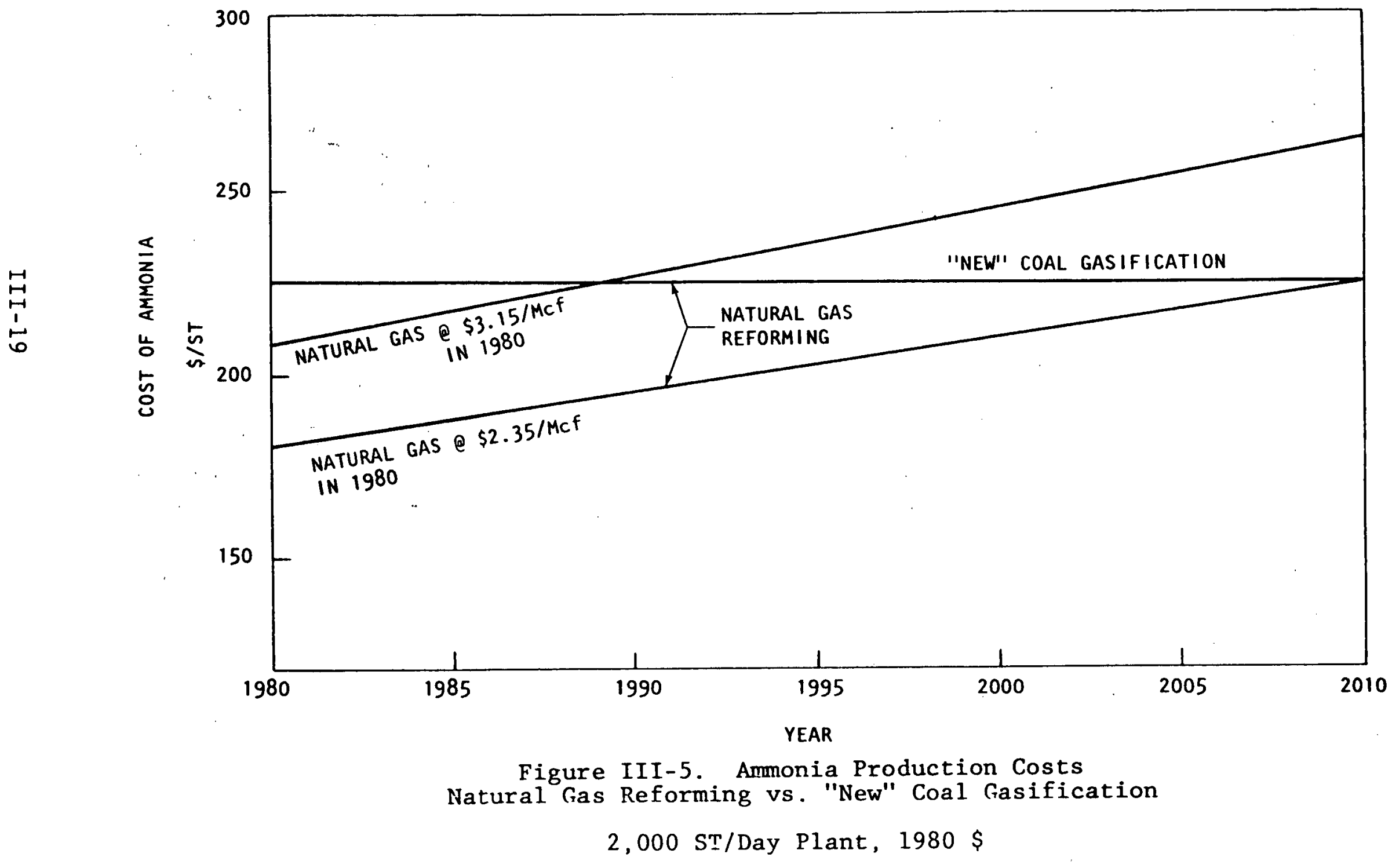




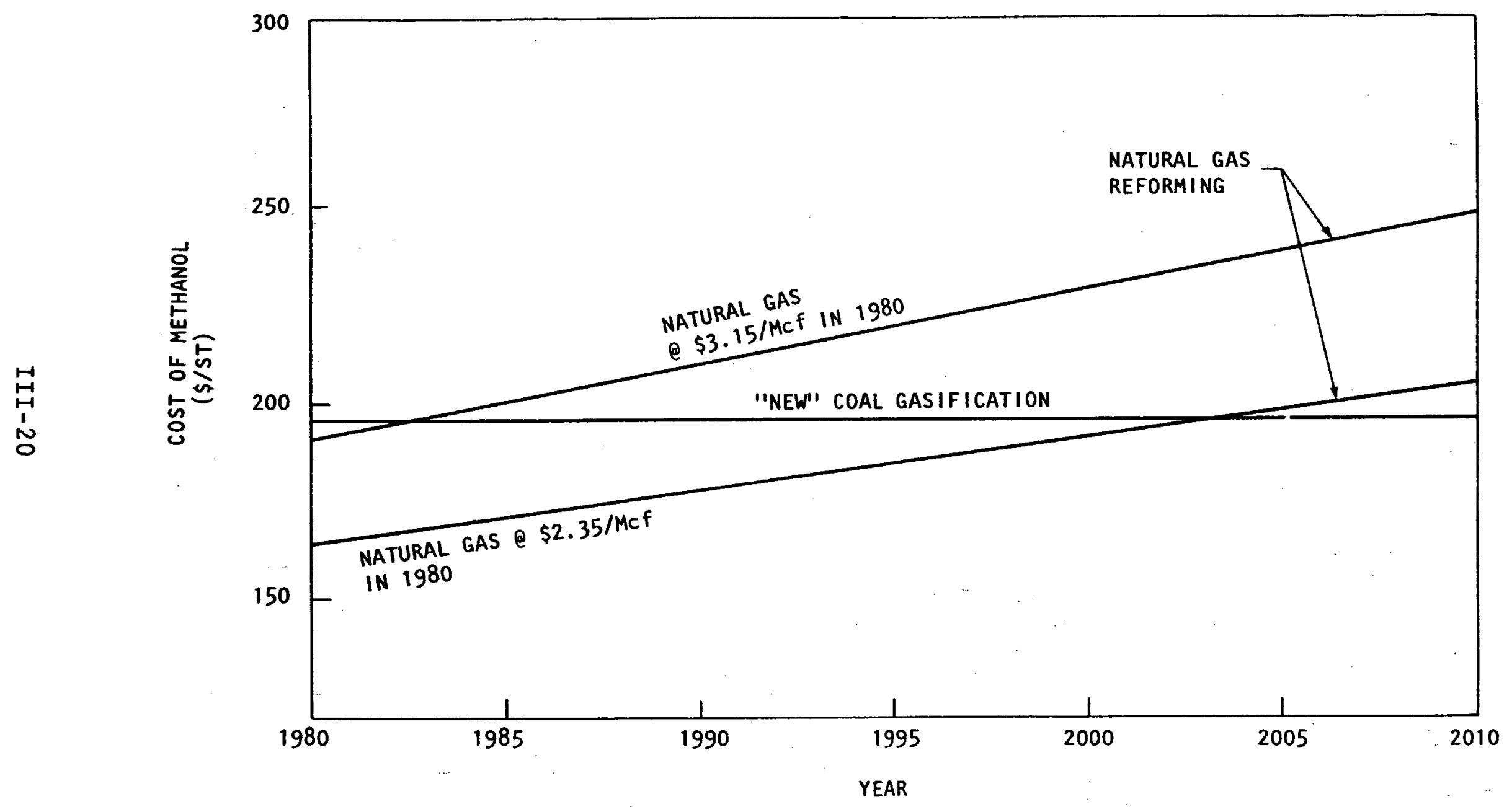

Figure III-6. Methanol Production Costs

Natural Gas Reforming vs. "New" Coal Gasification

2,000 ST/Day Plant, $1980 \$$ 
gas in 1980 would imply that the costs of producing methanol from natural gas do not reach the costs of production from coal until the year 2003.

The discussion in this section therefore indicates that probabilities appear to be low for hydrogen production through coal gasification to come into use in this century under the auspices of industrial firms without other incentives.

c. Ut1lity Ownership of Hydrogen Production Fac1l1ties. The capital costs of producing hydrogen through coal gasification seriously impact the economic competitiveness of such technologies. A lowering of a faclifty's capital costs could Improve its competitiveness significantly. This point is 1llustrated in Figure III-7, which points out the differences in the cost of hydrogen produced through Koppers-Totzek gasification under private financing and under utility financing [Ref. 2]. On the assumption of utility financing for the coal gasification fac1lity, hydrogen from coal becomes competitive with hydrogen produced from natural gas under private industry (Flgure III-7).

A cruclal difference between utility financing and private Industry financing is the calculation of the cost of capital. This funding may be obtained elther through debt financing, through equfty financing (such as the 1sauing of stock), or more generally, a combination of the two. The cost of obtaining capital is given by the weighted average:

$$
\text { Cost of capital }=(d) 1+(1-d) r
$$

where

d is the percentage of the financing which is debt

1 is the interest rate paid on debt

$r$ is the rate of return on equity.

In general, the interest rate on debt is lower than the rate of return on equity.

Historically, the public utility industry in the U.S. has been relatively stable, and this stability enabled utilities to obtain financing at a relatively low cost of capital. The interest rate a firm pays on 1 ts debt, as well as the rate of return on its equity, depends on the business and financlal risk of that firm. When utilities operated in a non-inflationary, favorable regulatory climate, their 


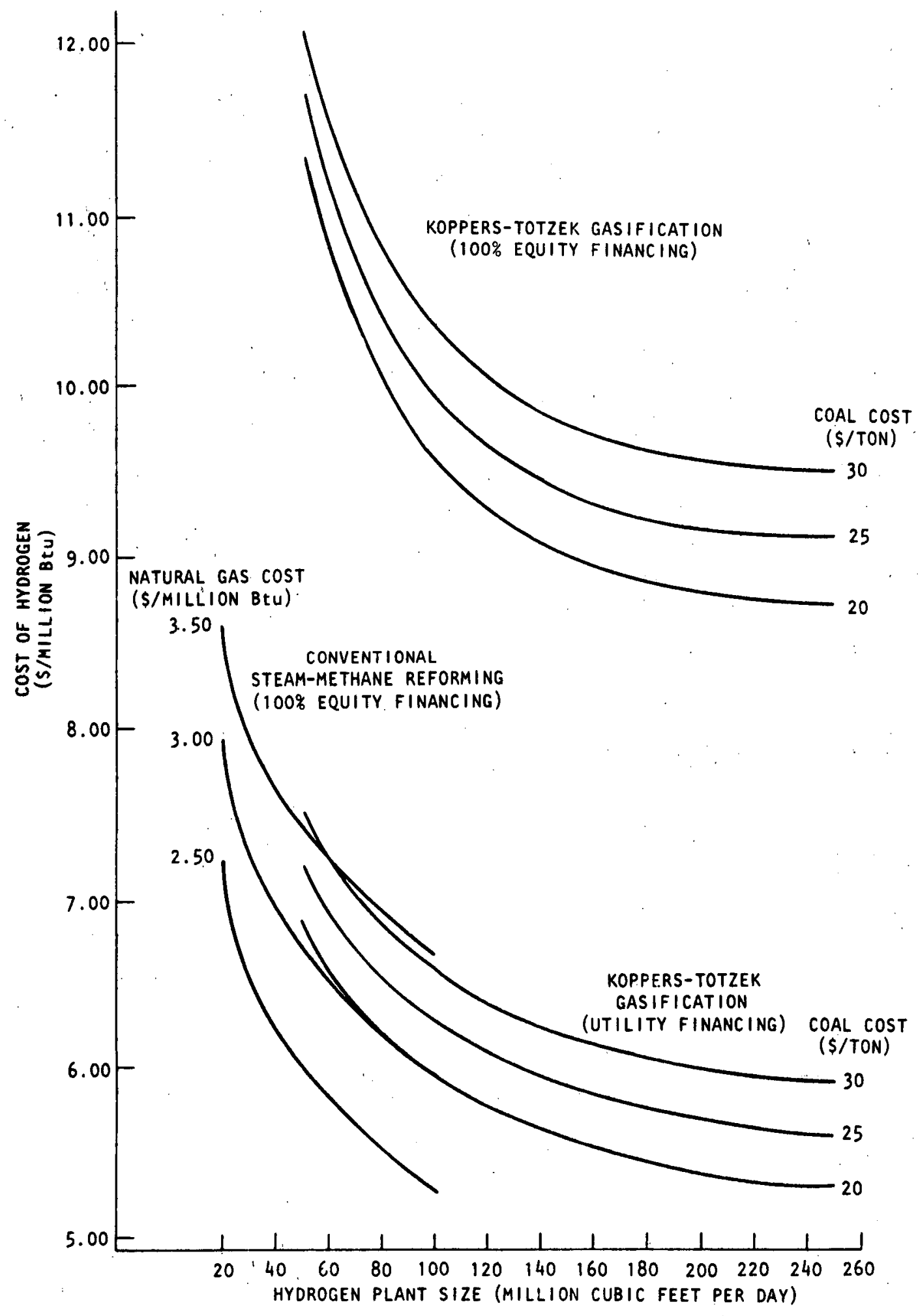

Figure III-7. Comparative Costs of Hydrogen Through Coal Gasification Equity vs. Utility Financing, 1980 \$ 
business and financial risk was generally lower than for industrial firms. This lower degree of risk was reflected in interest rates on debt and rates of return on equity which were lower than for industrial firms. Moreover, the stability of the utilities meant less financial risk for any given percentage of debt, enabling them to carry a higher percentage of debt than was possible for most industrial firms. Thus, lower rates on debt and equity and a higher debt-to-equity ratio contributed to making the cost of capital lower to utilities than to industrial firms.

In recent years, however, the business and financial risks of utilities, particularly electric utilities, have increased significantly. Thus, assumptions about interest rates on debt, about rates of return to equity and about debt/equity ratios which applied in the past to utilities, may no longer hold. However, one's impression is that calculations using the utility financing approach often apply assumptions based on historial circumstances which are no longer relevant. The utility financing approach ought not to be a mechanical application of a formula; rather, serious questions should be raised as to whether the interest rates, debt-to-equity ratio, depreciation assumptions, etc. being used are indeed representative of the situation.

In particular, although Figure III-7 suggests that utility financing would lower the cost of producing hydrogen from coal, two important questions need to be answered. First, what incentives are there for a utility (in this case, probably a gas utility) to invest in a facility for producing hydrogen from coal? Second, even if the utility were interested, would the financing be available on the same terms which applied to other business lines of the utility? The recent experiences of gas utilities in obtaining financing for syngas projects suggest the difficulties likely to arise for any utility venturing on an investment in comparatively untried technology for producing hydrogen from coal. While these appear to be questions that should be answered, their exploration is left for other studies.

\section{Electrolytic Production of Hydrogen}

A survey and evaluation of the costs of producing hydrogen through electrolysis was also undertaken. The technologies for electrolysis are briefly described in the first section below, followed by an evaluation of costs presented in various studies. 


\section{Technological Options}

In production of hydrogen through electrolysis, direct electric current is fed to an electrochemical cell, and hydrogen and oxygen are produced through the dissociation of water. The main components of the electrochemical cell are the electrodes (anode and cathode), the electrolyte, and the diaphragm.

- The electrodes used must be corrosion resistant in the electrolytes, must be good electronic conductors, must catalyze the evaluation of hydrogen (cathode) and of oxygen (anode), and must have structural integrity.

- The electrolyte used must be such that only the water dissociation reaction can take place. Current electrolysis technologies use an aqueous potassium hydroxide solution as the electrolyte.

- The diaphragm separates the hydrogen and the oxygen produced and prevents the formation of an explosive gas. Current electrolysis technologies generally use a liquid-permeable, but gas-impermeable membrane of asbestos fibers to divide the anode compartment of the cell from the cathode compartment.

The technical characteristics of an electrolytic cell which are of particular importance in the economics of hydrogen production are the cell current density and the cell volt age.

The cell current density determines the rate of hydrogen production per unit of cell area and is a primary factor determining the capital cost of an electrolytic cell. In particular, the capital cost of an electrolytic cell per kilowatt of hydrogen produced is directly proportional to the capital cost per unit of cell area and inversely proportional to the current density. The capital cost per unit of cell area depends in turn on the type of construction and on the materials used. In general, cells using low-cost materials operate at low current densities, while use of higher cost materials permits the use of higher current densities.

Cell voltage determines the efficiency of water electrolysis and is therefore the primary factor in determining the operating costs of an electrolytic cell. Cell voltage can be represented by: 
$V=E+n c+n a+i R$

where

$\mathrm{V}$ is the cell operating voltage

$E$ is the voltage theoretically required for dissociation

nc is the cathode overvoltage (which depends on the material)

na is the anode overvoltage (also depending on the material)

$i$ is the cell current

$R$ is the cell resistance.

Efforts to improve electrolytic technology are directed toward minimizing $n c$, na and $i R$, thereby reducing cell voltage and improving efficiency. Three different methods of improving electrolytic technology are being pursued.

In one method, essentially an extension of current technology, an aqueous alkaline solution of high concentration is electrolyzed at temperatures up to $160^{\circ} \mathrm{C}$. (Current state-of-the-art technologies use temperatures of 60 to $80^{\circ} \mathrm{C}$ ). The higher temperature reduces cell voltage, with the electrolysis taking place under high pressure to prevent boiling and unacceptable water losses due to evaporation.

In a second method, steam is electrolyzed at temperatures of 600 to $1000^{\circ} \mathrm{C}$. A zirconium oxide ceramic is used as the electrolyte, conducting oxygen ions and acting as membrane and electrolyte at the same time. No overvoltages occur at the high temperatures used with this technique, and ohmic losses (i.e., iR) are small. However, at an operating temperature about $800^{\circ} \mathrm{C}$, a mixture of.hydrogen and steam is always produced, which can be separated at present only with difficulty through cooling and condensing. Moreover, material problems are significant at the high temperatures used in this method.

The third method, electrolysis with a solid polymer electrolyte being developed by General Electric, is distinctive in that an ion-exchange membrane instead of an alkaline solution is used as the electrolyte. Because the membrane can be kept very thin (e.g., $0.1 \mathrm{~mm})$, the ohmic losses can be greatly reduced. SPE electrolysis is best performed at temperatures of 120 to $150^{\circ} \mathrm{C}$ and pressures over 200 bar. The main technical problem is the chemical durability of the anode material, which comes in contact with 
the acid membrane and is consequently exposed to severe corrosive effects.

2. Cost of Hydrogen through Electrolysis

Table III-5 summarizes the estimates made in various studies of the cost of producing hydrogen through electrolysis and also the assumptions on which the estimates are based. The cost of producing hydrogen through the electrolysis of water can be broken down into three elements:

- The cost of electric energy.

- Capital Costs - equipment, installation, cost of financing.

- Operating and maintenance costs.

The general consensus of the studies is that operating and maintenance costs are a minor element, amounting to about 5-7 percent of the capital costs per year. This section analyzes and evaluates the estimates of hydrogen production costs presented in the various studies surveyed.

a. Production Economics for Hydrogen, Ammonia and Methanol During the 1980-2000 Perlod. In this study, Exxon presented cost estimates for current and projected large-scale and small-scale electrolyzers.

The projections for current electrolyzer technology were presented without explanation in the Exxon study. No breakdown of the cost elements in the capital costs of the electrolysis unit were provided except that $\$ 650 / \mathrm{KW}$ was for "onsites" and $\$ 100 / \mathrm{KW}$ was for "offsites." In a telephone conversation; Hampton Corneli reported that these costs probably represented a conventional or current technology established to operate at a hydrogen pressure of 450 psig in 1980.

The projections for future electrolysis costs were prepared by Chem Systems, Inc. for Exxon from data obtained from General Electric on projected costs in 1980 of G.E's solid polymer electrolytic cell. The plant was priced for a location in the U.S. Gulf Coast, to be completed in the mid 1980's. The cost estimates include 30 percent of total investment as a contingency factor.

Finally, Exxon generated some costs for the production of hydrogen with small-scale electrolyzers in the year 1980, using the projected General Electric Solid Polymer Electrolytic technology and $27 \mathrm{mills} / \mathrm{KWh}$ as a cost for 
TABLE III-5. ESTIMATES OF COST OF PRODUCING HYDROGEN THROUGH ELECTROLYSIS

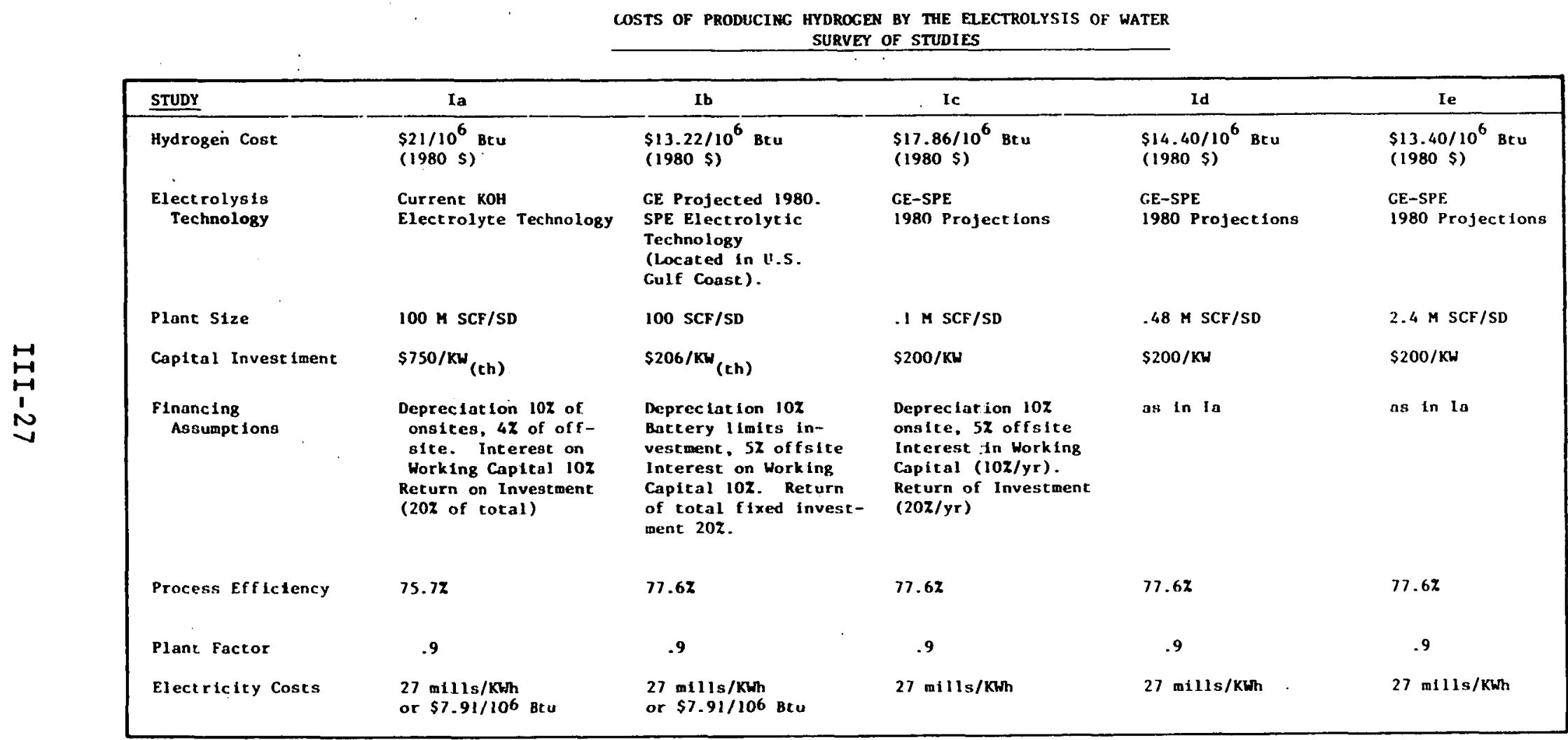

Studies:

I. Corneil, H.G.; Heinzelmann, F.I. Nicholson, H.S., Production Economics For Hydrogen, Ammonia and Methanol During The $1980-2000$ Period Exxon Research and Engineering Company, April 1977 for Brookhaven Nat ional Laboratory. 


\section{TABLE III-5 (Continued)}

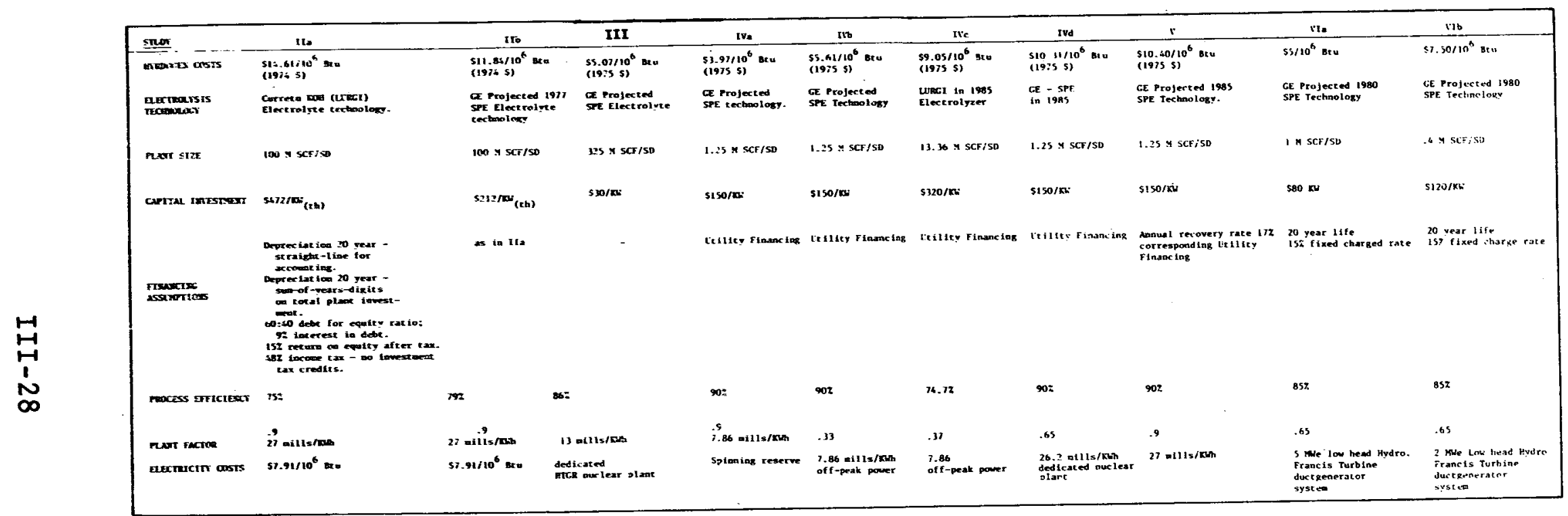

stedie

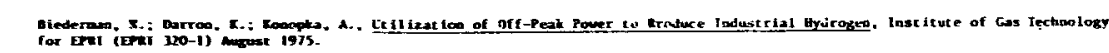

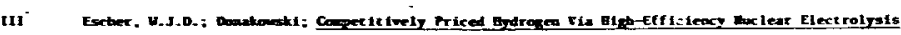

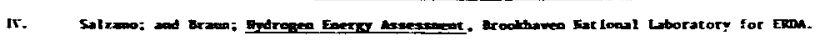

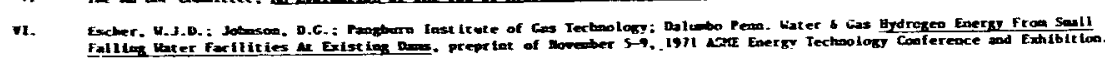


industrial electricity. The GE electrolysis technology was priced out at $\$ 200 / \mathrm{kw}$ for each of three plant sizes: 0.1 $\mathrm{MSCF} / \mathrm{SD}, .48 \mathrm{MSCF} / \mathrm{SD}$ and $2.4 \mathrm{MSCF} / \mathrm{SD}$. A process efficiency of 77.6 percent was assumed to have been attained at these capital costs in 1980 .

\section{Study Projection Ia}

In this projection Exxon generated a cost of $\$ 21$ (1980 \$) per million Btu of hydrogen produced. This is based on a capital cost of $\$ 750 / \mathrm{KW}$, a process efficiency of $75.7 \%$ and 1980 operation using electricity costing $27 \mathrm{mills} / \mathrm{KWH}$. The energy cost is significant, amounting to $\$ 10.45$ for each million Btu of hydrogen produced or about $50 \%$ of the total cost. The capital costs seem reasonable for the operation of one of the currently available KOH electrolyte technologies.

In a telephone conversation, Hampton Corneil, one of the co-authors of this study, stated that this work-up was done to provide a common working pressure so that an equivalent amount of hydrogen at a given pressure could be priced and compared with the cost of hydrogen from the natural gas reforming process and the coal gasification process. The common pressure chosen was 450 psig. Currently available Lurgi electrolyzers produce hydrogen at a pressure of $425 \mathrm{psig}$. Vendor quotes from Lurgi were obtained by the Institute of Gas Technology in 1974 showing equipment costs of about $\$ 310$ per kilowatt thermal [Ref. 3]. Escalating these equipment costs to 1980 using an annual rate of $8.7 \%$ ( $7 \%$ inflation $+1.7 \%$ historical gap for capital equipment as estimated by Chem Systems [Ref. 1] results in equipment costs of $\$ 510$ per kilowatt thermal. Assuming installation costs are $50 \%$ of the equipment costs, this gives installed capital costs of $\$ 765$ per kilowatt thermal output. If the capital costs actually charged by Lurgi follow these assumptions, $\$ 21$ per million Btu of hydrogen produced at 450 psig appears to be a reasonable estimate for the cost of production in the year 1980 if $27 \mathrm{mill} / \mathrm{KWh}$ electricity is available.

\section{Study Projection Ib}

This projection is based on a conceptual study of the cost of producing hydrogen by the electrolysis of water in the year 1980 using the General Electric projected solid polymer electrolyte technology available in that year. The estimates were prepared by Chem Systems, Inc. for Exxon for a $100 \mathrm{MSCF} / \mathrm{SD}$ sized plant located in the U.S. Gulf Coast area with electricity available at $27 \mathrm{mills} / \mathrm{KWh}$. The energy cost component amounts to $\$ 10.19$ per milition Btu of hydrogen produced, approximately $77 \%$ of the total cost. 
Comparing the hydrogen produced by this

method to the cost of $\$ 21$ per million Btu generated by the previous Ia work-up shows the significant effect of the 73 percent reduction in capital costs. The efficiencies of the two systems are essentially the same. Also the method of financing was the same in both work-ups. With a capital cost of only $\$ 206$ per kilowatt thermal output, the G.E. system produces hydrogen at 63 percent of the cost required by the conventional system.

It should be noted here that the capital costs for the G.E. system are projections of R\&D goals. G.E. has no medium or large scale SPE System commercially available. In a recent paper [Ref. 4] G.E. presented its program goals which are summarized below:

Program Goals GE-SPE Development Programs

(2) $90 \%$ efficiency

INSTALLED ELECTROLYSIS SYSTEM

- Electrolysis Module

- Power Conditioner

- Ancillary Components

- Installation
$\$ 82 /$ KWe (1975\$)

$\$ 13 / \mathrm{KWe}$

$\$ 139 /$ KWe

$\$ 15 / \mathrm{KWe}$

$\$ 8 / \mathrm{KWe}$

The key effort is on the reduction of the electrolysis module costs. In 1975 the production costs of the electrolysis module were $\$ 188 / \mathrm{KWe}$; by 1977 the costs had been reduced to $\$ 64 / \mathrm{KWe}$. With adequate funding G.E. predicted in 1977 that they could achieve the electrolysis module goal of $\$ 73 /$ KWe by 1983 and demonstrated it in a 5 MWe (1.13 MSCF/SD) sized plant [Ref. 4]. With reduced funding they drop back their estimate to 1985 .

Based on his evaluation of G.E.'s research program A.P. Fickett, Program Manager at EPRI for Fuel Cells and Chemical Energy Conversion, is of the opinion that G.E. is likely to have a large scale commercial SPE electrolysis system available at $\$ 150 / \mathrm{KW}$ in the late $1980^{\prime} \mathrm{s}$ or early $1990^{\prime} \mathrm{s}$ with adequate funding. In light of this informed opinion and the fact that G.E. itself is only proposing to construct a $1.13 \mathrm{MSCF} / \mathrm{SD}$ demonstration facility by 1983 at the earliest, projections for a $100 \mathrm{MSCF} / \mathrm{SD}$ sized plant in 1980 must be viewed with some skepticism. 
b. Utilization of off Peak Power to Produce Indus trial Hydrogen. This study by the Institute of

Gas Technology for EPRI is almost a handbook for a utility considering the production of hydrogen. They solicited information from three major vendors of electrolysis devices General Electric, Teledyne and Lurgi Apparate-Technik. This data included technical and economic data on capital costs, operating parameters, scale up factors and polarization curves. The equipment costs are quoted from the vendor in 1974 on the actual price of their equipment. Since the G.E. system is not scheduled to be put on the commercial market until 1980, the G.E. figures represent future costs in 1974 .

The total plant cost was generated using a factor of 1.5 on the capital costs from the vendor quotes. The price of the land and site preparation is left out. Annual operation and maintenance costs were in a range of 5-7 percent of equipment costs. No price of electricity is assumed. The cost of hydrogen is generated parametrically over a wide range of electricity prices and plant factors.

\section{Study Projection IIa}

In this projection (performed in 1974) IGT solicited vendor quotes from the manufacturers. Scaling these quotes up by $50 \%$ to include the cost of installation, the resulting capital costs are $\$ 472$ per kilowatt thermal output.

Note that there is no general agreement among the studies on the factor to use for installation costs. IGT in this study uses $50 \%$ or $\$ 150 / \mathrm{KWth}$. A.P. Fickett in a study [Ref. 5] gives installation costs as approximately $\$ 50$ per kilowatt thermal of hydrogen produced and adds that this will vary with site; building codes, and local labor rates. The IGT figure of $50 \%$ is based on utility experience with fuel cell installation and input from the manufacturers. The discrepancy is hard to reconcile and points out a major problem with all the estimates for hydrogen electrolysis production economics - - the lack of hands-on experience in the construction of large-scale electrolyzers in the United States.

Assuming electricity is available at 27 mills/KWh, electricity costs amount to $\$ 10.54$ in this estimate, or approximately 72 percent of the total cost of the hydrogen produced.

\section{Study Projection IIb}

This estimate was based on capital cost projections supplied to IGT by the General Electric Company in 1974 for their projected 1977 technology. Currently, G.E. 
is hoping to market 80 percent efficient units in the 100-500 KW range by 1981 and 90 percent efficient units in the $5 \mathrm{MW}$ range after 1983 [Ref. 6]. The marketing of the large scale unit depends (at GE's own admission) on the level of funding available from DOE and other sources.

Keeping in mind that these figures represent a not-yet-commercialized technology, we can comment on the significant reduction in capital costs. Using the 50 percent figure for installation costs, IGT works up a capital investment cost of $\$ 212$ per $\mathrm{KW}$ of hydrogen output. Using a cost of electricity of $27 \mathrm{mills} / \mathrm{KWh}$, the energy cost of producing the hydrogen is $\$ 10.00$ per million Btu of hydrogen produced - 85 percent of the total $\$ 11.84$ per million Btu derived.

According to the Edison Electric Institute [Ref. 7] the average revenue per unit of electric energy sold to large commercial and industrial users by U.S. electric utilities in 1976 was $20.7 \mathrm{mills} / \mathrm{KWh}$. Using this rate and IGT's estimated costs for a $\$ 212 / \mathrm{KW}$ SPE System gives a hydrogen production cost of $\$ 9.23$ per million Btu of hydrogen output.

An interesting calculation performed by IGT shows the effects of capital costs when trying to use low cost "off-peak" electric energy. Assuming that off-peak electricity was available at $10 \mathrm{mills}$ per kilowatt hour for six hours a day, hydrogen can be produced with a $\$ 212 / \mathrm{KW}$ SPE System at $\$ 9.38$ per million Btu. This is slightly more than the cost estimated assuming a 90 percent load factor but with an electricity rate twice as high. The cost of amortizing the capital investment must be spread over fewer units of hydrogen produced.

c. Competitively Priced Hydrogen Via High Efficiency Nuclear Electrolysis. This paper, presented at the 1st World Hydrogen Energy Conference, represents the conclusion of a preliminary system engineering study of an advanced nuclear electrolytic hydrogen production facility. Its concept is of a large dedicated nuclear reactor (high temperature, gas cooled) operating 3 helium turbines and an ammonia turbine to provide mechanical power to operate acyclic cogenerators coupled to G.E. solid polymer electrolyte electrolysis units. No financing assumptions used for cost estimates are listed in this report. The capital investment shown in Table III-5 are of the GE-SPE unit only, without power conditioning units. The use of cyclic DC generation eliminates the need for power conditioning. Voltage regulation is achieved through regulation of field current on the generators. The prices of uranium used are not given. The overall efficiency is given as 43 percent for conversion from nuclear heat to hydrogen energy. The cost of electricity 
is really an intermediate step in this process and is not provided by the authors.

\section{Study Projection III}

This study is unique in that it involves a conceptual design of a total electrolysis system from primary energy source (nuclear fuel) to the product hydrogen. Optimum system performance is sought for each phase of the energy transformation. This nuclear facility dedicated to hydrogen production by water electrolysis integrates three major system elements.

- an HTGR (High Temperature Gas Reactor) operating a binary shaft power-extraction cycle at $980^{\circ} \mathrm{C}$ top temperature.

- direct d.c. electricity generation via acyclic generators.

- SPE high-current density, high-pressure electrolyzers.

Using as a criterion the technologies available for commercialization in 1985 and a system operation in the early 1990's, IGT adopted a HTGR design developed by General Atomic Company. Since a nuclear plant is a heat engine, it depends on high input temperature and a near-toambient rejection temperature for maximum efficiency. IGT adopted the General Atomic design as having these qualities.

Since the electrolyzer requires direct current electricity of closely regulated voltage, the use of conventional 60 cycle a.c. power was dropped in favor of direct d.c. generation. When a.c. power is used, capital costs for the power conditioning unit needed to rectify and regulate the a.c. power costs are in the neighborhood of $\$ 45 \mathrm{KWe}$ : By generating d.c. directly this considerable capital cost is eliminated. In response to an IGT request, G.E. has projected an acyclic generator design with a liquidmetal current collection system that when coupled to the HTGR results in d.c. power costs of approximately $13 \mathrm{mills} /$ KWh. Voltage regulation is achieved by means of yield current adjustment of the acyclic generators.

The low capital cost of the electrolyzer is obtained by using the optimistic projections for the 1985 time frame from a paper by [.J. Nuttall [Ref. 8] as shown below. 
1985 projected

Electrolysis Module

Power Conversion

Ancillary Equipment

Installation

$$
\begin{gathered}
\$ 8.15 / \mathrm{KW}_{\mathrm{th}} \\
\$ 42.76 / \mathrm{KW}_{\mathrm{th}} \\
\$ 18.08 / \mathrm{KW}_{\mathrm{th}} \\
\$ 8.26 / \mathrm{KW}_{\mathrm{th}} \\
\$ 77.25
\end{gathered}
$$

(at $\frac{1977 \text { obtained }}{\text { lower efficlency) }}$

$\$ 64 / \mathrm{KW}$

*No data on large scale system Installation is avallable.

Eliminating the power conditioning equipment and some of the installation cost results in an installed capital cost for the GE-SPE electrolyzer of about $\$ 30 / \mathrm{KW}_{\text {th }}$ This projection, as can be seen from the above cost break down, is based on reducing the production costs of the electrolysis module by a factor of eight. As previously discussed the G.E. profections appear highly optimistic.

Taking this into account along with the fact that all three system elements in this conceptual design are technologies not commercially avallable at this time, the production cost of hydrogen of $\$ 5.07$ per million Btu's represents a highly optimal case. Indeed, this estimate can be regarded as the lowest possible price of large scale hydrogen production by water electrolysis in the 1990's.

d. Hydrogen Energy Assessment. In projections IV, IVb, and IVd the capital cost, plant capacity, and conversion efficlency of the General Electric solid polymer electrolyte water electrolysis equipment are based on data provided by R. Fernando to the ad hoc committee on Hydrogen as a natural gas supplement (see below for deta1ls). In projection IVc the plant capacity, capital cost, and conversion efficiency of the Lurgi electrolyzer are obtalned from the IGT report; however, no installation charges are figured in. The annual fixed charges on capital are assumed at 17 percent of investment per year.

\section{Study Projections IV}

The capital costs of $\$ 320 / \mathrm{KW}$ for the Lurg1 electrolyzer were obtained from the IGT study. Since the figure of $\$ 320 / \mathrm{KW}$ given by IGT is for equipment costs only and no installation costs have been added in, the resulting hydrogen production costs are underestimated. 
The capital costs for the GE-SPE system are projections for 1985 technology taken from the ad hoc Committee Study $V$. This study is interesting in that it considers various electricity supply scenarios.

\section{Study Projection IVa}

This work-up yields a hydrogen cost of $\$ 3.97$ per million Btu using a GE-SPE system with installed costs of $\$ 150 / \mathrm{KW}$ and spinning reserve power costing $7.80 \mathrm{mills} /$ KWh. Spinning reserve is generating capacity which is held for emergency reserve; the capacity is connected to the system and available in the event of a contingency loss of a generating unit. Since spinning reserve is already built into the rate base, BNL has charged only the cost of the fuel needed and the operating and maintenance costs associated with the generator. For a base load nuclear unit this runs about $7.86 \mathrm{mills} / \mathrm{KWh}$ in $1975 \mathrm{~s}$.

In the Pennsylvania-Jersey-Maryland power. pool, according to the BNL study, $200 \mathrm{MW}$ of spinning reserve were available in 1976 on a 10 hour/day, 300 day/year basis out of a total capacity of $42,000 \mathrm{MW}$ in the pool. The power is available at between $10-14 \mathrm{mills} / \mathrm{KWh}$. However, if this power is available only 10 hours a day the plant factor drops down to .42 . To evaluate this resource a survey would have to be made on how much of this power is available on a round-the-clock basis so the maximum utilization could be obtained from the electrolyzer.

\section{Study Projection IVd}

This scenario has the projected GE-SPE system being powered from a dedicated nuclear plant in 1985 , producing power at $26.2 \mathrm{mills} / \mathrm{kWh}$. The costs for this dedicated plant were based on a report by ERDA's office of the Assistant Administrator for Planning, Analysis and Evaluation entitled "Working Paper Forecasts and Scenarios 19852000." The major assumptions of this report are summarized below:

- $\$ 585 / \mathrm{KW}(1974 \$)$ for the plant

- Nuclear Fuel \$.65/MBtu in 1985 in $1975 \$$ $\$ .77 / \mathrm{MBtu}$ in 2000 in 1975 \$

- O\&M Costs of $1.2 \mathrm{mills} / \mathrm{KWh}$ or $\$ .11 \mathrm{MBtu}$

- Thermal Efficiency $33 \%$ in 1985

$34 \%$ in 2000

- Base load annual average factor $65 \%$. 
This system yields (in 1975 \$) a production cost of electricity of $26.2 \mathrm{mills} / \mathrm{KWh}$ in 1985 and $27.1 \mathrm{mills} / \mathrm{KWh}$ in 2000. Estimated hydrogen production costs would be respectively $\$ 10.31$ per million $B t u$ and $\$ 10.44$ per million Btu. The production costs generated here would depend on the achievement of the electrolyzer development goals at General Electric and the non-escalation of nuclear capital costs (in constant year dollars).

\section{Study Projections IVb}

In this scenario the GE-SPE System at $\$ 150$ $/ \mathrm{KW}$ is driven by off-peak nuclear power costing $7.86 \mathrm{mills} /$ $\mathrm{KWh}$ (fuel and O\&M costs only). The hydrogen produced was costed at $\$ 5.61$ per million Btu. Comparing this cost to the costs generated in IVa (i.e., \$3.97 per million Btu using spinning reserve) the effect of decreasing the plant factor on amortizing the capital investment of the electrolyzer can be seen. The plant factor drops from .9 to .33, and the production cost increases from $\$ 3.97$ to $\$ 5.61$ per million Btu. It should be pointed out that the capital costs used in this work-up are projected R\&D goals and should be viewed as such.

This scenario of using off-peak electricity to generate hydrogen (i.e., turning base load hydrocarbon or nuclear fuel into a form suitable for use to power peaking turbines) has attractive qualities to the utilities. Particularly, one would expect those utilities where natural gas is not available for peaking purposes to be interested.

A study has been made by PSG\&E [Ref. 9] which attempts to evaluate the present and future off-peak power resources available in the United States. One of their major conclusions was the adequate amounts of off-peak power from base-load generating units on the utility system were available. A typical amount of this off-peak energy was 10 percent of the annual energy output produced by the utility to supply its customers demand. However, approximately $1 / 4$ to $1 / 2$ of this energy is available on weekends. Some kind of storage strategy for the hydrogen would be required in order to use this hydrogen for the weekday peaking service. Additionally the production of hydrogen would have to compete with other energy storage technologies for use at this off-peak power resource.

e. An Evaluation of the Use of Hydrogen As A Supplement to Natural Gas. This study focuses on the GE-SPE electrolysis technology. This committee was called together to assess mid-term commercial application of the use of hydrogen. They concluded that an advanced electrolyzer technology is required to make mid-term commercialization feasible. Detailed studies were carried out to evaluate the 
potential GE-SPE electrolyzer costs and efficiencies. The values they obtained and adopted are:

GE-SPE Cost Elements
Power conversion \& switchgear
Electrolysis modules
Other process equipment
Installation costs
Offsites
Contingency

$\$ / K M(t n)$

$\$ 45 / \mathrm{KW}$

$\$ 20 / \mathrm{KW}$

$\$ 23 / \mathrm{KW}$

$\$ 22 / \mathrm{KW}$

$\$ 15 / \mathrm{KW}$

$\$ 25 / \mathrm{KW}$

$\$ 150 / \mathrm{KW}$

These costs are for a plant located in the Northeast United States in 1985 (1975 $\$$ ) with output pressure of 450 psig.

\section{Study Projection V}

This study was prepared by the "ad hoc committee on the use of hydrogen for natural gas supplementation." It assumes that by 1985 a GE-SPE electrolysis system with an output capacity of $5 \mathrm{MW}$ ( $1.25 \mathrm{MSCF} / \mathrm{SD}$ ) will be commercially available for $\$ 150 / \mathrm{KW}$ installed. We have presented production costs of $\$ 10.40$ per million Btu when electricity is available at $27 \mathrm{mills} / \mathrm{KWh}$. The energy costs amount to $\$ 8.71$ per million Btu, 85 percent of the total production costs. This provides an interesting comparison, because of the close agreement of the results with the projections generated in the BNL study IVd. The ad hoc committee in this report does not endorse any particular cost of electricity in the year 1985. Hydrogen production costs are presented in the report parametrically so that the individual user can choose his own cost of electricity and plant factor. Some additional results of the study are presented below:

\begin{tabular}{llllc} 
Column Number & \multicolumn{1}{c}{1} & 2 & 3 & 4 \\
Annual Plant Factor & 0.90 & 0.45 & 0.45 & 0.45 \\
$\begin{array}{l}\text { Electricity Cost } \\
\quad \text { (mills/KWh) }\end{array}$ & 1.0 & 6.0 & 8.0 & 11.0 \\
Hydrogen Cost (\$/Btu) & 4.93 & 4.59 & 5.27 & 6.27
\end{tabular}

f. Hydrogen Energy From Small Falling Water Facilities At Existing Dams. This study was performed as a result of the recent interest in developing and redeveloping the nation's hydropower potential at existing small dams around the country. Low-head hydropower is renewable and environmentally benign, and hence is a desirable source of energy. Because of the remote nature of some of these sites and the general problem of integrating small generators into the existing electric utility grids where the energy could be used, a study was initiated to determine: 
- The available energy at small non-hydropower dams in the U.S.

Hydrogen production costs at these sites.

The approach of this study is similar to Study III in that a conceptual design for a complete electrolytic facility was performed. The optimum design was determined to consist of the following three elements:

$$
\begin{aligned}
& \text { - a low-head turbine to produce mechanical power } \\
& \text { - a conventional d.c. generator } \\
& \text { - GE-SPE electrolyzer circa } 1980 \text {. }
\end{aligned}
$$

The use of the d.c. generator eliminates the need for a.c. power-conditioning equipment usually added into the capital cost of the electrolyzer. The authors obtained system performance characteristics and installed capital costs directly from General Electric in Wilmington, Massachusetts. Capital costs for the generators and turbines were obtained from manufacturers' quotes and estimates.

The two major parameters in the cost of the hydrogen produced were "head of water" available and plant capacity. For any particular "head of water" the hydrogen production cost increased steadily as the plant capacity in MW's decreased. Correspondingly, for any particular plant capacity, hydrogen production costs increase as the "head of water" available decreases. These results are well within current knowledge on the economics of scale of hydro plants in general and are, no doubt, one of the major reasons why these sites are still undeveloped to date. The range of production costs were $\$ 5-\$ 30$ per million Btu produced depending on, as was said previously, the "head of water" available and the plant capacity that can be installed at the site. Two representative cases are abstracted to illustrate some of the economies expected if such sites were developed.

\section{Site Parameters}

5 MW Low-head Hydro

IVa Turbine with dc generator \& GE-SPE System 86 feet of head available

$2 \mathrm{MW}$ on-hand hydro

IVb turbine with dc generator and GE-SPE System

86 feet of head available.

\section{Hydrogen Costs}

$\$ 5$ per million Btu

$\$ 7.50$ per million Btu 
The study estimated that the total available energy at existing non-hydro dams in the U.S. was 27,000 MWe peak, producing annually 85 billion $\mathrm{KWh}$ of electric energy which is equivalent to (at $90 \%$ efficiency) 2.1 x $103 \mathrm{mil}$ lion Btu's of hydrogen per year. No breakdown was given as to how much of this resource was available at which "head of water" and plant capacity.

3. Hydrogen through Electrolysis vs. Hydrogen from Natural Gas

Figure III-8 compares the costs of producing hydrogen through G.E.'s SPE electrolysis and through steam reforming of natural gas. The basic data are taken from the Exxon study [Ref. 1], but with comparisons made for alternative prices of electricity and natural gas. Hydrogen produced through electrolysis appears cost competitive for scales of use below one million cubic feet per day. Since the economic competitiveness of producing hydrogen through electrolysis will depend on the availability of low-cost electricity, the two major sources generally considered for lowcost electricity -- nuclear power plants and hydroelectric power - - are considered below.

off-peak or spinning reserve power from nuclear generating plants has been considered a major source of lowcost electricity. Recent estimates have put the cost of generating electricity in nuclear power plants in 1977 at 1.5 cents/KWh, as compared to 2 cents/KWh from coal, and 3.9 cents/KWh from oil. Since these costs include capital and interest as well as fuel and operating and maintenance costs, it is clear that off-peak power from nuclear plants would be low cost. The major question, however, is the availability of the off-peak power.

A study by Public Service Electric and Gas suggested that the off-peak nuclear energy available as a percentage of total system energy produced increased markedly once nuclear capacity on the system exceeded 30 percent of total system capacity. Recent projections, however, show that nuclear capacity will not reach 30 percent until the late $1990^{\prime} \mathrm{s}$. A report by the Federal Energy Regulatory Commission, based on projections provided by the nine U.S. regional electric reliability councils, shows nuclear capacity being 29.8 percent of total capacity in 1996. Similarly, a projection of capacity mix by Electrical World shows nuclear capacity as about 29 percent of total capacity in 1995. A report by the Energy Information Administration suggests that $380 \mathrm{GW}$ of installed nuclear capacity is the "maximum achievable capacity" by 2000. The PSE\&G study showed that the amount of off-peak nuclear energy available is only 


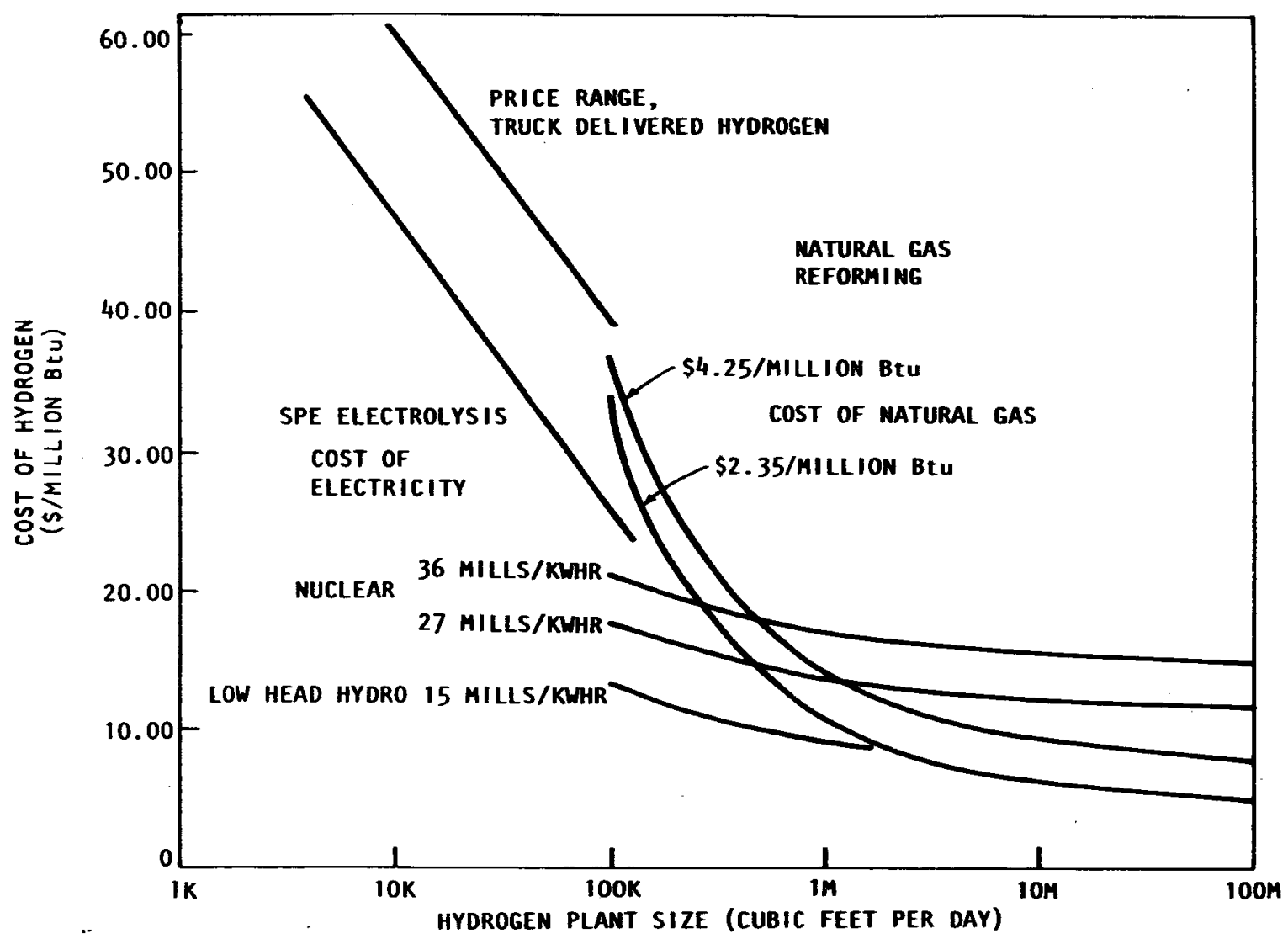

Figure III-8. Comparative Costs of Producing Hydrogen Advanced Electrolysis vs. Natural Gas Reforming 
about 0.2 percent of total energy produced on a system when nuclear capacity is 30 percent of total system capacity. Accordingly, these projections indicate that the availability of off-peak nuclear power will in general be limited. However, some utilities, particularly in the northeast and mid-atlantic regions, may have a higher percentage of nuclear capacity which could provide off-peak power.

While hydroelectric power is a second major source of low-cost electricity, few major hydroelectric sites remain available in the U.S. However, the recent study by IGT/PGW identified a significant number of small capacity falling water sites which could be used for the production of hydrogen. A probable range of 0.15 to 0.25 quads was estimated for the hydrogen which could be produced from these sites, with about one-third of this amount being attainable from sites in the northwest. Reference to Table II-7 will show that hydrogen supplied in these quantities from low lead hydro sites would be sufficient to meet the demand for hydrogen from specialty uses.

\section{Comparison of Alternative Technologies}

The comparative cost calculations presented in the two preceding sections do not take into account the probability that restrictions on the availability of natural gas because of declining domestic production may induce a shift to producing hydrogen by means other than the use of natural gas. Recent projections of domestic natural gas production are summarized in Table III-6, while Table III-7 shows projections (from the same studies) of gas use in the U.S.

These various projections show a widening gap between declining domestic production and increasing use. Indeed, the use of gas in the U.S. has been constrained since the early 1970's by the availability of gas supplies. In part the gap between production and use can be filled by supplements-imports, coal gasification, etc. Such supplements, however, are considerably higher in price than natural gas. Moreover, if they are not available in quantities sufficient to fill the gap between production and use, low priority customers will have their gas supplies curtailed.

In particular, gas is expected to be available for high priority uses, including critical industrial uses such as fertilizer production, heat treatment, metal finishing, baking, etc. Thus, some users producing hydrogen from natural gas will not have their gas supplies curtailed. For example, Dickson et al. point out: 
TABLE III-6. U.S. NATURAL GAS PRODUCTION

(Trillion Cubic Feet)

\begin{tabular}{|l|c|c|c|c|c|}
\hline \multicolumn{1}{|c|}{ Source } & 1977 & 1985 & 1990 & 1995 & 2000 \\
\hline \hline Phillips Petroleum & $\approx 20.0$ & -- & -- & $\approx 9.54$ \\
EIA & 19.6 & $15.1-18.9$ & $12.8-17.7$ & - & - \\
Exxon & $\approx 19.0(1975)$ & 15.0 & 14.2 & - \\
Shel1 & $19.2(1975)$ & 21.5 & 12.9 & - & - \\
IGT & $18.8(1978)$ & 17.2 & 21.7 & 14.3 \\
EPRI & 18.5 & $19.6(1986)$ & $19.41(1989)$ & 18.65 & $15.96(2001)$ \\
NEP & $19.91(1975)$ & 16.0 & 14.0 & - \\
SRI & & & - \\
A.D. Little &
\end{tabular}

TABLE III-7. U.S. USE OF GAS

(Trillion Cubic Feet)

\begin{tabular}{|c|c|c|c|c|c|}
\hline Source & 1977 & 1885 & 1990 & 1995 & 2000 \\
\hline $\begin{array}{l}\text { EIA } \\
\text { Exxon } \\
\text { She11 } \\
\text { IGT } \\
\text { EPRI } \\
\text { NEP } \\
\text { SRI } \\
\text { A.D. Little }\end{array}$ & $\begin{array}{l}20.0 \\
20.1 \quad(1975) \\
20.1- \\
20.97 \\
20.8 \text { (1976) }\end{array}$ & $\begin{array}{l}17.1-20.3 \\
18.4^{--} \\
25.7^{--} \\
22.5(1986) \\
19.6\end{array}$ & $\begin{array}{l}15.4-19.9 \\
17.0 \\
16.7 \\
27.7- \\
22.7(1989) \\
18.8\end{array}$ & $\begin{array}{l}- \\
- \\
-- \\
\overline{27.9} \\
\overline{23.4} \\
--\end{array}$ & $25.9^{--}$ \\
\hline
\end{tabular}


Although methane is becoming increasingly scarce and expensive (when not subject to federal price regulations), the priority held by ammonia producers to supplies of natural gas is second only to the priority of residential use. This priority is a direct result of the fact that about three-fourths of all ammonia is being used as an agricultural fertilizer... Moreover, as other lower-priority users of natural gas are curtailed, the lifetime of the suppliers will be extended, which will increase the likelihood that ammonia producers will continue to receive methane on a priority basis [Ref. 10].

However, others producing hydrogen from natural gas may either be curtailed or be forced to use higher priced gas supplements: Accordingly, shifts might be expected among such users to other means of producing hydrogen, particularly during the 1990's. Figure III-9 suggests that if such shifts do indeed occur, then electrolysis and coal gasification are likely to be complementary, not competitive, technologies for producing hydrogen. That is, the high ratio of capital costs to energy costs for coal gasification plants better suits them to production of large quantities of hydrogen, while the low ratio of capital costs to energy costs for electrolyzers suits them to the production of hydrogen for small scale uses.

The choice between electrolysis and coal gasification for producing hydrogen may also be affected by the regional 10cations of coal, hydro and nuclear resources. Figure III-10, showing the locations of coal and nuclear resources, suggests that electrolysis might prove attractive in the Northeast and in the West where the availability of nuclear and hydro power can compensate for the lack of coal resources. 


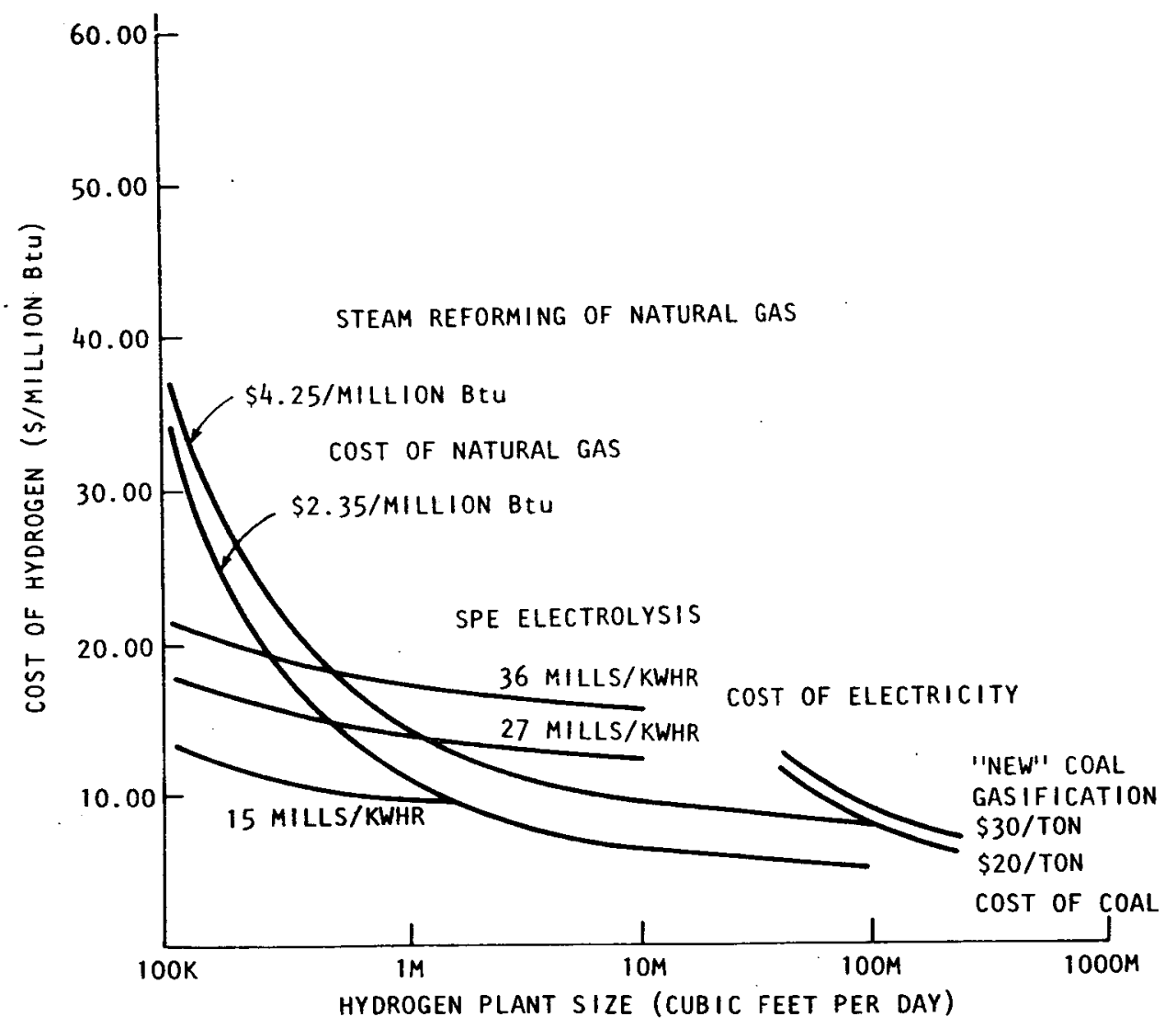

Figure III-9. Comparative Costs of Producing Hydrogen by Natural Gas Reforming, Advanced Electrolysis, "New" Coal Gasification

1980 \$ 

REFERENCES

Chapter III

1. Corneil, H.G., Heinzelmann, F.J. and Nicholson, E.W.S. Production Economics for Hydrogen, Ammonia and Methanol During the 1980-2000 Period, (Linden, New Jersey: Exxon Research and Engineering Company, 1977).

2. C.F. Braun and Co., Coal Gasification Commercial Concepts Gas Cost Guidelines, January, 1976:

3. Biederman, N.; Darrow, K., Jr.; and Konopka, A. Utilization of Off-Peak Power to Produce Industrial Hydrogen, (Chicago, IIIinois: Institute of Gas Technology for the Electric Power Research Institute, 1975).

4. Russell, J.H.; Nuttall L.J. Solid Polymer Electrolyte Water Electrolysis Development Status. Preprints of the DOE Chemical Energy Storage and Hydrogen Energy Systems Contracts Review. Nov. 16-17, 1977 Hunt Valley Maryland.

5. Fickett, A.P. and Kalhammer, F.P.; Chapter 1 "Water Electrolysis" In: Hydrogen: Its Technology and Implications Vol. 1 Hydrogen Production Technology.

6. Telephone Conversation with L.J. Nutta11, General Electric Company.

7. Edison Electric Institute, New York, N.Y., Statistical Yearbook as quoted in Statistical Abstract 1977, U.S. Department of Commerce, page 603.

8. Nuttall, L.J. Conceptual Design of Large Scale Water Electrolysis Plant Using Solid Polymer Electrolyte Technology, March 1976.

9. Public Service Electric and Gas Company, N.J Hydrogen Supplementation Evaluation Study, September 1977 for USERDA.

10. Dickson, E.M.; Ryan, J.W.; and Smulyan, M.H. The Hydrogen Energy Economy (Praeger Publishers, 1977). 
As discussed in Chapter II, hydrogen is now used primarily in chemical applications, where it is produced and consumed on site. As time passes, however, new uses of hydrogen may develop not only in chemical applications but in fuel applications as well, with the hydrogen being supplied from external sources. Projecting the growth in the use of hydrogen for these prospective uses is difficult. Unlike existing chemical applications of hydrogen, where no alternatives exist to the use of hydrogen, most of the prospective uses of hydrogen could also be met using alternative means. Consequently, the market for hydrogen will depend on the economic competitiveness of hydrogen with the alternatives.

This chapter therefore surveys possible new uses of hydrogen primarily to identify the conditions under which hydrogen could be brought into use. Based on these considerations, the potential markets for hydrogen in prospective uses are evaluated as to their probable growth and the timing for the transition to the use of hydrogen.

\section{A. Identification of Possible Uses}

Scenarios developed by JPL and by SRI provide a reference point for considering possible new uses of hydrogen [Ref. 1 and Ref. 2]. The two scenarios are roughly congruent in their broad features. In both, near term uses for hydrogen will continue to be in chemical applications. In the intermediate term, both scenarios see the possibility of hydrogen coming into use by utilities and in air transportation. The hydrogen used in utility applications (for load leveling by electric utilities and for natural gas supplementation) can be considered captive hydrogen, produced and consumed at the same site. Use of hydrogen for air transportation, however, would represent the first step to broader use of merchant hydrogen. While new industrial processes developed for the far term will probably make use of captive hydrogen, the use of hydrogen for transportation vehicles and for residential/commercial uses would considerably broaden the market for merchant hydrogen. 
While the two scenarios show broad agreement on the general pattern by which new uses of hydrogen will develop, there is some divergence on particulars. The most important example of this divergence is that SRI envisions the use of hydrogen for coal gasification (and, by implication, for other synthetic fuels) developing relatively later in time than projected in the JPL scenario. The reasoning leading to this difference, which has important implications for estimates of the size of the future market for hydrogen, is examined in the next section.

\section{B. Captive Uses of Hydrogen}

The new uses of hydrogen which the scenarios posit as being most likely to develop first -- in the production of synthetic fuels and in utility applications -- are examined in this section.

1. Hydrogen Use in Production of Synthetic Fuels

Production of the various synthetic fuels -- substitute natural gas, crude oil from coal or oil shale, methanol, etc. -- requires significant amounts of hydrogen. Various estimates of the total hydrogen required for the production of synthetic fuels are summarized in Table IV-1. Differences among the estimates are mainly attributable to differences in the assumed rates at which synthetic fuels will penetrate the market.

With currently proposed technologies for producing synthet1c fuels, the hydrogen required is produced and consumed within the synthetic fuels plant. Calculations of total hydrogen requirements therefore overstate the market avallable for penetration by new hydrogen production technologies. Thus, the relevant market for hydrogen to consider 1s that which can be supplied from sources external to the plant. Indeed, use of externally-supplied hydrogen would be expected to improve the efficlencies with which synthetic fuel might be produced from coal or oll shale.

Dickson, et al. have presented an a priort argument however, against the economic merits of using outside hydrogen in synthetic fuels production:

This proposed application of merchant hydrogen, however, is not very likely to be realized. In the first place, it would prove less efficient to use nuclear power to produce hydrogen as a distinct intermediate product than to use the nuclear power for 
TABLE IV-1. SUMMARY OF HYDROGEN FORECASTS SYNTHETIC FUELS

(In Quads)

Study

Synfuel

$\underline{1985} \quad \underline{2000}$

Comments

Hydrogen Tomorrow

(JPL)

Low (Reference)

Oil shale

Coal Gasification

$0.025 \quad 0.100$

N11 0.507

Coal Iiquefaction

Ni1 1.100

High (Expanded) 011 Shale

Nil Nil

Coal Gasification

$0.484 \quad 3.388$

Coal Liquefaction

0.016

4.069

Hydrogen Assessment (BNL)

Oil Shale Coal Gasification Coal Liquefaction
0.037
0.16
$0.11 \quad 1.63$
$0.023 \quad 0.23$

Based on ERDA projections.

Exxon

Mineral Facts and Problems Probable

Oil Shale Coal Gasification Coal Liquefaction

0.237

2.275

0.354

Low

011 Shale

0.036

0.062

Coal Gasification

0.185

Nil

1.140

Coal Liquefaction

0.195

High

011 Shale

0.312

5.690

Coal Gasification

Coal IIquefaction

0.975 
process heat in the gasification or liquefaction process. Second, if nuclear-derived hydrogen could be purchased for the process more cheaply than it could be produced from the coal, it would make little economic sense to manufacture high-cost synthetic methane when low-cost. hydrogen was available as a competitor. Thus, it appears that although coal gasification and iiquefaction technologies will eventually be deployed and will require hydrogne, the hydrogen will be derived from the energy of coal itself. Similar conclusions apply to the hydrogenation steps in oil shale processing and the production of methanol from coal and various waste materials [Ref. 2].

IGT also evaluated the use of outside hydrogen for production of synthetic fuels. Although calculations showed that the use of outside hydrogen would increase the yields of methanol, SNG and gasoline produced from coal and would provide capital savings through the elimination of several items of equipment, IGT concluded on the basis of calculated break-even costs that:

In spite of all this, however, it is highly unlikely that the outside hydrogen can be supplied cheaply enough to compete with captive production. ... Methanol is the most likely coal process to be able to utilize a utility stream of hydrogne, but current coal prices and expected hydrogen prices still make captive production the cheapest method [Ref. 3].

Thus, these arguments indicate that even early commerclalization of synthetic fuels technologies will not establish conditions appropriate for the use of externally supplied hydrogen.

\section{Utility Use of Hydrogen for Load Leveling}

Dickson, et al., in the SRI technology assessment of the hydrogen energy economy concluded that: "By far the most attractive use of hydrogen in utilities is in the form of load leveling [Ref. 2]." Development of this use would enhance the market for electrolyzers, complementing the rather thin market which now exists. The use of hydrogen for this purpose, however, depends on a number of conditions.

These conditions are revealed in the JPL calculation to show the amount of hydrogen which could be produced for load leveling in a scenario illustrating expanded production of hydrogen. The captive hydrogen demand for load leveling can 
be calculated as a product of nuclear base load capacity, the percentage of this capacity available off-peak, and the percentage of the power generated off-peak which could be stored and reused by a hydrogen based system (taking into account also the efficiencies of the generator and the electrolyzer). On the assumptions that nuclear capacity would provide about 45 percent of total electric supply in the year 2000, that 10 percent of the nuclear generated power would be available off-peak and that hydrogen systems could take 25 percent of this total, JPL calculated a captive hydrogen demand for this purpose of 0.85 quads in the year 2000 .

From current perspective, these assumptions now appear optimistic. In particular, the projections for installed nuclear capacity (discussed in the previous chapter) indicate that U.S. nuclear capacity will not reach 30 percent of total capacity until the late 1990's. Moreover, the offpeak energy produced on an electric utility system can of course be stored by other methods now in existence or being developed. Calculating the percentage of the off-peak energy which could be claimed for hydrogen storage systems therefore entails a comparison of the capital and operating costs of the alternative storage systems. Such calculations are the subject of other studies and are not examined here.

The same requirement for a comparison to alternatives arises in considering the possible use of electrolyticallyproduced hydrogen to supplement natural gas supplies. The basic comparison here is between the cost of producing the hydrogen and the costs of other possible supplements, including SNG, imported LNG, etc. The Hydrogen Supplementation System Evaluation Study performed by Public Service Electric and Gas [Ref. 4] suggests that producing hydrogen though electrolysis will be cost competitive with gas supplements for some utilities. However, it would appear that the essential condition is that the utility have a high percentage of nuclear capacity which could provide off-peak power. As discussed previously, current projections suggest that nuclear capacity to provide off-peak power will be limited for most utilities. 


\section{Fuel Applications of Hydrogen}

While the use of hydrogen in fuel applications can be conjectured, the timing on and the extent of such uses remain unclear. Hydrogen as a fuel will be competing with other fuels, and the rate at which the costs of producing hydrogen are lowered relative to the costs of other fuels will be a primary determinant of how rapidly the use of hydrogen as a fuel increases.

Air transportation is generally considered one of the first fuel applications in which hydrogen may become cost competitive. Nevertheless, a comparison of the JPL and SRI scenarios illustrates the difficulties which arise in projecting the use of hydrogen for fuel applications. In considering the possibilities for expanded use of hydrogen, the JPL study suggested that:

For hydrogen-fuel airplanes, the transition would probably be gradual and could be led by the military sector where the potential performance advantage of using hydrogen fuel can be exploited for military purposes. In this context, conversion of military aircraft to hydrogen has been assumed to occur by the year 2000 [Ref. 1].

Contrasted to that is the observation of Dickson, et al., that:

At present, however, DOD exhibits little interest in hydrogen-fueled alrcraft, probably because of worldwide logistics problems with hydrogen and the difficulty of designing a high-performance hydrogen-fueled fighter. It would be awkward to fuel jet transports on hydrogen, but jet fighters on conventional fuel, because that would require a parallel fuel system. Should the DOD decide not to fly hydrogen-fueled aircraft for any mission, then the manufacturer's cost of development of a civilian airplane would rise, since there would be no appreciable technology transfer. This would be an important consequence for the future of hydrogen-fueled civilian aviation [Ref. 2].

Since the expression of DOD's disinterest in hydrogen-fueled aircraft was conveyed to Dickson et al. by a representative of the DOD Office of the Director of Defense Research and Development, the backing for their scenario appears stronger. 
Given that a transition to hydrogen-fueled aircraft would have to be led by the civilian aviation sector, Dickson et al. suggest the possibility that:

A planned implementation schedule could probably enable the hydrogen-fueled system to supplant most of the long-haul jet-fueled systems within a decade once deliveries began. The scenario might proceed as follows:

1. In 1976 public and private discussions about the transition might begin.

2. In 1980 the decision to produce both an airplane (perhaps selected in a government competition) and fuel would be made.

3. In 1995 the first liquid-hydrogen-fueled aircraft would be delivered to airlines, and fuel would be available at four of the most separated major air travel hubs...

4. Between 1995 and 2000 one new airport could be added to the network every six months within the United States, and facilities for fueling would be installed at major overseas airports ... [Ref. 2]

Current evidence suggests that the probability of this scenario developing in the remainder of this century is very low. In particular, major airframe and engine manufacturers have now committed to developing a new generation of jetfueled aircraft. The development costs of this effort will be such as to preclude serious consideration of developing a hydrogen-fueled aircraft without substantial government assistance. Whether the benefits of hydrogen fueled aircraft are sufficient to justify such assistance appears moot. Accordingly, a transition to hydrogen-fueled aircraft beginning much before the year 2000 seems improbable.

If hydrogen is not used to fuel aircraft before the year 2000 , the use of hydrogen in other fuel applications will not be realized, if at all, until several decades into the 21 st century. Because hydrogen will be competing with a variety of other fuels, growth in its use as a fuel can only be addressed by considering the conditions on interfuel substitutions. Models of interfuel competition have been developed by Brookhaven National Laboratory and by SRI International, and results from reported simulations of those models suggest limited use of hydrogen as a fuel before 2020 . 
The conclusions drawn from such analytical models reflect of course no more than the assumptions on which the model is run. In particular, scenarios prepared for the Workshop on Societal Aspects of Hydrogen Energy Systems using the Brookhaven model reflect the assumptions that the economics of producing hydrogen are unfavorable compared to production of low-Btu gas, high-Btu gas and coal liquids. The SRI model similarly draws the conclusion that production of hydrogen from coal is uneconomical on the assumptions that the costs of transporting the input coal and the lowBtu hydrogen produced are higher than for conversion and transporting of high-Btu gas or liquids produced from coal.

Such assumptions are based on current evaluations of hydrogen production technologies and do not account for the possibility that the penetration of new hydrogen production technologies into existing markets based on chemical applications could provide learning experience which would enhance the probabilities for use of these technologies in fuel applications. That is, there is less competition for hydrogen in chemical applications, and the early use of hydrogen for such uses may provide means for reducing the costs of production which would permit hydrogen to compete in fuel applications. 


\section{REFERENCES}

\section{Chapter IV}

1. Kelley, J. and Laumann, E. Hydrogen Tomorrow, Demands and Technology Requirements (Pasadena, Cal.: Jet Propulsion Laboratoty, 1975).

2. Dickson, E.M.; Ryan, J.W.; and Smulyan, M.H. The Hydrogen Energy Economy (N.Y.: Praeger Publishers, 1977).

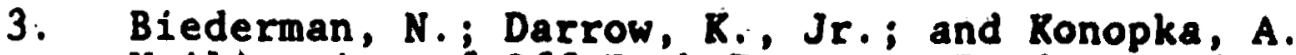

Utilization of Off-Peak Power to Produce Industrial Hydrogen (Chicago, Illinois: Institute of Gas Technology for EPRI, 1975).

4. Ku, W.S., et al., Hydrogen Supplementation System Evaluation Study (Public Service Electric and Gas, September, 1977). 